medRxiv preprint doi: https://doi.org/10.1101/2021.08.18.21262243; this version posted August 23, 2021. The copyright holder for this preprint (which was not certified by peer review) is the author/funder, who has granted medRxiv a license to display the preprint in perpetuity. It is made available under a CC-BY-NC-ND 4.0 International license .

PRECURSORS OF BILINGUAL LITERACY DEVELOPMENT

\title{
Early Precursors of Literacy Development in Simultaneous Bilinguals: A Systematic Review and Meta-Analysis
}

\author{
Insiya Bhalloo ${ }^{1,2}$, and Monika Molnar ${ }^{1,2}$ \\ ${ }^{1}$ Department of Speech-Language Pathology, University of Toronto \\ ${ }^{2}$ Rehabilitation Sciences Institute, Faculty of Medicine, University of Toronto
}

\section{Acknowledgements:}

We thank Kai Ian Leung, for her help with screening papers, along with University of Toronto librarians, Chad Crichton, Erica Nekolaichuk and Glyneva Bradley-Ridout, for helping with the database and search terms selection.

This project was supported by a Canada Graduate Scholarship - Master's (CGS-M) awarded to Insiya Bhalloo by the Social Sciences and Humanities Research Council of Canada (SSHRC:

771-2019-0057).

\section{Author Note:}

Correspondence regarding this article may be addressed to Insiya Bhalloo, Department of Speech-Language Pathology, Rehabilitation Sciences Institute, Faculty of Medicine, University of Toronto (500 University Avenue, Toronto, ON, M5G 1V7). Phone: +1 416-946-8638. Email: insiya.bhalloo@mail.utoronto.ca

\section{Disclosures:}

No conflicts of interest, financial or otherwise, are declared by the authors. 
medRxiv preprint doi: https://doi.org/10.1101/2021.08.18.21262243; this version posted August 23, 2021. The copyright holder for this preprint (which was not certified by peer review) is the author/funder, who has granted medRxiv a license to display the preprint in perpetuity.

It is made available under a CC-BY-NC-ND 4.0 International license .

\title{
PRECURSORS OF BILINGUAL LITERACY DEVELOPMENT
}

\begin{abstract}
Several literacy precursors have been identified in monolingual English-speaking children; however, it is unclear whether the same precursors are also associated with literacy development in bilingual children. Purpose: We examine whether in simultaneous bilingual children: (i) code-related, oral-language, and domain-general cognitive literacy precursors have been utilized - similar to monolingual children; (ii) other types of precursors have been identified; (iii) code-related, oral-language, domain-general cognitive, or other types of literacy precursors are associated with word/non-word and/or text-level reading skills; in (a) one or (b) both spoken languages; (iv) the type of literacy outcome measure, and (v) language background measure influence performance on emergent literacy skills. Method: We examined reported statistical associations, between a given literacy precursor and outcome measure, and conducted a meta-analysis examining specific code-related and oral-language precursors in relation to word/non-word reading and/or text reading comprehension. Results: Apart from semantic awareness, all code-related, oral-language, domain-general cognitive and eight additional identified precursors were significantly associated with reading in simultaneous bilinguals. However, these precursors were predominantly assessed only in English, or English in addition to a heritage language. Phonological awareness and vocabulary emerged as commonly-assessed precursors consistently associated with reading. Conclusions: Particularly, these code-related and oral-language skills may be used as precursor screening tools in simultaneous bilinguals, across heritage and societal languages. Future research should develop language-specific precursor screening tools and investigate the reliability of non-linguistic precursors, to address the evident English assessment bias and support biliteracy development across spoken languages.
\end{abstract}


medRxiv preprint doi: https://doi.org/10.1101/2021.08.18.21262243; this version posted August 23, 2021. The copyright holder for this preprint (which was not certified by peer review) is the author/funder, who has granted medRxiv a license to display the preprint in perpetuity.

It is made available under a CC-BY-NC-ND 4.0 International license .

\section{PRECURSORS OF BILINGUAL LITERACY DEVELOPMENT}

\section{Background}

Globally, 56\% of children do not meet age-appropriate reading levels (United Nations Educational, Scientific and Cultural Organization [UNESCO], 2017). It is important to identify reliable precursors of literacy to facilitate early screening of reading difficulties, thereby mitigating resulting academic and socio-economic ramifications in all children - both monolingual and bilingual (Ritchie \& Bates, 2013). Literacy precursors are linguistic and cognitive skills, emerging during preschool age, that facilitate reading acquisition (Birgisdottir et al., 2020; Schaars et al., 2019). Most research has focused on English-speaking monolinguals; however, approximately half of children worldwide are bilingual (e.g., Grosjean, 2010; Ryan, 2013). This review problematizes such a dominant focus on English-monolingual literacy development by emphasizing assessment across home/heritage ${ }^{1}$ and school/societal ${ }^{2}$ languages.

Research has investigated literacy precursors via various reading models, including Simple View of Reading (SVR; Castles et al., 2018), Dual Route Model of Reading (Ripamonti et al., 2014), Linguistic Interdependence Hypothesis (LIH; Kim \& Piper, 2019), and Script Dependent Hypothesis (SDH; Geva \& Siegel, 2000). Apart from $L I H$ and SDH, most models are based on European alphabetic languages, and primarily English monolinguals (Daniels \& Share, 2018). The $L I H$ and $S D H$ demonstrate influences of home-language vocabulary on schoollanguage reading, and orthographic features — whether shared or disparate — on cross-language literacy skill transfer (Bialystok et al., 2005). These bidirectional cross-language effects

\footnotetext{
${ }^{1}$ The main language spoken within the home, in a country where the heritage language is not an official language.

${ }^{2}$ The main language of education and communication outside the home, which is considered an official language in the child's country of residence.
} 
medRxiv preprint doi: https://doi.org/10.1101/2021.08.18.21262243; this version posted August 23, 2021. The copyright holder for this preprint (which was not certified by peer review) is the author/funder, who has granted medRxiv a license to display the preprint in perpetuity.

It is made available under a CC-BY-NC-ND 4.0 International license .

\section{PRECURSORS OF BILINGUAL LITERACY DEVELOPMENT}

emphasize assessing and supporting literacy development, via language-specific ${ }^{3}$ precursor screening tools, across spoken languages (Kim \& Piper, 2019).

In monolingual English-speaking children, systematic reviews and correlational metaanalyses identified nine precursors of word/non-word reading and text reading comprehension which are listed below (García \& Cain, 2014; Hjetland et al., 2017; National Early Literacy Panel [NELP], 2008):

Code-related skills include phonological awareness, letter knowledge, and serial recall. These early skills enable acquisition of systematic relationships between oral and written language, and the alphabetic principle ${ }^{4}$. According to the $S V R$, these skills (i.e., decoding; D) and oral language comprehension (LC) together contribute to reading comprehension (RC; Castles et al., 2018). Across orthography type, preschool and Grade 1 code-related skills are associated with early decoding (D) and later fluent word/non-word recognition which, followed by oral language (LC), contribute to Grade 2 RC (Caravolas et al., 2019; Muter et al., 2004).

Phonological awareness is an important precursor (McBride-Chang et al., 2004), influenced by orthography type and the relationship between phonological grain size units ${ }^{5}$. As compared to the contribution of phonemic awareness to word recognition in alphabetic languages such as English (Ellis \& Hooper, 2001), syllable and onset-rime awareness demonstrate strong correlations with

\footnotetext{
${ }^{3}$ Based on language-specific phonological/orthographic properties.

${ }^{4}$ Awareness of the predictable relationship between individual speech sounds (e.g., phonemes) and the corresponding code (e.g., graphemes/symbols), such as phoneme-letter associations in English.

${ }^{5}$ According to the Psycholinguistic Grain Size Theory, phonological grain sizes are the most accessible and consistently represented (onto orthographic units such as letters or characters) speech sound units, based on language-specific orthographic characteristics (Ziegler \& Goswami, 2005). These speech sounds include phonemes (which are mapped onto letters in alphabetic languages such as English), syllables (mapped onto characters in morphosyllabic/logographic and alpha-syllabic languages such as Chinese or Tamil, with larger grain sizes), or morphemes.
} 
medRxiv preprint doi: https://doi.org/10.1101/2021.08.18.21262243; this version posted August 23, 2021. The copyright holder for this preprint (which was not certified by peer review) is the author/funder, who has granted medRxiv a license to display the preprint in perpetuity.

It is made available under a CC-BY-NC-ND 4.0 International license .

\section{PRECURSORS OF BILINGUAL LITERACY DEVELOPMENT}

character recognition in morpho-syllabic/logographic languages such as Chinese (Ruan et al., 2018). As children acquire language-specific linguistic structures and sound-grapheme correspondences, word decoding becomes automatic. This enables dual sub-lexical (i.e., phonological processes for decoding unfamiliar words) and lexical (i.e., whole-word processes for recognizing high-frequency words) reading routes (see Dual Route Model of Reading) — with the lexical route predominantly facilitating reading in morpho-syllabic languages (Tong \& McBride, 2017; Yeong et al., 2013).

Oral language skills involve understanding and producing spoken language, including vocabulary and grammar (i.e., morphological and syntactic awareness). Oral language skills contribute to early decoding at Grade 1-2 levels, and later fluent word/non-word and character recognition (Foorman et al., 2015; Hulme at al., 2019). In monolingual English readers, oral language (LC) and word/non-word reading/speed (D) have been evidenced as the most significant contributors of RC (SVR) across elementary and secondary grades, compared to nonverbal reasoning and working memory (Tighe et al., 2015; see next section). Oral language (LC) and character recognition skills also facilitate RC in monolingual Chinese primary-level readers (Dong et al., 2020; Yan et al., 2020).

Domain-general cognitive skills include memory and non-verbal intelligence which involve non-language-specific reasoning. Kindergarten domain-general cognitive skills are consistent contributors to reading and passage comprehension in English and Chinese monolinguals, across primary and secondary grade levels (Adlof et al., 2010; Yang \& Qiao, 2021). Code-related and domain-general cognitive skills also typically show a correlation (Oakhill \& Kyle, 2000). 
medRxiv preprint doi: https://doi.org/10.1101/2021.08.18.21262243; this version posted August 23, 2021. The copyright holder for this preprint (which was not certified by peer review) is the author/funder, who has granted medRxiv a license to display the preprint in perpetuity.

It is made available under a CC-BY-NC-ND 4.0 International license .

\section{PRECURSORS OF BILINGUAL LITERACY DEVELOPMENT}

\section{Review Objectives}

This review and meta-analysis examine literacy precursors used for assessing typicallydeveloping and hearing simultaneous bilingual children (i.e., exposed to both languages before 3 years, prior to learning to read in kindergarten; Patterson, 2002). Because differences between monolinguals and bilinguals in oral language and domain-general cognitive skills have been observed (Blom et al., 2014; Kuo et al., 2016), it could lead to differential emergent literacy development. While there is valuable literature on sequential bilinguals and second-language learners (e.g., August \& Shanahan, 2006; Lesaux \& Geva, 2006), this review focuses on simultaneous bilinguals, a considerable segment of the bilingual population, without age of acquisition (AoA) influences. As this paper focuses on existing pre-literacy skills, we included assessment studies only. Specifically, our goals are to examine whether:

(i) Code-related, oral language, and domain-general cognitive precursors have been assessed in relation to reading in simultaneous bilingual children, similar to monolinguals.

(ii) Literacy precursors, in addition to these skills, have been identified and assessed in relation to reading in simultaneous bilinguals.

(iii) Code-related, oral language, domain-general cognitive, and additional identified literacy precursors are associated with word/non-word and/or text-level reading skills, in (a) one or (b) both spoken languages.

(iv) Type of outcome measure (e.g., word, non-word and text reading accuracy, speed and comprehension) influences precursor-outcome associations.

(v) Language background (type and frequency of language exposure) influences performance on literacy precursors and outcome measures. 
medRxiv preprint doi: https://doi.org/10.1101/2021.08.18.21262243; this version posted August 23, 2021. The copyright holder for this preprint (which was not certified by peer review) is the author/funder, who has granted medRxiv a license to display the preprint in perpetuity.

It is made available under a CC-BY-NC-ND 4.0 International license .

\section{PRECURSORS OF BILINGUAL LITERACY DEVELOPMENT}

\section{Eligibility Criteria}

\section{Methods}

The database search was based on PICO framework (Richardson et al., 1995): Population (i.e., typically-developing and hearing simultaneous bilinguals, $\leq 12$ years), Intervention (i.e., literacy precursor assessed), Comparison (no specified controls), and Outcome (i.e., readingbased outcome measure assessed).

\section{Information Sources}

After consulting linguistics and speech-language pathology librarians, we entered search terms (Table 1, Appendix A) into four databases: Linguistics and Language Behavior Abstracts (LLBA), Educational Resources Information Center (ERIC), MLA International Bibliography and PsycINFO (ProQuest), indexing peer-reviewed literature. We conducted the most up-to-date database search on August $16^{\text {th }}, 2021$ and did not specify publication year limits. These searches included peer-reviewed and gray literature, and callouts for unpublished research.

\section{Search}

The nine literacy precursors were individually searched with the two outcome measures, to find studies discussing at least one precursor in relation to word/non-word reading and/or text reading comprehension. A general search was conducted to identify additional precursors unique to bilingual children (see Supplemental File 1, Appendix A for database search syntax). Tables 2 and 3 indicate search strategy and terms (Appendix A). We also conducted a Google Scholar and manual reference search of included studies, and excluded non-primary and case studies, to identify additional relevant studies (Figure 1, Appendix A).

\section{Study Selection}

Two independent reviewers screened studies based on following inclusion, exclusion and critical appraisal criteria at title/abstract and full-text levels. A third reviewer was also consulted. 
medRxiv preprint doi: https://doi.org/10.1101/2021.08.18.21262243; this version posted August 23, 2021. The copyright holder for this preprint (which was not certified by peer review) is the author/funder, who has granted medRxiv a license to display the preprint in perpetuity.

It is made available under a CC-BY-NC-ND 4.0 International license .

\section{PRECURSORS OF BILINGUAL LITERACY DEVELOPMENT}

\section{Inclusion Criteria}

1. Assessed existing precursor skills in relation to reading-based literacy outcome measures (e.g., word/text-level reading or comprehension);

2. Assessed precursors in typically-developing and hearing simultaneous bilinguals and/or multilinguals $\leq 12$ years, and/or included age-matched typically-developing bilingual controls; 3. Assessed simultaneous bilinguals who: were born or immigrated prior to 3 years to a country where heritage language was not an official language and had sufficient exposure to heritage language at home and school/societal language in wider community, even if societal language was not home language; or were exposed to both as home languages. We verified full texts of abstracts on second language learners, due to interchangeable use in bilingualism literature.

\section{Exclusion Criteria}

1. Non-primary (e.g., reviews) and case studies;

2. Non-English studies with inaccessible translations;

3. Studies on bimodal bilingual populations (i.e., with signed-spoken language combinations);

4. Literacy precursor intervention studies, that did not also assess existing precursor skills;

5. Studies only analyzing precursors in relation to other precursors, not reading outcomes;

6. Studies only assessing non word, sentence or passage-level reading measures (e.g., letter naming, spoken word recognition, spelling and/or writing);

7. Studies not separating non-typically developing, deaf and/or sequential bilinguals ${ }^{6}$ or second language learners ${ }^{7}$ from typically-developing and hearing simultaneous bilinguals in analyses.

\footnotetext{
${ }^{6}$ Who acquired the second language (L2) at school between the age of 4-6 in an L2-majority country.

${ }^{7}$ Who acquired the L2 at school after the age of 6 in a non-L2 majority country.
} 
medRxiv preprint doi: https://doi.org/10.1101/2021.08.18.21262243; this version posted August 23, 2021. The copyright holder for this preprint (which was not certified by peer review) is the author/funder, who has granted medRxiv a license to display the preprint in perpetuity.

It is made available under a CC-BY-NC-ND 4.0 International license .

\section{PRECURSORS OF BILINGUAL LITERACY DEVELOPMENT}

\section{Critical Appraisal of Studies}

To account for risk of bias, included studies met relevant criteria from an adapted Critical Appraisal Checklist for Quasi-Experimental Studies (Joanna Briggs Institute, 2017):

1. Clear Cause and Effect: Examined whether precursors were associated with outcomes;

2. Reliable Assessment and Outcome Measures: Described literacy assessment measures;

3. Appropriate Statistical Analyses: Used appropriate statistical tests;

\section{Description of Follow-Up Procedures in case of Participant Attrition during Longitudinal}

Studies: Accounted for participant attrition.

\section{Additional Criteria - Sufficient Language and Socio-Economic Status (SES) Background:}

Specified adequate language and demographic background information, including AoA and/or language proficiency, and SES (see Data Items). This is because type of bilingual experience and SES influence emergent literacy skills (Meir \& Armon-Lotem, 2017; Wood et al., 2018).

\section{Data Items}

After study screening (see Table 4, Appendix A for included studies), data items were extracted (Table 5 and Supplemental Excel Table 1, Appendix A): study citation information (i.e., author names, publication year, database, in-text citation and reference), participant demographic characteristics (i.e., sample size, number and type of participant groups, age at evaluation, gender, place of birth or age at immigration, and language status in country of assessment), language background (e.g., spoken language combinations, AoA, and degree/duration of language exposure), proficiency measures (e.g., parent/teacher-completed questionnaires, classroom observations, child interviews, oral language comprehension/production tasks, reading assessments), parental SES (i.e., parental income, education, and home/school neighbourhood), assessed literacy precursor and outcome measures 
medRxiv preprint doi: https://doi.org/10.1101/2021.08.18.21262243; this version posted August 23, 2021. The copyright holder for this preprint (which was not certified by peer review) is the author/funder, who has granted medRxiv a license to display the preprint in perpetuity.

It is made available under a CC-BY-NC-ND 4.0 International license .

\section{PRECURSORS OF BILINGUAL LITERACY DEVELOPMENT}

(i.e., type, measure and language(s) of assessment, and whether assessed in one or both languages), and statistical analyses (i.e., tests, reported significant or non-significant associations between precursors and outcomes assessed in one or both languages). We tabulated frequency of studies relevant to extracted data categories.

For meta-analyses, we extracted sample size, and correlation coefficients, across studies. Although meta-analyses typically compare study effect sizes, only 4/33 studies reported standardized mean-difference effect sizes (Table 4, Appendix A). Following Cochrane Collaboration (2011)'s recommendations to account for violations of statistical independence, we selected a single reported correlation coefficient, based on common pre-identified criteria, for studies reporting multiple correlation coefficients across literacy precursor type.

\section{Database Search}

\section{Results}

The database search resulted in 3096 studies. After duplicate screening of 1732 studies, 1364 abstracts were identified for title/abstract-level screening. After full-text screening and critical appraisal of 323 abstracts, two reviewers independently identified 22 papers meeting inclusion criteria. We manually searched reference lists of these 22 papers and previously excluded non-primary studies (retrieving 22 papers at full-text screening), which resulted in 11 additional papers meeting inclusion/exclusion and critical appraisal criteria (see Figure 1, Appendix A). This review includes 43 studies across 33 papers, comprising scholarly and gray literature (Table 4, Appendix A). 
medRxiv preprint doi: https://doi.org/10.1101/2021.08.18.21262243; this version posted August 23, 2021. The copyright holder for this preprint (which was not certified by peer review) is the author/funder, who has granted medRxiv a license to display the preprint in perpetuity.

It is made available under a CC-BY-NC-ND 4.0 International license .

\section{PRECURSORS OF BILINGUAL LITERACY DEVELOPMENT}

\section{Results Overview}

The study numbers indicated in this section, Tables 1-13 (see Appendix A) and Figures 1-12 (see Appendix A) refer to the 33 papers listed in Table $4 .{ }^{8}$ Below, we provide a synthesis of our findings in table format, in addition to meta-analyses. In total, 17/33 studies reported Pearson's correlations, while 16/33 studies reported other estimation models. We conducted random-effects correlational meta-analyses for precursors, analyzed in at least five independent studies (Jackson \& Turner, 2017), to account for between-study variation in sample size and assessment measures. Similar to prior studies (e.g., Akoglu, 2018), we categorized the strength of Pearson's correlation coefficients $<0.4$ as weak, between $0.4-0.6$ as moderate, and between 0.7-0.9 as strong — and specified statistical significance as $\mathrm{p} \leq 0.05$. The reported precursoroutcome associations do not imply a 1:1 predictive relationship. We acknowledge that primary study statistical limitations — including influences (and range) of sample sizes, confounding variables, and multiple correlational testing — extend to this review. These limitations affirm need for detailed statistical reporting and/or different approaches to examining literacy precursors in future studies.

\section{Participants}

As shown in Table 6 (Appendix A), the most assessed groups were Spanish-English $(n=5)$, Heterogeneous-English $(n=4)$ and Mandarin-English simultaneous bilinguals $(n=7)$. The average age at assessment was 7;5 years, with 13/33 studies assessing children between 8;0-9;12 years $(2,3,5,7,12,14,16,19,20,25,27,28,32)$. In total, 8/33 studies assessed children aged $6 ; 0-7 ; 12$ years $(1,9,18,21,22,23,24,30)$, followed by $4 ; 0-5 ; 12(4,8,11,13,31), 10 ; 0-11 ; 0$ $(15,17,26,29,33)$, and 3;0-3;12 $(6,10)$ years. See Table 5 (Appendix A).

\footnotetext{
${ }^{8}$ We assigned study numbers to reduce text in the Results section.
} 
medRxiv preprint doi: https://doi.org/10.1101/2021.08.18.21262243; this version posted August 23, 2021. The copyright holder for this preprint (which was not certified by peer review) is the author/funder, who has granted medRxiv a license to display the preprint in perpetuity.

It is made available under a CC-BY-NC-ND 4.0 International license .

\section{PRECURSORS OF BILINGUAL LITERACY DEVELOPMENT}

As Tables 6 and 8A-B (Appendix A) indicate, literacy precursors and outcome measures were predominantly assessed in English $(n=22)$, then Spanish $(n=7)$, Chinese $(n=4)$, Welsh $(n=3)$, Hebrew $(n=2)$, French $(n=2)$, Hindi $(n=2)$, Dutch $(n=2)$, Turkish $(n=1)$, Malay $(n=1)$, Italian ( $\mathrm{n}=1)$, Kiswahili $(\mathrm{n}=1)$, Maya $(\mathrm{n}=1)$, German $(\mathrm{n}=1)$, Norwegian $(\mathrm{n}=1)$, and Urdu $(\mathrm{n}=1)$.

\section{Literacy Precursors}

\section{Code-Related, Oral Language, and Domain-General Cognitive Precursors Assessed in}

\section{Relation to Word/Non-Word and Text Reading}

As indicated in Table 7 (Appendix A), this review identified 17 literacy precursors assessed in relation to literacy outcome measures in simultaneous bilingual children. Nine of these precursors have been highlighted as important emergent literacy skills in monolingual English-speaking children (García \& Cain, 2014; Hjetland et al., 2017; NELP, 2008; see goal i):

Code related skills (phonological awareness $[\mathrm{n}=15: 1,2,3,4,7,8,9,14,15,19,22,23$, 24, 32, 33]; letter knowledge [n=2: 4, 13]; serial recall [n=4: 4, 22, 26, 33]); Oral language and grammar skills (oral language comprehension $[\mathrm{n}=3: 10,11,16]$; vocabulary [receptive: $\mathrm{n}=14,1$, $3,8,10,11,16,19,21,22,23,25,26,30,33$; expressive: $n=3,6,24,33$; grammar [syntactic awareness: $n=3,4,17,33$; morphological awareness: $n=5,1,3,5,23,33])$; Domain-general cognitive skills (working memory/verbal short-term memory [n=4: 4, 17, 31, 33]; non-verbal intelligence $[\mathrm{n}=4: 22,31,32,33])$; and word/non-word decoding $(\mathrm{n}=6: 21,23,24,26,30,33)$.

\section{Additional Identified Precursors Assessed in Relation to Word/Non-Word and Text Reading}

As Table 7 (Appendix A) demonstrates, additional literacy precursors identified and assessed in relation to reading include (see goal ii): semantic awareness ( $n=3: 7,9,26)$, spelling $(n=2: 4,17)$, visual attention (VA) span (15), orthographic processing skills (2), environmental 
medRxiv preprint doi: https://doi.org/10.1101/2021.08.18.21262243; this version posted August 23, 2021. The copyright holder for this preprint (which was not certified by peer review) is the author/funder, who has granted medRxiv a license to display the preprint in perpetuity.

It is made available under a CC-BY-NC-ND 4.0 International license .

\section{PRECURSORS OF BILINGUAL LITERACY DEVELOPMENT}

print awareness (4), name writing (13), sub-lexical/phonological speech perception (28), and sentence priming (29). Four studies assessed non-cognitive-linguistic precursors, including type of literacy measure and instruction (12, 18, 20, 27; see Table 6, Appendix A).

\section{Associations between Literacy Precursors and Outcome Measures}

Here, we examine precursor-outcome associations between assessed code-related, oral language, domain-general cognitive, and additional literacy precursors in relation to reading reported in one (goal iii a) or both (goal iii b) spoken languages. Precursor-outcome associations are reported statistically significant or non-significant relationship between a given precursor and outcome measure. We also conducted meta-analyses for specific code-related and oral-language precursors in relation to word/non-word reading and text reading comprehension (see Correlational Meta-Analyses for Code-Related, Oral Language, and Decoding Precursors).

\section{Associations for Code-Related, Oral Language, Domain-General Cognitive, and Additional Identified Precursors in Relation to Word/Non-Word and Text Reading}

\section{Precursors and Outcome Measures Assessed in One Language.}

As Table 8A (Appendix A) demonstrates, 17/33 studies assessed precursors and outcomes in one language (English: $\mathrm{n}=9[1,2,4,7,8,16,23,31,32]$; Other language: $\mathrm{n}=8$ [9, $19,21,24,26,28,29,30])$. Out of these 17 studies, 15 studies demonstrated significant withinlanguage precursor-outcome associations ${ }^{9}(1,2,4,7,8,9,16,19,21,23,24,26,28,30,32)$, one study demonstrated significant across-language precursor-outcome associations ${ }^{10}$ (29), and six

\footnotetext{
${ }^{9}$ In Tables $8 \mathrm{~A}$ and 8B, within-language precursor-outcome associations refer to associations between precursors and outcomes assessed in the same language.

${ }^{10}$ Across-language precursor-outcome associations refer to associations between measures assessed in different languages.
} 
medRxiv preprint doi: https://doi.org/10.1101/2021.08.18.21262243; this version posted August 23, 2021. The copyright holder for this preprint (which was not certified by peer review) is the author/funder, who has granted medRxiv a license to display the preprint in perpetuity.

It is made available under a CC-BY-NC-ND 4.0 International license .

\section{PRECURSORS OF BILINGUAL LITERACY DEVELOPMENT}

studies demonstrated non-significant associations $(1,4,7,9,26,31)$. For the $6 / 33$ studies assessing precursors in both languages and outcomes in one language $(1,6,8,21,30,32)$, four studies demonstrated significant within- and across-language precursor-outcome associations (1, $8,21,32)$, and two studies demonstrated significant within-(30) and across- (6) language associations. Two studies, assessing precursors in one language and outcomes in both languages, demonstrated significant within- and across-language precursor-outcome associations $(5,22)$.

Literacy precursors with consistent significant within-language precursor-outcome associations, in relation to at least one assessed outcome measure across studies, were coderelated (phonological awareness [ $\mathrm{n}=10: 1,2,4,7,8,9,19,23,24,32]$, letter knowledge [4]), oral language (oral language comprehension [16], receptive vocabulary $[\mathrm{n}=9: 1,8,16,19,21$, $22,23,26,30]$, expressive vocabulary [ $\mathrm{n}=2: 6,24]$, syntactic awareness [4]), and additional identified skills (spelling [4], orthographic processing skills [2], environmental print awareness [4], sub-lexical/phonological speech perception [28], and sentence priming [29]). Semantic awareness was not a significant precursor $(7,9,26)$, across both assessed languages.

\section{Interim Discussion}

Similar to English monolinguals, code-related, oral-language, domain-general cognitive, and word/non-word decoding precursors were assessed in simultaneous bilinguals across the 33 included studies (goal i). In addition, we identified eight literacy precursors assessed in simultaneous bilingual children (goal ii). These are: semantic awareness (Ibrahim et al., 2007; Jasińska et al., 2018; Spatgens \& Schoonen, 2018), spelling (Chiappe et al., 2002; D'angiulli et al., 2001), visual attention span (Lallier et al., 2014), orthographic processing (Yeong et al., 2014), environmental print awareness (Chiappe et al., 2002), name writing (Bengochea et al., 2017), sub-lexical/phonological speech perception (Ríos-López et al., 2017), and sentence 
medRxiv preprint doi: https://doi.org/10.1101/2021.08.18.21262243; this version posted August 23, 2021. The copyright holder for this preprint (which was not certified by peer review) is the author/funder, who has granted medRxiv a license to display the preprint in perpetuity.

It is made available under a CC-BY-NC-ND 4.0 International license .

\section{PRECURSORS OF BILINGUAL LITERACY DEVELOPMENT}

priming (Vital \& Karniol, 2011). Significant precursor-outcome associations were evident for code-related, oral-language, and domain-general cognitive skills across heritage and societal languages (Tables 7, 8A and 8B Appendix A for studies; see goal iii); and for the eight additional identified precursors, except for semantic awareness (Jasińska et al., 2018; Ibrahim et al., 2007; Spatgens \& Schoonen, 2018; see goal iii).

Code-related and oral-language skills (specifically, phonological awareness and vocabulary) were commonly assessed precursors consistently associated with reading in children speaking diverse language combinations, including Chinese-English, Hindi-English and SpanishEnglish (e.g., Gupta \& Jamal, 2007; Mak, 2014; Tamis-LeMonda et al., 2014; Zhang, 2016; Tables 8A-B, Appendix A). Particularly, phonological awareness and vocabulary may also be used as precursor screening tools, for early identification of potential reading difficulties in both spoken languages, of simultaneous bilinguals.

Simultaneous bilinguals demonstrated higher phonological awareness and semantic awareness scores, compared to aged-matched monolinguals (Jasińska et al., 2018). Phonological awareness and semantic awareness are metalinguistic skills and they also may reflect a metalinguistic advantage in simultaneous bilinguals (e.g., Adesope et al., 2010; Kroll et al., 2014). However, while both monolinguals and simultaneous bilinguals consistently demonstrated significant precursor-outcome associations for phonological awareness (Chiappe et al., 2002; Hsu et al., 2019; Ibrahim et al., 2007; Jasińska et al., 2018; Limbird et al., 2014; Spencer \& Hanley, 2003; Yeong et al., 2014), only monolinguals and sequential bilinguals demonstrated significant associations between semantic awareness and reading (Ibrahim et al., 2007; Jasińska et al., 2018). 
medRxiv preprint doi: https://doi.org/10.1101/2021.08.18.21262243; this version posted August 23, 2021. The copyright holder for this preprint (which was not certified by peer review) is the author/funder, who has granted medRxiv a license to display the preprint in perpetuity.

It is made available under a CC-BY-NC-ND 4.0 International license .

\section{PRECURSORS OF BILINGUAL LITERACY DEVELOPMENT}

The additional identified precursors are also associated with reading in monolingual children (also see, Bosse \& Valdois, 2009; Both-de Vries \& Bus, 2010; Nation \& Snowling, 1998; Vanvooren et al., 2017). However, further research evaluating their reliability in linguistically-diverse monolingual and bilingual populations is needed. For instance, orthographic processing skills could be relevant to bilinguals learning to read in languages with disparate orthographic characteristics. For Chinese-English bilinguals, cross-language transfer of lexical strategies from the syllabic script, requiring processing of whole character units, may facilitate balanced use of dual — compared to predominant sub-lexical — reading strategies in the alphabetic script (Yeong et al., 2014; Ripamonti et al., 2014).

\section{Correlational Meta-Analyses for Code-Related, Oral Language, and Decoding Precursors}

We conducted random-effects correlational meta-analyses for precursors reporting a minimum of five independent correlation coefficients (Jackson \& Turner, 2017). To account for unit-of-analysis issues, we selected one reported coefficient for studies testing the same group across multiple timepoints, languages and measures. We selected coefficients based on common study features, including testing type (i.e., within-language testing for studies reporting both within- and across-language correlations), testing time (i.e., latest assessment timepoint), assessment language (i.e., English or alphabetic, opaque languages; where possible, we conducted separate analyses per assessment language type [English-only or other language]), precursor measure (i.e., phonemic [versus onset-rime and syllable] awareness, receptive [versus expressive] vocabulary, derivational [versus compound] awareness, and word [versus non-word] decoding), and outcome measure (i.e., word [compared to non-word] reading). 
medRxiv preprint doi: https://doi.org/10.1101/2021.08.18.21262243; this version posted August 23, 2021. The copyright holder for this preprint (which was not certified by peer review) is the author/funder, who has granted medRxiv a license to display the preprint in perpetuity.

It is made available under a CC-BY-NC-ND 4.0 International license .

\section{PRECURSORS OF BILINGUAL LITERACY DEVELOPMENT}

\section{Code-Related and Oral Language Precursors in Relation to Word/Non-Word Reading.}

As Table 9 below and Figures 2-6 (Appendix A) demonstrate, we examined specific code-related (phonological awareness) and oral language/grammar skills (receptive/expressive vocabulary, morphological awareness) in relation to word/non-word reading. We conducted separate meta-analyses, across assessment language (i.e., whether assessed in English or another language), for precursors with at least five independent studies per language type. The analyses were significant for phonological awareness (Figures 2-3), vocabulary (Figures 4-5), and morphological awareness (Figure 6), across language type (see Table 9 for r-coefficient values).

\section{Table 9}

Correlational Meta-Analyses Results Across Precursor Type, in relation to Word and Non-Word Reading. We listed correlational effect size, along with number of studies (n), 95\% CI, p-values and heterogeneity values, for phonological awareness, vocabulary and morphological awareness, in relation to word/non-word reading. When possible, we conducted two separate analyses, based on assessment language (i.e., whether assessed in English only, or another language only).

\begin{tabular}{|c|c|c|c|c|c|c|c|c|}
\hline \multirow{2}{*}{$\begin{array}{l}\text { Literacy } \\
\text { Precursor }\end{array}$} & \multirow{2}{*}{$\begin{array}{c}\text { n } \\
\text { (studi } \\
\text { es) }\end{array}$} & \multirow{2}{*}{$\begin{array}{c}\text { Effect Size } \\
\text { (Correlati } \\
\text { on) }\end{array}$} & \multicolumn{2}{|c|}{$95 \%$ CI } & \multirow[t]{2}{*}{$\mathbf{p}$} & \multicolumn{2}{|c|}{ Heterogeneity } & \multirow[t]{2}{*}{ Figure } \\
\hline & & & Lower & Upper & & $\mathrm{I} 2$ & $\mathrm{p}$ & \\
\hline \multicolumn{9}{|l|}{$\begin{array}{c}\text { Phonological } \\
\text { Awareness }\end{array}$} \\
\hline English & 15 & 0.5068 & 0.4055 & 0.5958 & $*<0.0001$ & $64.1 \%$ & 0.0004 & 2 \\
\hline $\begin{array}{c}\text { Other Language } \\
\text { (Non-English) }\end{array}$ & 5 & 0.3563 & 0.1169 & 0.5565 & $* 0.0042$ & $58.8 \%$ & 0.0455 & 3 \\
\hline \multicolumn{9}{|l|}{ Vocabulary: } \\
\hline English & 12 & 0.4027 & 0.2862 & 0.5075 & $*<0.0001$ & $60.9 \%$ & 0.0031 & 4 \\
\hline $\begin{array}{c}\text { Other Language } \\
\text { (Non-English) }\end{array}$ & 5 & 0.3133 & 0.1383 & 0.4692 & $* 0.0006$ & $53.5 \%$ & 0.0719 & 5 \\
\hline
\end{tabular}


medRxiv preprint doi: https://doi.org/10.1101/2021.08.18.21262243; this version posted August 23, 2021. The copyright holder for this preprint (which was not certified by peer review) is the author/funder, who has granted medRxiv a license to display the preprint in perpetuity.

It is made available under a CC-BY-NC-ND 4.0 International license .

\section{PRECURSORS OF BILINGUAL LITERACY DEVELOPMENT}
Morphological
$6 \quad 0.5005$
0.1441
0.7420
$* 0.0078$
$85.8 \%<0.0001$
6

Awareness

Note $^{*}=$ significant $\mathrm{p}$-value $<0.05$. See Figures $2-6$ for corresponding random-effect models.

\section{Oral Language Precursors and Word/Non-Word Decoding Skills in Relation to Text Reading}

\section{Comprehension.}

As Table 10 below and Figures 7-8 (Appendix A) demonstrate, our analyses were significant for specific oral language (vocabulary; Figure 7), and word/non-word decoding skills (Figure 8) in relation to text reading comprehension (see Table 10 for r-coefficient values).

\section{Table 10}

Correlational Meta-Analyses Results Across Precursor Type, in relation to Text Reading Comprehension. We listed correlational effect size, along with number of studies (n), 95\% CI, pvalues and heterogeneity values, for vocabulary and word/non-word decoding, in relation to text comprehension.

\begin{tabular}{ccccccccc}
\hline $\begin{array}{c}\text { Literacy } \\
\text { Precursor }\end{array}$ & $\begin{array}{c}\mathbf{n} \\
\text { (studies) }\end{array}$ & $\begin{array}{c}\text { Effect Size } \\
\text { (Correlatio } \\
\text { n) }\end{array}$ & \multicolumn{2}{c}{$\mathbf{9 5 \%}$ CI } & $\mathbf{p}$ & \multicolumn{2}{c}{ Heterogeneity } & Figure \\
\hline Vocabulary & 8 & 0.5706 & 0.3669 & 0.7221 & $*<0.0001$ & $77.9 \%$ & $<0.0001$ & 7 \\
& & & & & & & & \\
$\begin{array}{c}\text { Word and } \\
\begin{array}{c}\text { Non-Word } \\
\text { Decoding }\end{array}\end{array}$ & 5 & 0.6741 & 0.3705 & 0.8476 & $* 0.0002$ & $90.3 \%$ & $<0.0001$ & 8 \\
\hline
\end{tabular}

Note $^{*}=$ significant $\mathrm{p}$-value $<0.05$. See Figures 7-8 for corresponding random-effect models.

Code-Related and Oral Language Precursors, in relation to Word/Non-Word Reading, based on Type of Testing, Writing System and Country of Assessment.

As evident in Table 11 and Figures 9-11 (Appendix A), we conducted meta-analyses for code-related skills (specifically, phonological awareness) in relation to word/non-word reading - 
medRxiv preprint doi: https://doi.org/10.1101/2021.08.18.21262243; this version posted August 23, 2021. The copyright holder for this preprint (which was not certified by peer review) is the author/funder, who has granted medRxiv a license to display the preprint in perpetuity.

It is made available under a CC-BY-NC-ND 4.0 International license .

\section{PRECURSORS OF BILINGUAL LITERACY DEVELOPMENT}

— based on type of testing (i.e., whether assessed in same [within] or different [across] language), writing system (i.e., whether bilinguals, assessed in an alphabetic language ${ }^{11}$, spoke syllabic-alphabetic or alphabetic-alphabetic combinations), and assessment country (i.e., whether Chinese-English bilinguals were assessed, on English measures, in Canada/US or Singapore).

The analysis for phonological awareness and word/non-word reading was significant only in relation to type of writing system (test for subgroup differences $[Q]=3.97 ; p=0.0463$, Figure 10 [syllabic-alphabetic bilinguals: $\mathrm{r}=0.5708 ; 95 \% \mathrm{CI}: 0.4813,0.6485 ;$ studies $=11 ; \mathrm{n}=654$ ]; [alphabetic-alphabetic bilinguals: $r=0.3763 ; 95 \% \mathrm{CI}: 0.1781,0.5451$; studies $=5 ; \mathrm{n}=412$ ]). The analyses were not significant in relation to testing condition $(\mathrm{Q}=2.48 ; \mathrm{p}=0.1154$, Figure 9 [within-language: $\mathrm{r}=0.5031 ; 95 \% \mathrm{CI}: 0.4098,0.5860$; studies $=17 ; \mathrm{n}=1125$ ]; [across-language: $\mathrm{r}=0.3485 ; 95 \% \mathrm{CI}: 0.1577,0.5142 ;$ studies $=5 ; \mathrm{n}=231])$, and country of assessment $(\mathrm{Q}=0.09$; $\mathrm{p}=0.7610$, Figure 11 [Canada/US: $r=0.5813 ; 95 \%$ CI: 0.4453, 0.6910; studies $=6 ; n=237$; [Singapore: $\mathrm{r}=0.5553 ; 95 \% \mathrm{CI}: 0.4322,0.6581$; studies $=5 ; \mathrm{n}=654]$ ).

As evident in Table 12 and Figure 12 (Appendix A), the meta-analysis for oral language skills (vocabulary) and word/non-word reading was significant for testing condition $(\mathrm{Q}=5.32$; $\mathrm{p}=0.0210$, Figure 12 [within-language: $\mathrm{r}=0.4221 ; 95 \% \mathrm{CI}: 0.28889,0.5392 ;$ studies $=11 ; \mathrm{n}=$ 459]; [across-language: $r=0.2026 ; 95 \% \mathrm{CI}: 0.0644,0.3332$; studies $=7 ; \mathrm{n}=870]$ ).

\section{Interim Discussion}

Similar to English monolinguals, commonly-assessed code-related (phonological awareness: Chiappe et al., 2002; Hsu et al., 2019; Ibrahim et al., 2007; Jasińska et al., 2018; Limbird et al., 2014; Spencer \& Hanley, 2003; Yeong et al., 2014) and oral-language

\footnotetext{
${ }^{11}$ Most alphabetic within-language assessments were conducted in English, except for Hebrew and French (studies 9 and 15).
} 
medRxiv preprint doi: https://doi.org/10.1101/2021.08.18.21262243; this version posted August 23, 2021. The copyright holder for this preprint (which was not certified by peer review) is the author/funder, who has granted medRxiv a license to display the preprint in perpetuity.

It is made available under a CC-BY-NC-ND 4.0 International license .

\section{PRECURSORS OF BILINGUAL LITERACY DEVELOPMENT}

(vocabulary: Hsu et al., 2019; Lervåg \& Aukrust, 2009; Limbird et al., 2014; Rhys \& Thomas, 2013; Spatgens \& Schoonen, 2018; van den Bosch et al., 2020; also see, Hjetland et al., 2017;

NELP, 2008) precursors were associated with word/non-word reading across English and heritage languages of bilinguals. Associations were also evident between morphological awareness and word/non-word reading, as well as for vocabulary and word/non-word decoding in relation to text reading comprehension (see Tables 9-10, and goal iii).

The evident differences in correlational strength for phonological awareness and vocabulary in relation to word/non-word reading, across the two languages, may be due to greater degree of English usage/exposure or language-specific linguistic differences (i.e., based on phonological and orthographic structure). Yeong et al. (2014) demonstrate influence of language exposure and assessment measure type on precursor skills. Chinese-English simultaneous bilinguals, with greater English home-language exposure, demonstrated significantly higher scores on English receptive vocabulary and specific phonological awareness measures (i.e., for phoneme and syllable blending, but not elision), compared to bilinguals with greater Chinese exposure. However, we could not examine whether language proficiency mediates this relationship, as limited studies reported language usage/exposure rates.

Similarly, correlational strength differences demonstrated for phonological awareness and word/non-word reading, in relation to writing system type (see Table 11, Appendix A), may be due to language-specific linguistic influences or differential degree of proficiency across heritage and societal languages. In monolingual readers, orthography type mediates relationship between specific phonological awareness measures and reading. Phonemic awareness is strongly associated with word reading in alphabetic orthographies. Conversely, syllabic awareness is a 
medRxiv preprint doi: https://doi.org/10.1101/2021.08.18.21262243; this version posted August 23, 2021. The copyright holder for this preprint (which was not certified by peer review) is the author/funder, who has granted medRxiv a license to display the preprint in perpetuity.

It is made available under a CC-BY-NC-ND 4.0 International license .

\section{PRECURSORS OF BILINGUAL LITERACY DEVELOPMENT}

reliable precursor of character recognition in morpho-syllabic languages, primarily utilizing lexical strategies to process larger phonological grain sizes (McBride-Chang et al., 2004).

Cross-language transfer of sub-lexical and lexical reading strategies is evident, even between languages with differing scripts (O’Brien et al., 2019). As compared to Malay-English and Tamil-English bilinguals, speaking alphabetic-alphabetic combinations, Chinese-English bilinguals showed the strongest precursor-outcome associations for English onset-rime awareness, compared to phonemic and syllable awareness, in relation to reading. Along with sub-lexical phonemic processes, the bilinguals utilized lexical, involving onset- and syllablelevel processing from the morpho-syllabic heritage language, strategies for English word reading (O’Brien et al., 2019). As such, we expected stronger correlations between phonemic awareness and word/non-word reading in the alphabetic-alphabetic bilingual group. However, syllabicalphabetic bilinguals demonstrated moderate-level correlations, while alphabetic-alphabetic bilinguals demonstrated weak-level correlations (see Table 11 and Figure 10, Appendix A). These differences may be due to greater degree of language proficiency for the assessed alphabetic language in syllabic-alphabetic bilinguals — rather than orthographic influences.

Bilinguals comprise a heterogenous group, as they vary in language dominance, proficiency, sources of exposure, and linguistic context (De Bruin, 2019). While our review minimized heterogeneity by only focusing on simultaneous bilinguals, some factors (e.g., language proficiency and dominance) remain unexamined. This is because limited studies reported proficiency measures. Only 4/33 studies reported degree of language exposure (Hsu et al., 2019; Sun et al., 2021; Yang, 2010; Yeong et al., 2014) with 3/4 studies reporting language exposure details in both languages, while no studies reported degree of language usage. 
medRxiv preprint doi: https://doi.org/10.1101/2021.08.18.21262243; this version posted August 23, 2021. The copyright holder for this preprint (which was not certified by peer review) is the author/funder, who has granted medRxiv a license to display the preprint in perpetuity.

It is made available under a CC-BY-NC-ND 4.0 International license .

\section{PRECURSORS OF BILINGUAL LITERACY DEVELOPMENT}

Due to limited language background reporting, we considered country of assessment as an indirect indicator of English proficiency in Chinese-English bilinguals — assuming dominance for the societal language. The assessment country (i.e., whether English-dominant, such as Canada or the US, or non-English dominant, such as Singapore; Table 11 and Figure 11) did not mediate the relationship between English phonological awareness and word/non-word reading. However, this may be due to statistical power; only 11/33 independent studies assessed English phonological awareness and word/non-word reading skills across the two countries (Hipfner-Boucher et al., 2014; Yeong et al., 2014; Hsu et al., 2019; O'Brien et al., 2019; Lam et al., 2012; Ríos-López et al., 2017). We could not examine influences of assessment country on Chinese literacy skills, as few studies assessed both languages (Hsu et al., 2019; Mak, 2014).

\section{Precursors and Outcome Measures Assessed in Both Languages}

As evident in Table 8B (Appendix A), 11/33 studies assessed precursors and outcome measures in both languages (English and another language: $n=9[3,7,10,11,14,17,22,25,33]$; Two other languages: $n=2[13,15])$. When both languages were assessed, three studies demonstrated significant within-language associations for one language ${ }^{12}(7,13,33), 10$ studies $^{2}$ demonstrated significant within-language associations for both languages ${ }^{13}(3,10,11,13,14,15$, $17,22,25,33)$, two studies demonstrated significant across-language associations for outcomes in one language ${ }^{14}(17,33)$, six studies demonstrated significant across-language associations for

\footnotetext{
${ }^{12}$ In Table 8B, significant within-language precursor-outcome associations for one language refers to precursors and outcomes assessed in the same language (and significant in one language).

13 Significant within-language precursor-outcome associations for both languages refers to measures assessed in the same language (and significant in both languages).

14 The term significant across-language precursor-outcome associations for literacy outcomes in one language refers to measures assessed in different languages (and significant for outcomes in one language).
} 
medRxiv preprint doi: https://doi.org/10.1101/2021.08.18.21262243; this version posted August 23, 2021. The copyright holder for this preprint (which was not certified by peer review) is the author/funder, who has granted medRxiv a license to display the preprint in perpetuity.

It is made available under a CC-BY-NC-ND 4.0 International license .

\section{PRECURSORS OF BILINGUAL LITERACY DEVELOPMENT}

outcomes in both languages ${ }^{15}(10,11,13,15,17,22)$, two studies demonstrated non-significant across-language associations $(3,33)$, and one study demonstrated non-significant within- and across-language associations in both languages (7).

Literacy precursors with significant consistent within- and/or across-language precursoroutcome associations, in relation to at least one assessed outcome measure, were the following code-related (phonological awareness [ $\mathrm{n}=6: 3,7,14,15,22,33$ ], letter knowledge [13], serial recall [33]), oral language (oral language comprehension $[\mathrm{n}=2: 10,11]$, receptive/expressive vocabulary $[\mathrm{n}=5: 3,10,11,25,33]$, syntactic awareness $[\mathrm{n}=2: 17,33]$, morphological awareness $[\mathrm{n}=2: 3,33]$ ), domain-general cognitive (working memory $[\mathrm{n}=2: 17,33]$, non-verbal intelligence [33]), word/non-word decoding (33), and additional identified skills (spelling [17], VA span [15], and name writing [13]). Tables 7, 8A and 8B (Appendix A) indicate significant precursoroutcome associations for papers reporting at least one significant association for the same group, across multiple within- and/or across-language assessment measures or timepoints.

\section{Associations based on Word/Non-Word or Text Reading Measures}

In line with goal (iv), Table 7 (Appendix A) illustrates that precursors were assessed in relation to the following reading measures: word reading accuracy $(\mathrm{n}=24: 1,2,3,4,5,6,7,8,9$, $10,11,13,14,15,16,17,22,23,25,28,30,31,32,33)$ and speed $(\mathrm{n}=3: 5,15,28)$, non-word reading accuracy $(\mathrm{n}=7: 9,14,15,16,17,28,33)$ and speed $(\mathrm{n}=2: 15,28)$, text reading accuracy $(\mathrm{n}=5: 9,15,25,28,29)$ and speed $(\mathrm{n}=5: 9,15,19,28,29)$, and text comprehension $(\mathrm{n}=10: 11,16$, $21,23,24,25,26,29,30,33)$.

${ }^{15}$ Significant across-language precursor-outcome associations for literacy outcomes in both languages refers to measures assessed in different languages (and significant for outcomes in both languages). 
medRxiv preprint doi: https://doi.org/10.1101/2021.08.18.21262243; this version posted August 23, 2021. The copyright holder for this preprint (which was not certified by peer review) is the author/funder, who has granted medRxiv a license to display the preprint in perpetuity.

It is made available under a CC-BY-NC-ND 4.0 International license .

\section{PRECURSORS OF BILINGUAL LITERACY DEVELOPMENT}

A total of 13/33 studies assessed precursors in comparison to multiple outcome measures $(5,9,11,14,15,16,17,23,25,28,29,30,33)$. In 6/13 studies, bilinguals demonstrated significant precursor-outcome associations for code-related (phonological awareness:15), oral language (receptive vocabulary [30]; syntactic [17, 33] and morphological awareness [5]), domain-general cognitive (working memory [17, 33], non-verbal intelligence [33], and additional identified (VA span [15], sub-lexical speech perception [28]) literacy precursors, only in relation to specific outcome measures and assessment languages (see Table 7, Appendix A):

\section{Code-Related Precursors}

Phonological Awareness. Spanish-French bilinguals demonstrated significant associations between Spanish phonological awareness and word reading accuracy, and for Spanish and French non-word and text reading accuracy. However, non-significant associations were evident in relation to word, non-word and text reading speed across languages (study 15, Table 7 in Appendix A).

\section{Oral-Language Precursors}

Vocabulary. Turkish-Dutch bilinguals demonstrated significant associations between receptive vocabulary and text reading comprehension, but not word reading accuracy (30).

Syntactic Awareness. Italian-English bilinguals demonstrated significant associations between Italian and English syntactic awareness and word reading accuracy, and for Italian nonword reading accuracy (17). Chinese-English bilinguals demonstrated significant associations between syntactic awareness and text reading comprehension, but not word and non-word reading accuracy (33). 
medRxiv preprint doi: https://doi.org/10.1101/2021.08.18.21262243; this version posted August 23, 2021. The copyright holder for this preprint (which was not certified by peer review) is the author/funder, who has granted medRxiv a license to display the preprint in perpetuity.

It is made available under a CC-BY-NC-ND 4.0 International license .

\section{PRECURSORS OF BILINGUAL LITERACY DEVELOPMENT}

Morphological Awareness. Malay-English bilinguals demonstrated significant associations between morphological awareness and word reading accuracy, but not word reading speed (5).

\section{Domain-General Cognitive Precursors}

Working Memory. Italian-English bilinguals demonstrated significant associations between Italian working memory and word reading accuracy, but not non-word reading accuracy, across languages (17). Chinese-English bilinguals demonstrated significant associations between working memory and text reading comprehension, but not word and nonword reading accuracy (33).

Non-Verbal Intelligence. Chinese-English bilinguals demonstrated significant associations between non-verbal intelligence and text reading comprehension, but not word and non-word reading accuracy (33).

\section{Additional Identified Precursors}

Semantic Awareness. Simultaneous bilinguals demonstrated non-significant associations for semantic awareness across word, non-word and text reading accuracy $(7,9)$, text reading speed (9) and comprehension (26) outcome measures.

Visual Attention (VA) Span. Spanish-French bilinguals demonstrated significant associations for VA span in relation to Spanish and French word and non-word reading accuracy and speed, and text reading speed, and for French text reading accuracy (15).

Sub-Lexical/Phonological Speech Perception. Basque-Spanish bilinguals demonstrated significant associations for speech perception in relation to word, non-word and text reading speed, but not accuracy (28). 
medRxiv preprint doi: https://doi.org/10.1101/2021.08.18.21262243; this version posted August 23, 2021. The copyright holder for this preprint (which was not certified by peer review) is the author/funder, who has granted medRxiv a license to display the preprint in perpetuity.

It is made available under a CC-BY-NC-ND 4.0 International license .

\section{PRECURSORS OF BILINGUAL LITERACY DEVELOPMENT}

\section{Interim Discussion}

We also found that type of outcome measure, whether word, non-word or text-level reading, can also affect literacy precursor assessment (see goal iv). Reading measures may be differentially sensitive for certain precursors, depending on AoA, proficiency, reading experience, and languages of assessment (Lervåg \& Aukrust, 2009; Limbird et al., 2014; Rhys \& Thomas, 2013). To the best of our knowledge, this has not been investigated in monolingual English-speaking children. Previous studies have not compared associations for specific literacy precursors in relation to multiple reading measures, assessed at the same time-point. In English monolinguals, reading experience has been highlighted as a factor influencing associations for code-related and oral language skills, in relation to specific outcome measures. Kindergarten code-related skills, including phonemic awareness, are a comparatively stronger predictor of early Grade 1 and 2 word/non-word-level decoding and recognition. Conversely, prior reading and oral language skills, including vocabulary and grammar, strongly contribute to Grade 3-4 reading comprehension (e.g., Hulme et al., 2015; Storch \& Whitehurst, 2002).

In Spanish-English and French-English simultaneous bilinguals with shared romance language families, receptive vocabulary more strongly correlated with text comprehension compared to word reading for sequential bilinguals (Bérubé \& Marinova-Todd, 2012; Dunn et al., 2011). Further, Turkish-Dutch bilinguals demonstrated significant associations between vocabulary and text comprehension, but not for word reading (van den Bosch et al., 2020). The language of assessment also mediated associations for code-related precursors evaluated in relation to multiple reading measures. Spanish-French bilinguals demonstrated significant associations for phonological awareness in relation to non-word and text-reading accuracy across languages; however, reading speed was not a sensitive outcome measure. Further, they showed 
medRxiv preprint doi: https://doi.org/10.1101/2021.08.18.21262243; this version posted August 23, 2021. The copyright holder for this preprint (which was not certified by peer review) is the author/funder, who has granted medRxiv a license to display the preprint in perpetuity.

It is made available under a CC-BY-NC-ND 4.0 International license .

\section{PRECURSORS OF BILINGUAL LITERACY DEVELOPMENT}

significant associations in relation to Spanish word reading, but not when assessed in French (Lallier et al., 2014). To address concerns regarding word/non-word reading - compared to text comprehension - difficulties, further research is needed to investigate which skills are reliable precursors of specific reading measures in bilingual children, depending on language(s) spoken.

\section{Language Background Measures Assessed in Relation to Precursors and Word/Non-Word and Text Reading Measures}

To address goal (v), this section reports language background influences on code-related, oral-language, domain general cognitive and additional identified precursors and reading skills across the 33 included papers. As evident in Table 13 (Appendix A), 26/33 studies assessed language proficiency $(1,2,3,7,8,10,11,13,14,15,16,17,18,20,21,23,24,25,26,27,28$, 29, 30, 31, 32, 33). Most studies assessed parent-completed questionnaires/interviews ( $\mathrm{n}=24: 1$, $2,3,7,8,10,11,13,14,15,16,18,20,21,23,24,25,27,28,29,30,31,32,33)$, then oral language comprehension/production tasks $(\mathrm{n}=6: 7,10,11,14,20,24)$, teacher-completed questionnaires/interviews or classroom observations $(\mathrm{n}=5: 8,14,15,24,27)$, child-completed interviews ( $\mathrm{n}=3: 20,24,26)$, and word/non-word reading tasks $(\mathrm{n}=2: 14,17)$. Five studies analyzed language proficiency influences on precursor and outcome measure performance (12, $17,28,31,32$ ), with two studies (17 and 32) demonstrating significant moderating effects of proficiency on literacy precursor (i.e., Italian and English syntactic awareness and spelling, but not working memory [17]) and outcome (i.e., Italian and English word/non-word reading [17] and Chinese character recognition [32]) performance.

Out of 16/33 studies assessing receptive/expressive vocabulary as precursors in relation to outcome measures $(1,3,6,8,10,11,16,19,21,22,23,24,25,26,30,33), 6 / 16$ studies demonstrated significant associations between vocabulary and additional precursors $(1,3,8,16$, 
medRxiv preprint doi: https://doi.org/10.1101/2021.08.18.21262243; this version posted August 23, 2021. The copyright holder for this preprint (which was not certified by peer review) is the author/funder, who has granted medRxiv a license to display the preprint in perpetuity.

It is made available under a CC-BY-NC-ND 4.0 International license .

\section{PRECURSORS OF BILINGUAL LITERACY DEVELOPMENT}

$23,33)$, and between outcome measures. However, 10/16 studies analyzed vocabulary in relation to literacy outcomes, but not additional precursors $(6,10,11,19,21,22,24,25,26,30)$.

\section{General Discussion}

While code-related, oral-language and domain-general cognitive literacy precursors are relatively well studied in monolinguals (e.g., Hjetland et al., 2020; Kirby et al., 2008, 2010; Melby-Lervåg et al., 2012), factors shaping biliteracy development are still not well understood. Bilingual performance on oral language and literacy measures is typically affected by AoA and proficiency across spoken languages (Kovelman et al., 2008, 2015; Thordardottir, 2019). Here, we kept AoA constant by focusing on simultaneous bilinguals - and examined other language background influences, including proficiency level, cross-language transfer effects and language(s) of assessment, on emergent literacy skills.

It is unclear which language proficiency measures are reliably associated with literacy performance. While most studies assessed multiple proficiency measures, few reported specific exposure or usage rates across both languages (Yeong et al., 2014; Hsu et al., 2019; Yang, 2010), and analyzed proficiency influences on emergent literacy skills (D’angiulli et al., 2001; Oller et al., 2007; Ríos-López et al., 2017; Sun et al., 2021; Yang, 2010).

Along with parental reports and standardized oral language measures, vocabulary is a good indicator of language proficiency, and contributes to reading ability (Peets et al., 2019). Studies assessed vocabulary as a precursor in relation to reading (see Table 13, Appendix A); however, they did not use vocabulary as a proficiency measure, nor analyze influences on precursor-outcome associations. Convergent validity between vocabulary and language background measures was also not examined in the reviewed studies. Assessing vocabulary, both as distinct and combined skills across spoken languages, would enable analysis of language- 
medRxiv preprint doi: https://doi.org/10.1101/2021.08.18.21262243; this version posted August 23, 2021. The copyright holder for this preprint (which was not certified by peer review) is the author/funder, who has granted medRxiv a license to display the preprint in perpetuity.

It is made available under a CC-BY-NC-ND 4.0 International license .

\section{PRECURSORS OF BILINGUAL LITERACY DEVELOPMENT}

specific proficiency, as compared to language-general ability, contributions to biliteracy development. Further, receptive and expressive vocabulary measures each inform different aspects of bilingual status; however, only one study assessed both vocabulary constructs (Mak, 2014). Expressive vocabulary may be an indicator of language dominance in non-balanced simultaneous bilinguals, while receptive vocabulary allows comparison across language dominance due to earlier onset (Gibson et al., 2014). Receptive measures are particularly informative, when expressive vocabulary cannot be assessed depending on proficiency levels.

While vocabulary measures are a relatively objective language proficiency measure, they do not capture sufficient bilingual profile information — including AoA, linguistic distance ${ }^{16}$ and duration/quality of language exposure, usage and dominance — which also influences coderelated and oral language skills (Haman et al., 2017; Jasińska et al., 2019). Assessing multiple proficiency measures, such as standardized oral language tools and parental reports, will enable analysis of how different aspects of proficiency influence biliteracy development (De Bruin et al., 2017). Access to adequate language background information would enable interpretation of correlational strength differences demonstrated, between syllabic-alphabetic and alphabeticalphabetic bilinguals, for phonological awareness and reading. These differences may be due to language proficiency or linguistic (e.g., orthographic systems or cross-language interference from an alphabetic language with closer linguistic distance) reasons (Table 11 and Figure 10).

Comprehensive language background evaluation will facilitate a better understanding of oral-language, compared to domain-general cognitive, influences on meta-linguistic precursors such as phonological awareness. These skills involve both language (via vocabulary knowledge) and cognition/memory (via identification and manipulation of familiar spoken-sound structures)

${ }^{16}$ The percentage of shared phonologically or semantically-related cognates across languages. 
medRxiv preprint doi: https://doi.org/10.1101/2021.08.18.21262243; this version posted August 23, 2021. The copyright holder for this preprint (which was not certified by peer review) is the author/funder, who has granted medRxiv a license to display the preprint in perpetuity.

It is made available under a CC-BY-NC-ND 4.0 International license .

\section{PRECURSORS OF BILINGUAL LITERACY DEVELOPMENT}

components. Such analysis is important for disentangling language-general, compared to language-specific proficiency, influences of oral-language measures for literacy acquisition. This is because vocabulary skills can be an indicator of proficiency - in addition to their role as precursors of emergent literacy development, including age-appropriate phonological awareness, in monolingual and bilingual children (Chung \& Bidelman, 2021; Kalia et al., 2018).

Along with examining associations for code-related and oral-language precursors in the same language (i.e., within-language testing), some studies also examined cross-language transfer effects for these precursors across different languages (i.e., across-language testing). The cross-language transfer effects for phonological awareness and vocabulary highlight how supporting precursors in the heritage language can facilitate reading development in the educational language (and vice-versa; see Tables 8A-B for across-language precursor-outcome associations, and Tables 11-12, Appendix A for meta-analyses across testing condition ${ }^{17}$ ). Given limited language-specific precursor screening tools, such bi-directional findings are informative for clinicians. It should also be examined whether print-based precursors, such as name writing (Bengochea et al., 2017), visual attention (VA) span (Lallier et al., 2014) and serial recall (Spencer \& Hanley, 2003), can be assessed once to reflect literacy skills of bilingual children speaking language combinations with shared orthographic/numeral systems and closer linguistic distance. Clinicians can facilitate literacy development, in the language of education, by assessing and providing early reading intervention for code-related and oral-language precursors in the dominant heritage or societal language (Kim \& Piper, 2019). While within-language

\footnotetext{
${ }^{17}$ Whether children were assessed for phonological awareness or vocabulary literacy precursors in relation to word/non-word reading outcome measures in the same (within-language) or different (across-language) language. See Tables 11 and 12 (Appendix A), for correlational meta-analyses pertaining to testing condition.
} 
medRxiv preprint doi: https://doi.org/10.1101/2021.08.18.21262243; this version posted August 23, 2021. The copyright holder for this preprint (which was not certified by peer review) is the author/funder, who has granted medRxiv a license to display the preprint in perpetuity.

It is made available under a CC-BY-NC-ND 4.0 International license .

\section{PRECURSORS OF BILINGUAL LITERACY DEVELOPMENT}

testing in both languages enables comprehensive evaluation of biliteracy development milestones, across-language testing may contribute preliminary diagnostic information for early identification of oral language and reading difficulties — if literacy assessments are not available across spoken languages.

Assessing bilinguals across spoken languages will also enable identification of factors, such as linguistic and orthographic ${ }^{18}$ distance, that facilitate bidirectional cross-language transfer of code-related and oral language precursors in Simple View of Reading (SVR) and Dual Route Model of Reading. Spanish-French, Spanish-English and Welsh-English bilinguals, with shared alphabetic orthographies and closer linguistic distance, demonstrated significant within- and bidirectional across-language associations for phonological awareness (Lallier et al., 2014; Spencer \& Hanley, 2003) and oral language (Dunn et al., 2011; Hammer et al., 2007; Rhys \& Thomas, 2013). However, Chinese (morpho-syllabic) - English (alphabetic) bilinguals only demonstrated significant within-language associations (Hsu et al., 2019; Mak, 2014).

This review also demonstrated an English-language assessment bias, with limited studies assessing literacy skills across heritage and societal languages. Most assessments were conducted only in English (Hipfner-Boucher et al., 2014; Yeong et al., 2014; Chiappe et al., 2002; Hsu et al., 2019; O'Brien et al., 2019; Bérubé \& Marinova-Todd, 2012; Lam et al., 2012; Sun et al., 2021; Yang, 2010), or in English and a heritage language (Hsu et al., 2019; Jasińska et al., 2018; Hammer et al., 2007; Dunn et al., 2011; Cherodath \& Singh, 2015; D'angiulli et al., 2001; Spencer \& Hanley, 2003; Rhys \& Thomas, 2013; Mak, 2014). The stronger correlations for within-, compared to across-, language testing for vocabulary and word/non-word reading

\footnotetext{
18 The degree of orthographic variation, including the smallest unit of sound-symbol representation, across languages.
} 
medRxiv preprint doi: https://doi.org/10.1101/2021.08.18.21262243; this version posted August 23, 2021. The copyright holder for this preprint (which was not certified by peer review) is the author/funder, who has granted medRxiv a license to display the preprint in perpetuity.

It is made available under a CC-BY-NC-ND 4.0 International license .

\section{PRECURSORS OF BILINGUAL LITERACY DEVELOPMENT}

emphasize importance of developing language-specific precursor screening tools to evaluate and support emergent literacy skills across spoken languages (Table 12, Appendix A).

Assessing both languages will also enable investigation of factors facilitating — or inhibiting — biliteracy development and cross-language transfer of emergent literacy skills, in speakers of disparate orthographic combinations such as Chinese-English bilinguals (Bérubé \& Marinova-Todd, 2012; Hipfner-Boucher et al., 2014; Lam et al., 2012). Reading models, including Script Dependent Hypothesis (SDH) and Linguistic Interdependence Hypothesis (LIH), have predominantly examined reading development in monolingual readers of alphabetic and non-alphabetic languages, and cross-language transfer effects in alphabetic-alphabetic bilinguals (e.g., Ellis \& Hooper, 2001). In monolinguals, type of orthographic system and degree of orthographic depth influence the relationship between phonological awareness measures and word/non-word reading (McBride-Chang et al., 2004; Defior, 2004). While phonemic awareness is a strong contributor to word recognition across orthographic depth in alphabetic languages, syllable awareness is a more sensitive measure of phonological awareness abilities in morphosyllabic languages (McBride-Chang et al., 2004). Further, orthographic depth influences onset and age-related contributions of phonological awareness to reading in alphabetic orthographies. While readers of transparent languages develop awareness of phonological units earlier (Defior, 2004), phonological awareness is a comparatively stronger long-term contributor to reading, across primary and secondary grades, in opaque orthographies (Furnes \& Samuelsson, 2010; Ziegler et al., 2010). 
medRxiv preprint doi: https://doi.org/10.1101/2021.08.18.21262243; this version posted August 23, 2021. The copyright holder for this preprint (which was not certified by peer review) is the author/funder, who has granted medRxiv a license to display the preprint in perpetuity.

It is made available under a CC-BY-NC-ND 4.0 International license .

\section{PRECURSORS OF BILINGUAL LITERACY DEVELOPMENT}

Limited studies have investigated how interactions between language-specific factors, such as linguistic distance and orthographic depth — whether transparent ${ }^{19}$ or opaque $^{20}$ — in addition to proficiency levels, mediate relationships between specific precursors and outcome measures, across the two languages. Specific to bilinguals, degree of proficiency and linguistic/orthographic distance across spoken languages influence emergent biliteracy development, including cross-language transfer effects. Interactions between phonological and orthographic systems, whether shared or disparate, may influence cross-language transfer of sublexical and lexical reading strategies and underlying code-related and oral-language skills. Due to statistical limitations, our meta-analyses did not investigate language background influences on reported precursor-outcome associations. Such research would allow a better understanding of relevance of current reading models for bilingual populations across language background and dominancy profiles. Linguistically-diverse research would also enable assessment and interpretation of bilingual performance on standardized literacy measures, based on norms derived from populations with similar language status — rather than direct comparison with English monolinguals.

\footnotetext{
${ }^{19}$ Writing systems with a one-to-one phoneme-grapheme correspondence such as Hindi, Spanish and Welsh. In phonologically-consistent/transparent alphabetic orthographies, word reading is more directly predicted by spelling. This is due to the predictable relationship between an individual phoneme and its representation/grapheme, which helps children with acquiring the alphabetic principle and learning to read (i.e., via sub-lexical reading strategies).

${ }^{20}$ Phonologically inconsistent writing systems, such as English or French, where an individual phoneme can be represented by multiple graphemes. In opaque alphabetic orthographies, words cannot always be phonologically decoded due to unpredictable phoneme-grapheme correspondences; children learn to recognize/memorize and read high frequency and irregular words via whole/sight word reading (i.e., lexical) strategies.
} 
medRxiv preprint doi: https://doi.org/10.1101/2021.08.18.21262243; this version posted August 23, 2021. The copyright holder for this preprint (which was not certified by peer review) is the author/funder, who has granted medRxiv a license to display the preprint in perpetuity.

It is made available under a CC-BY-NC-ND 4.0 International license .

\section{PRECURSORS OF BILINGUAL LITERACY DEVELOPMENT}

\section{Study Limitations: Correlational Meta-Analyses}

Most research in this domain examines correlational analyses (e.g., Hjetland et al., 2017;

NELP, 2008). While papers typically combine correlational values for studies reporting multiple values, across literacy measures and assessment timepoints, averaging dependent studies may overestimate sampling error. Common Fisher-z Transformation of r-coefficients and HunterSchmidt (20115) corrections are based on test assumptions not typically reported, such as sample statistical independence and bivariate normality. The Hunter-Schmidt (2015) method also requires access to inter-correlational values for combined measures or timepoints. These values are comparatively difficult to access, as limited biliteracy studies assess specific language combinations and similar literacy measures. To ensure statistical independence, we selected one correlation, based on common assessment and language features, for studies reporting multiple coefficients for the same precursor across reading outcomes, languages and timepoints. Further, correlational studies typically analyze precursors in isolation. This limits examination of factors, including interactions between code-related and oral-language precursors, facilitating — or inhibiting — biliteracy development (Castles \& Colthart, 2004; Lonigan, 2007).

\section{Summary and Future Directions}

This review screened 33 studies, identifying 17 literacy precursors, which-apart from semantic awareness - were significantly associated with word/non-word reading and/or text reading comprehension in simultaneous bilinguals. These include precursors also used in 
medRxiv preprint doi: https://doi.org/10.1101/2021.08.18.21262243; this version posted August 23, 2021. The copyright holder for this preprint (which was not certified by peer review) is the author/funder, who has granted medRxiv a license to display the preprint in perpetuity.

It is made available under a CC-BY-NC-ND 4.0 International license .

\section{PRECURSORS OF BILINGUAL LITERACY DEVELOPMENT}

monolingual children ${ }^{21}$, in addition to less commonly used precursors ${ }^{22}$. Phonological awareness and vocabulary were commonly-assessed precursors consistently associated with reading, across languages. To address the evident English assessment bias, future research should:

- Develop language-specific ${ }^{23}$ precursor screening tools across spoken languages.

- Examine reliability of non-linguistic precursors, including environmental print awareness working memory and non-verbal intelligence, when screening tools are not available in both languages.

- Report (and include in analyses) adequate and detailed language background measures across both languages, to understand the contribution of linguistic factors (e.g., language balance/dominance, proficiency, etc.) to literacy development in bilinguals.

- Examine precursors (e.g., code-related vs. oral-language skills) best suited for early screening/identification of specific reading difficulties (e.g., word/non-word reading compared to text comprehension) in biliteracy development.

- Examine interactions between various precursors, along with individual and combined contributions to reading, in linguistically-diverse bilinguals across proficiency profiles. Such research would contribute to reading models, such as SVR, Dual Route Model of Reading, $L I H$ and $S D H$, predominantly based on monolingual alphabetic readers.

${ }^{21}$ The literacy precursors commonly assessed in English-speaking monolingual children are: code-related skills (phonological awareness, letter knowledge, serial recall), oral language and grammar skills (oral language/linguistic comprehension, vocabulary, grammar [morphological and syntactic awareness]), domain-general cognitive skills (memory, non-verbal intelligence), and word/non-word decoding.

${ }^{22}$ The additional literacy precursors identified in this review are: semantic awareness, spelling, VA span, orthographic processing skills, environmental print awareness, name writing, sublexical/phonological speech perception and sentence priming.

${ }^{23}$ Based on phonological and orthographic properties. 
medRxiv preprint doi: https://doi.org/10.1101/2021.08.18.21262243; this version posted August 23, 2021. The copyright holder for this preprint (which was not certified by peer review) is the author/funder, who has granted medRxiv a license to display the preprint in perpetuity. It is made available under a CC-BY-NC-ND 4.0 International license .

\section{PRECURSORS OF BILINGUAL LITERACY DEVELOPMENT}

\section{References}

Adesope, O. O., Lavin, T., Thompson, T., \& Ungerleider, C. (2010). A systematic review and meta-analysis of the cognitive correlates of bilingualism. Review of Educational Research, 80(2), 207-245.

Adlof, S., Catts, H., \& Lee, J. (2010). Kindergarten predictors of second vs. eighth grade reading comprehension impairments. Journal of Learning Disabilities, 43, 332-345. https://dx.doi.org/10.1177\%2F0022219410369067

Akoglu, H. (2018). User's guide to correlation coefficients. Turkish Journal of Emergency Medicine, 18(3), 91-93. https://doi.org/10.1016/j.tjem.2018.08.001

August, D., \& Shanahan, T. (2006). Developing literacy in second-language learners: Report of the National Literacy Panel on Language-Minority Children and Youth. Routledge.

Bengochea, A., Justice, L. M., \& Hijlkema, M. J. (2017). Print knowledge in Yucatec MayaSpanish bilingual children: An initial inquiry. International Journal of Bilingual Education and Bilingualism, 20(7), 807-822. http://dx.doi.org/10.1080/13670050.2015.1103699

Bérubé, D., \& Marinova-Todd, S. (2012). The development of language and reading skills in the second and third languages of multilingual children in French immersion. International Journal of Multilingualism 9, 272-293. https://doi.org/10.1080/14790718.2011.631708

Bialystok, E., Luk, G., \& Kwan, E. (2005). Bilingualism, biliteracy, and learning to read: Interactions among languages and writing systems. Scientific Studies of Reading, 9(1), 43-61. https://doi.org/10.1207/s1532799xssr0901_4

Birgisdottir, F., Gestsdottir, S., \& Geldhof, G. J. (2020). Early predictors of first and fourth grade reading and math: The role of self-regulation and early literacy skills. Early Childhood Research Quarterly, 53, 507-519. https://doi.org/10.1016/j.ecresq.2020.05.001

Blom, E., Boerma, T., Bosma, E., Cornips, L., van den Heuij, K., \& Timmermeister, M. (2020). Cross-language distance influences receptive vocabulary outcomes of bilingual children. First Language, 40(2), 151-171. https://doi.org/10.1177\%2F0142723719892794

Blom, E., Küntay, A. C., Messer, M., Verhagen, J., \& Leseman, P. (2014). The benefits of being bilingual: Working memory in bilingual Turkish-Dutch children. Journal of Experimental Child Psychology, 128, 105-119. https://doi.org/10.1016/j.jecp.2014.06.007

Bosse, M. L., \& Valdois, S. (2009). Influence of the visual attention span on child reading performance: a cross-sectional study. Journal of Research in Reading, 32(2), 230-253. https://doi.org/10.1111/j.1467-9817.2008.01387.x

Both-de Vries, A. C., \& Bus, A. G. (2010). The proper name as starting point for basic reading skills. Reading and Writing, 23(2), 173-187. https://dx.doi.org/10.1007\%2Fs11145-008$\underline{9158-2}$

Caravolas, M., Lervåg, A., Mikulajová, M., Defior, S., Seidlová-Málková, G., \& Hulme, C. (2019). A cross-linguistic, longitudinal study of the foundations of decoding and 
medRxiv preprint doi: https://doi.org/10.1101/2021.08.18.21262243; this version posted August 23, 2021. The copyright holder for this preprint (which was not certified by peer review) is the author/funder, who has granted medRxiv a license to display the preprint in perpetuity. It is made available under a CC-BY-NC-ND 4.0 International license .

\section{PRECURSORS OF BILINGUAL LITERACY DEVELOPMENT}

reading comprehension ability. Scientific Studies of Reading, 23 (5), 386-402. https://doi.org/10.1080/10888438.2019.1580284

Castles, A., \& Coltheart, M. (2004). Is there a causal link from phonological awareness to success in learning to read? Cognition, 91(1), 77-111. https://doi.org/10.1016/S0010$\underline{0277(03) 00164-1}$

Castles, A., Rastle, K., \& Nation, K. (2018). Ending the reading wars: Reading acquisition from novice to expert. Psychological Science in the Public Interest, 19(1), 5-51. https://doi.org/10.1177\%2F1529100618772271

Cherodath, S., \& Singh, N. C. (2015). The influence of orthographic depth on reading networks in simultaneous biliterate children. Brain and Language, 143, 42-51. https://dx.doi.org/10.1016/j.bandl.2015.02.001

Chiappe, P., Siegel, L. S., \& Gottardo, A. (2002). Reading-related skills of kindergartners from diverse linguistic backgrounds. Applied Psycholinguistics, 23(1), 95-116. https://dx.doi.org/10.1017/S014271640200005X

Chung, W. L., \& Bidelman, G. M. (2021). Mandarin-speaking preschoolers’ pitch discrimination, prosodic and phonological awareness, and their relation to receptive vocabulary and reading abilities. Reading and Writing, 34(2), 337-353. https://doi.org/10.1007/s11145-020-10075-9

The Cochrane Collaboration. (2011). Cochrane handbook for systematic reviews of interventions [Version 5.1.0, updated March 2011]. (J.P.T. Higgins \& S. Green, Eds.). Cochrane. www.handbook.cochrane.org.

D'angiulli, A., Siegel, L. S., \& Serra. E. (2001). The development of reading in English and Italian in bilingual children. Applied Psycholinguistics, 22 (4): 479-507. https://doi.org/10.1017/S0142716401004015

Daniels, P. T., \& Share, D. L. (2018). Writing system variation and its consequences for reading and dyslexia. Scientific Studies of Reading, 22(1), 101-116. https://doi.org/10.1080/10888438.2017.1379082

De Bruin, A. (2019). Not all bilinguals are the same: A call for more detailed assessments and descriptions of bilingual experiences. Behavioral Sciences, 9(3), 33. https://doi.org/10.3390/bs9030033

De Bruin, A., Carreiras, M., \& Duñabeitia, J. A. (2017). The BEST dataset of language proficiency. Frontiers in psychology, 8, 522. https://doi.org/10.3389/fpsyg.2017.00522

Defior S. (2004) Phonological Awareness and Learning to Read: A Cross-Linguistic Perspective. In: Nunes T., Bryant P. (eds) Handbook of Children's Literacy. Springer, Dordrecht. https://doi.org/10.1007/978-94-017-1731-1_33

Dong, Y., Tang, Y., Chow, B. W. Y., Wang, W., \& Dong, W. Y. (2020). Contribution of vocabulary knowledge to reading comprehension among Chinese students: A metaanalysis. Frontiers in Psychology, 11, 2349. https://doi.org/10.3389/fpsyg.2020.525369 
medRxiv preprint doi: https://doi.org/10.1101/2021.08.18.21262243; this version posted August 23, 2021. The copyright holder for this preprint (which was not certified by peer review) is the author/funder, who has granted medRxiv a license to display the preprint in perpetuity. It is made available under a CC-BY-NC-ND 4.0 International license .

\section{PRECURSORS OF BILINGUAL LITERACY DEVELOPMENT}

Dunn, D.M., Hammer, C., \& Lawrence, F. R. (2011). Associations between preschool language and first grade reading outcomes in bilingual children. Journal of Communication Disorders, 44(4), 444-458. https://doi.org/10.1016/j.jcomdis.2011.02.003

Ellis, N. C., \& Hooper, A. M. (2001). Why learning to read is easier in Welsh than in English: Orthographic transparency effects evinced with frequency-matched tests. Applied Psycholinguistics, 22, 571-599. https://doi.org/10.1017/S0142716401004052

Foorman, B. R., Herrera, S., Petscher, Y., Mitchell, A., \& Truckenmiller, A. (2015). The structure of oral language and reading and their relation to comprehension in kindergarten through Grade 2. Reading and Writing, 28(5), 655-681. https://doi.org/10.1007/s11145$\underline{015-9544-5}$

Friesen, D. C., \& Bialystok, E. (2012). Metalinguistic ability in bilingual children: The role of executive control. Rivista Di Psicolinguistica Applicata, 12(3), 47.

Furnes, B., \& Samuelsson, S. (2010). Predicting reading and spelling difficulties in transparent and opaque orthographies: a comparison between Scandinavian and US/Australian children. Dyslexia, 16(2), 119-142. https://doi.org/10.1002/dys.401

García, J. R., \& Cain, K. (2014). Decoding and reading comprehension: A meta-analysis to identify which reader and assessment characteristics influence the strength of the relationship in English. Review of Educational Research, 84, 74-111. https://www.jstor.org/stable/24434229

Geva, E., Siegel, L.S. (2000). Orthographic and cognitive factors in the concurrent development of basic reading skills in two languages. Reading and Writing (12), 1-30. https://doi.org/10.1023/A:1008017710115

Gibson, T. A., Peña, E. D., \& Bedore, L. M. (2014). The receptive-expressive gap in bilingual children with and without primary language impairment. American Journal of SpeechLanguage Pathology, 23(4), 655-667. https://doi.org/10.1044/2014 AJSLP-12-0119

Grosjean, F. (2010). Bilingual: Life and reality. Cambridge, MA: Harvard University Press.

Gupta, A., \& Jamal, G. (2007). Reading strategies of bilingual normally progressing and dyslexic readers in Hindi and English. Applied Psycholinguistics, 28(1), 47-68

Haman, E., Wodniecka, Z., Marecka, M., Szewczyk, J., Białecka-Pikul, M., Otwinowska, A., Mieszkowska, K., Łuniewska, M., Kołak, J., Miękisz, A., \& Kacprzak, A. (2017). How does L1 and L2 exposure impact L1 performance in bilingual children? Evidence from Polish-English migrants to the United Kingdom. Frontiers in Psychology, 8, 1444. https://doi.org/10.3389/fpsyg.2017.01444

Hammer, C.S., Lawrence, F. R., \& Miccio, A. W. (2007). Bilingual children's language abilities and early reading outcomes in head start and kindergarten. Language, Speech \& Hearing Services in Schools, 38(3), 237-48. https://doi.org/10.1044/0161-1461(2007/025)

Hipfner-Boucher, K., Lam, K., \& Chen, X. (2014). The effects of bilingual education on the English language and literacy outcomes of Chinese-speaking children. Written Language and Literacy, 17(1), 116-138. https://doi.org/10.1075/wll.17.1.06hip 
medRxiv preprint doi: https://doi.org/10.1101/2021.08.18.21262243; this version posted August 23, 2021. The copyright holder for this preprint (which was not certified by peer review) is the author/funder, who has granted medRxiv a license to display the preprint in perpetuity. It is made available under a CC-BY-NC-ND 4.0 International license .

\section{PRECURSORS OF BILINGUAL LITERACY DEVELOPMENT}

Hjetland, H. N., Brinchmann, E. I., Scherer, R., \& Melby-Lervåg, M. (2017). Preschool predictors of later reading comprehension ability: A systematic review. Campbell Systematic Reviews, 14, 1-156. https://doi.org/10.4073/csr.2017.14

Hjetland, H. N., Brinchmann, E. I., Scherer, R., Hulme, C., \& Melby-Lervåg, M. (2020). Preschool pathways to reading comprehension: A systematic meta-analytic review. Educational Research Review, 30, 100323. https://doi.org/10.1016/j.edurev.2020.100323

Hsu, L. S., Ip, K. I., Arredondo, M. M., Tardif, T., \& Kovelman, I. (2019). Simultaneous acquisition of English and Chinese impacts children's reliance on vocabulary, morphological and phonological awareness for reading in English. International Journal of Bilingual Education and Bilingualism, 22(2), 207-223. https://dx.doi.org/10.1080/13670050.2016.1246515

Hulme, C., Nash, H. M., Gooch, D., Lervåg, A., \& Snowling, M. J. (2015). The foundations of literacy development in children at familial risk of dyslexia. Psychological Science, 26, 1877-1886. https://doi.org/10.1177\%2F0956797615603702

Hulme, C., Zhou, L., Tong, X., Lervåg, A., \& Burgoyne, K. (2019). Learning to read in Chinese: Evidence for reciprocal relationships between word reading and oral language skills. Developmental Science, 22(1), e12745. https://doi.org/10.1111/desc.12745

Ibrahim, R., Eviatar, Z., \& Aharon-Peretz, J. (2007). Metalinguistic awareness and reading performance: A cross language comparison. Journal of Psycholinguistic Research, 36(4), 297-317. https://dx.doi.org/10.1007/s10936- 006-9046-3

Jackson, D., \& Turner, R. (2017). Power analysis for random-effects meta-analysis. Research Synthesis Methods, 8(3), 290-302. https://onlinelibrary.wiley.com/doi/pdfdirect/10.1002/jrsm.1240

Jasińska, K., Kaja, K., \& Petitto, L. A. (2018). Age of bilingual exposure is related to the contribution of phonological and semantic knowledge to successful reading development. Child Development, 89(1), 310-331. https://doi.org/10.1111/cdev.12745

Jasińska, K. K., Wolf, S., Jukes, M. C., \& Dubeck, M. M. (2019). Literacy acquisition in multilingual educational contexts: Evidence from Coastal Kenya. Developmental Science, 128(28). https://doi.org/10.1111/desc.12828

Joanna Briggs Institute. (2017). Critical appraisal checklist for quasi-experimental studies (nonrandomized experimental studies). Retrieved from https://joannabriggs.org/sites/default/ files/2019-05/JBI_Quasi-Experimental_Appraisal_Tool2017_0.pdf

Kalia, V., Lane, P. D., \& Wilbourn, M. P. (2018). Cognitive control and phonological awareness in the acquisition of second language vocabulary within the Spanish-English dual immersion context. Cognitive Development, 48, 176-189. https://doi.org/10.1016/j.cogdev.2018.08.010

Kim, Y. S. G., \& Piper, B. (2019). Cross-language transfer of reading skills: An empirical investigation of bidirectionality and the influence of instructional environments. Reading and Writing, 32(4), 839-871. https://doi.org/10.1007/s11145-018-9889-7 
medRxiv preprint doi: https://doi.org/10.1101/2021.08.18.21262243; this version posted August 23, 2021. The copyright holder for this preprint

(which was not certified by peer review) is the author/funder, who has granted medRxiv a license to display the preprint in perpetuity.

It is made available under a CC-BY-NC-ND 4.0 International license .

\section{PRECURSORS OF BILINGUAL LITERACY DEVELOPMENT}

Kirby, J. R., Desrochers, A., Roth, L., \& Lai, S. S. (2008). Longitudinal predictors of word reading development. Canadian Psychology/Psychologie Canadienne, 49(2), 103.

Kirby, J. R., Georgiou, G. K., Martinussen, R., \& Parrila, R. (2010). Naming speed and reading: From prediction to instruction. Reading Research Quarterly, 45(3), 341-362.

Kovelman, I., Baker, S. A., \& Petitto, L. A. (2008). Age of first bilingual language exposure as a new window into bilingual reading development. Bilingualism (Cambridge, England), 11(2), 203-223. https://doi.org/10.1017/S1366728908003386

Kovelman, I., Salah-Ud-Din, M., Berens, M. S., \& Petitto, L. (2015). “One glove does not fit all” in bilingual reading acquisition: Using the age of first bilingual language exposure to understand optimal contexts for reading success. Cogent Education, 2(1). doi:10.1080/2331186X.2015.1006504

Kroll, J. F., Bobb, S. C., \& Hoshino, N. (2014). Two languages in mind: Bilingualism as a tool to investigate language, cognition, and the brain. Current Directions in Psychological Science, 23(3), 159-163.

Kuo, L. J., Chen, Z., \& Ko, S. W. (2016). The impact of bilingual experience on the literacy development of struggling readers. Journal of Childhood \& Development Disorders, 2(2), 1-5. https://doi.org/10.4172/2472-1786.100009

Lallier, M., Valdois, S., Lassus-Sangosse, D., Prado, C., \& Kandel, S. (2014). Impact of orthographic transparency on typical and atypical reading development: Evidence in French-Spanish bilingual children. Research in Developmental Disabilities, 35(5), 1177 1190. https://dx.doi.org/10.1016/j.ridd.2014.01.021

Lam, K., Chen, X., Geva, E., Luo, Y. C., \& Li, H. (2012). The role of morphological awareness in reading achievement among young Chinese-speaking English language learners: A longitudinal study. Reading and Writing, 25(8), 1847-1872. https://doi.org/10.1007/s11145-011-9329-4

Lervåg, A., \& Aukrust, V. G. (2009). Vocabulary knowledge is a critical determinant of the difference in reading comprehension growth between first and second language learners." Journal of Child Psychology and Psychiatry, 51 (5): 612620. https://doi.org/10.1111/j.1469-7610.2009.02185.x

Lesaux, N. K., \& Geva, E. (2006). Synthesis: Development of Literacy in Language-Minority Students. In D. August \& T. Shanahan (Eds.), Developing literacy in second-language learners: Report of the National Literacy Panel on Language-Minority Children and Youth (p. 53-74). Lawrence Erlbaum Associates Publishers.

Limbird, C. K., Maluch, J. T., Rjosk, C., Stanat, P., \& Merkens, H. (2014). Differential growth patterns in emerging reading skills of Turkish-German bilingual and German monolingual primary school students. Reading and Writing, 27(5), 945-968. https://doi.org/10.1007/s11145-013-9477-9

Lonigan, C. J. (2007). Vocabulary development and the development of phonological awareness skills in preschool children. Vocabulary acquisition: Implications for reading comprehension, 15-31. 
medRxiv preprint doi: https://doi.org/10.1101/2021.08.18.21262243; this version posted August 23, 2021. The copyright holder for this preprint (which was not certified by peer review) is the author/funder, who has granted medRxiv a license to display the preprint in perpetuity. It is made available under a CC-BY-NC-ND 4.0 International license .

\section{PRECURSORS OF BILINGUAL LITERACY DEVELOPMENT}

Mak, K.C.L. (2014). Reading comprehension in Chinese-English bilingual children: A cognitive perspective. Masters Abstracts International 2014.

Melby-Lervåg, M., Lyster, S. A., \& Hulme, C. (2012). Phonological skills and their role in learning to read: a meta-analytic review. Psychological Bulletin, 138(2), 322-352. https://doi.org/10.1037/a0026744

McBride-Chang, C., Bialystok, E., Chong, K. K., \& Li, Y. (2004). Levels of phonological awareness in three cultures. Journal of Experimental Child Psychology, 89(2), 93-111. https://doi.org/10.1016/j.jecp.2004.05.001

Meir, N., \& Armon-Lotem, S. (2017). Independent and combined effects of socioeconomic status (SES) and bilingualism on children's vocabulary and verbal short-term memory. Frontiers in Psychology, 8, 1442. https://dx.doi.org/10.3389\%2Ffpsyg.2017.01442

Muter, V., Hulme, C., Snowling, M.J. \& Stevenson, J. (2004). Phonemes, rimes and language skills as foundations of early reading development: Evidence from a longitudinal study. Developmental Psychology, 40, 66--681. https://doi.org/10.1037/0012$\underline{1649.40 .5 .665}$

National Early Literacy Panel (NELP). (2008). Developing early literacy: Report of the National Early Literacy Panel. Washington, DC: National Center for Family Literacy. https://lincs.ed.gov/publications/pdf/NELPReport09.pdf

Nation, K., \& Snowling, M. J. (1998). Individual differences in contextual facilitation: Evidence from dyslexia and poor reading comprehension. Child Development, 69(4), 996-1011. https://doi.org/10.1111/j.1467-8624.1998.tb06157.x

Oakhill, J., \& Kyle, F. (2000). The relation between phonological awareness and working memory. Journal of Experimental Child Psychology, 75(2), 152-164. https://doi.org/10.1006/jecp.1999.2529

O'Brien, B. A., Mohamed, M. B. H., Yussof, N. T., \& Ng, S. C. (2019). The phonological awareness relation to early reading in English for three groups of simultaneous bilingual children. Reading and Writing: An Interdisciplinary Journal, 32(4), 909-937. https://dx.doi.org/10.1007/s11145-018-9890-1

Oller, D. K., Pearson, B. Z., \& Cobo-lewis, A. (2007). Profile effects in early bilingual language and literacy. Applied Psycholinguistics, 28(2), 191. https://dx.doi.org/10.1017/S0142716407070117

Patterson, J. (2002). Relationships of expressive vocabulary to frequency of reading and television experience among bilingual toddlers. Applied Psycholinguistics, 23(4), 493508. https://doi.org/10.1017/S0142716402004010

Peets, K. F., Yim, O., \& Bialystok, E. (2019). Language proficiency, reading comprehension and home literacy in bilingual children: The impact of context. International Journal of Bilingual Education and Bilingualism, 1-15. https://doi.org/10.1080/13670050.2019.1677551 
medRxiv preprint doi: https://doi.org/10.1101/2021.08.18.21262243; this version posted August 23, 2021. The copyright holder for this preprint (which was not certified by peer review) is the author/funder, who has granted medRxiv a license to display the preprint in perpetuity. It is made available under a CC-BY-NC-ND 4.0 International license .

\section{PRECURSORS OF BILINGUAL LITERACY DEVELOPMENT}

Ramirez, G., Chen, X., \& Pasquarella, A. (2013). Cross-linguistic transfer of morphological awareness in Spanish-speaking English language learners: The facilitating effect of cognate knowledge. Topics in Language Disorders, 33(1), 73-92. https://doi.org/10.1097/TLD.0b013e318280f55a

Rhys, M., \& Thomas, E. M. (2013). Bilingual Welsh-English children's acquisition of vocabulary and reading: Implications for bilingual education. International Journal of Bilingual Education and Bilingualism, 16(6), 633-656. https://dx.doi.org/10.1080/13670050.2012.706248

Richardson, W. S., Wilson, M. C., Nishikawa, J., \& Hayward, R. S. (1995). The well-built clinical question: a key to evidence-based decisions. ACP Journal Club, 123(3). https://doi.org/10.7326/ACPJC-1995-123-3-A12

Ríos-López, P., Molnar, M. T., Lizarazu, M., \& Lallier, M. (2017). The role of slow speech amplitude envelope for speech processing and reading development. Frontiers in Psychology, 8, 1497. https://dx.doi.org/10.3389\%2Ffpsyg.2017.01497

Ripamonti, E., Aggujaro, S., Molteni, F., Zonca, G., Frustaci, M., \& Luzzatti, C. (2014). The anatomical foundations of acquired reading disorders: a neuropsychological verification of the dual-route model of reading. Brain and Language, 134, 44-67. https://doi.org/10.1016/j.bandl.2014.04.001

Ritchie, S., \& Bates, T. (2013). Enduring links from childhood mathematics and reading achievement to adult socioeconomic status. Psychological Science, 24(7), 1301-1308. https://doi.org/10.1177\%2F0956797612466268

Ruan, Y., Georgiou, G. K., Song, S., Li, Y., \& Shu, H. (2018). Does writing system influence the associations between phonological awareness, morphological awareness, and reading? A meta-analysis. Journal of Educational Psychology, 110(2), 180. https://doi.apa.org/doi/10.1037/edu0000216

Ryan, C. (2013). Language use in the United States: 2011. American Community Survey Reports, $A C S-22$. U.S. Census Bureau, Washington, DC. Retrieved from https://www2.census.gov/library/publications/2013/acs/acs-22/acs-22.pdf

Schaars, M. M., Segers, E., \& Verhoeven, L. (2019). Cognitive and linguistic precursors of early first and second language reading development. Learning and Individual Differences, 72, 1-14. https://doi.org/10.1016/j.lindif.2019.03.008

Schmidt, F., \& Hunter, J. (2015). Methods of meta-analysis (Third Edition ed.). SAGE Publications, Ltd https://www.doi.org/10.4135/9781483398105

Spatgens, T., \& Schoonen, R. (2018). The semantic network, lexical access, and reading comprehension in monolingual and bilingual children: An individual differences study. Applied Psycholinguistics, 39(1), 225-256. https://dx.doi.org/10.1017/S0142716417000224

Spencer, L.H., \& Hanley, J.R. (2003), Effects of orthographic transparency on reading and phoneme awareness in children learning to read in Wales. British Journal of Psychology, 94: 1-28. https://doi.org/10.1348/000712603762842075 
medRxiv preprint doi: https://doi.org/10.1101/2021.08.18.21262243; this version posted August 23, 2021. The copyright holder for this preprint (which was not certified by peer review) is the author/funder, who has granted medRxiv a license to display the preprint in perpetuity. It is made available under a CC-BY-NC-ND 4.0 International license .

\section{PRECURSORS OF BILINGUAL LITERACY DEVELOPMENT}

Spencer, L. H., \& Hanley, J. R. (2004). Learning a transparent orthography at five years old: Reading development of children during their first year of formal reading instruction in Wales. Journal of Research in Reading, 27, 1-14. https://doi.org/10.1111/j.14679817.2004.00210.x

Sun, H., Bornstein, M.H., \& Esposito, G. (2021). The specificity principle in young dual language learners' English development. Child Development. https://doi.org/10.1111/cdev.13558

Tamis-LeMonda, C., Song, L., Luo, R., Kuchirko, Y., Kahana-Kalman, R., Yoshikawa, H., \& Raufman, J. (2014). Children's vocabulary growth in English and Spanish across early development and associations with school readiness skills. Developmental Neuropsychology, 39(2), 69-87. https://dx.doi.org/10.1080/87565641.2013.827198

Thordardottir, E. (2019). Amount trumps timing in bilingual vocabulary acquisition: Effects of input in simultaneous and sequential school-age bilinguals. International Journal of Bilingualism, 23(1), 236-255. https://doi.org/10.1177/1367006917722418

Tighe, E. L., Wagner, R. K., \& Schatschneider, C. (2015). Applying a multiple group causal indicator modeling framework to the reading comprehension skills of third, seventh, and tenth grade students. Reading and Writing, 28(4), 439-466. https://psycnet.apa.org/doi/10.1007/s11145-014-9532-1

Tong, X., Tong, X., \& McBride, C. (2017). Unpacking the relation between morphological awareness and Chinese word reading: Levels of morphological awareness and vocabulary. Contemporary Educational Psychology, 48, 167-178. https://doi.org/10.1016/j.cedpsych.2016.07.003

United Nations Educational, Scientific and Cultural Organization (UNESCO). (2017). More than one-half of children and adolescents are not learning worldwide. Retrieved from https://uis.unesco.org/sites/default/files/documents/fs46-more-than-half-children-notlearning-en2017.pdf

van den Bosch, L. J., Segers, E., \& Verhoeven, L. (2020). First and second language vocabulary affect early second language reading comprehension development. Journal of Research in Reading, 43(3), 290-308. https://doi.org/10.1111/1467-9817.12304

Vanvooren, S., Poelmans, H., De Vos, A., Ghesquière, P., \& Wouters, J. (2017). Do prereaders' auditory processing and speech perception predict later literacy? Research in Developmental Disabilities, 70, 138-151. https://psycnet.apa.org/doi/10.1016/j.ridd.2017.09.005

Vital, H., \& Karniol, R. (2011). Procedural versus narrative cross-language priming and bilingual children's reading and sentence sequencing of same genre and opposite genre text in the other language. Bilingualism, 14(4), 547-561. https://dx.doi.org/10.1017/S1366728910000520

Wood, C., Fitton, L., \& Rodriguez, E. (2018). Home literacy of dual-language learners in kindergarten from low-SES backgrounds. AERA Open. https://doi.org/10.1177/2332858418769613 
medRxiv preprint doi: https://doi.org/10.1101/2021.08.18.21262243; this version posted August 23, 2021. The copyright holder for this preprint (which was not certified by peer review) is the author/funder, who has granted medRxiv a license to display the preprint in perpetuity. It is made available under a CC-BY-NC-ND 4.0 International license .

\section{PRECURSORS OF BILINGUAL LITERACY DEVELOPMENT}

Yan, M., Li, Y., Sun, X., Zhou, X., Hui, Y., \& Li, H. (2021). The roles of decoding and vocabulary in Chinese reading development: Evidence from a 3-year longitudinal study. British Journal of Educational Psychology, 91(1), 300-314. https://bpspsychub.onlinelibrary.wiley.com/doi/epdf/10.1111/bjep.12365

Yang, F.Y. (2010). Biliteracy effects on phonological awareness, oral language proficiency and reading skills in Taiwanese Mandarin-English bilingual children. Dissertation Abstracts International, B: Sciences and Engineering 2010.

Yang, X \& Qiao, L. (2021). Effects of spatial skills and working memory on Chinese character reading in young children. Infant and Child Development, 11(12): 1-13. http://dx.doi.org/10.1002/icd.2231

Yeong, S. H. M., Fletcher, J., \& Bayliss, D. M. (2014). Importance of phonological and orthographic skills for English reading and spelling: A comparison of English monolingual and Mandarin-English bilingual children. Journal of Educational Psychology, 106(4), 1107. https://psycnet.apa.org/doi/10.1037/a0036927

Zhang, D. (2016). Morphology in Malay-English biliteracy acquisition: An intervention study. International Journal of Bilingual Education and Bilingualism, 19(5), 546-562. https://dx.doi.org/10.1080/13670050.2015.102687

Ziegler, J. C., Bertrand, D., Tóth, D., Csépe, V., Reis, A., Faísca, L., Saine, N., Lyytinen, H., Vaessen, A., \& Blomert, L. (2010). Orthographic depth and its impact on universal predictors of reading: a cross-language investigation. Psychological Science, 21(4), 551559. https://doi.org/10.1177/0956797610363406

Ziegler, J. C., \& Goswami, U. (2005). Reading acquisition, developmental dyslexia, and skilled reading across languages: a psycholinguistic grain size theory. Psychological Bulletin, 131(1), 3. https://doi.apa.org/doi/10.1037/0033-2909.131.1.3 


\section{It is made available under a CC-BY-NC-ND 4.0 International license. $\quad$ Appendices}

Appendix A. Tables and Figures for Systematic Literature Review and Meta-Analysis

Tables

\section{Table 1}

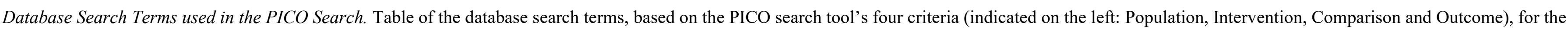
four Linguistics and Language Behavior Abstracts (LLBA), Educational Resources Information Center (ERIC), MLA International Bibliography (MLA) and PsycINFO (ProQuest) electronic databases.

PICO Tool Criteria

Linguistics and Language Behavior Abstracts (LLBA)

Database Search Terms

MLA International Bibliography PsycINFO (ProQuest) Information Center (MLA) (ERIC)

Population (P) mainsubject (Child*) OR mainsubject (Child*) OR$$
\text { ( }
$$

mainsubject (Child*) $O R$

mainsubject (Bilinguat*)

mainsubject (Bilingual*)

OR mainsubject

(Multilingual*) OR

mainsubject (Bilingual

$O R$ mainsubject

(Multilingual*) $O R$

mainsubject (Second

mainsubject (Infants) $A N D$

mainsubject (Child*) OR

mainsubject (Bilingual*) $O R$

mainsubject (Multilingual*) $O R$

mainsubject (Second Language

Learner*)

Language Learner*)

Language Learner*) mainsubject (Infants) $A N D$

mainsubject (Bilingual*) $O R$

mainsubject (Multilingual*)

Language Learner*)
OR mainsubject (Second 
PRECURSORS OF BILINGUAL LITERACY DEVELOPMENT

medRxiv preprint doi: https: $: / /$ doi. org/ $10.1101 / 2021.08 .18 .21262243$; this version posted August 23,2021 . The copyright holder for this preprint
(which was not certified by peer review) is the authorffunder, who has granted medRxiv a license to display the preprint in perpetuity.

Intervention

(Literacy Precursor

Assessed; I)

$A N D$
It is made available under a $\mathrm{CC}-\mathrm{BY}$-NC $\mathrm{g}-\mathrm{N}$
Phonological A Awareness

$O R$ phonem* awareness

$O R$ letter knowledge $O R$

grapheme knowledge $O R$

Grapheme Phoneme

Correspondence $O R$ sound

symbol* $O R$ Serial Recall

$O R$ Oral Comprehension

$O R$ Verbal

Comprehension $O R$

Listening Comprehension

$O R$ Vocabulary $O R$ Word

Knowledge $O R$ gramma

$O R$ Syntax $O R$ Syntac

OR Synta* $O R$

Morpholog* $O R$

Morphem* $O R$ Visual

Short Term Memory $O R$

Phonological Short Term

Memory $O R$ Short Term

Memory $O R$ Working

Memory $O R$ Visua

Memory $O R$ Verbal

Memory OR Nonverbal

Memory $O R$ Nonverbal

Ability $O R$ Nonverbal

Intelligence $O R$ Nonverba

IQ OR Precursor Literacy

$O R$ Precursor Reading $O R$

Predictor Literacy $O R$

Predictor Reading $O R$

Precursor Literacy Skills

$O R$ Precursors of Reading

Ability $O R$ Early

Predictors of Later

Conventional Literacy

Skills $O R$ Predictive

Literacy Skills $O R$

Predictors of Later

Reading Skills $O R$

Preschool Literacy honological Awareness

$O R$ phonem* awareness

$O R$ letter knowledge $O R$

grapheme knowledge $O R$

Grapheme Phoneme

Correspondence $O R$ sound sound symbol* $O R$ Serial Recall

symbol* $O R$ Serial Recall $O R$ Oral Comprehension $O R$

Corbal

Comprehension $O R$

Knowledge $O R$ grammar $O R$

$O R$ Vocabulary $O R$ Word Syntax $O R$ Syntac* $O R$ Synta*

Knowledge $O R$ grammar $O R$ Morpholog* OR Morphem*

$O R$ Syntax $O R$ Syntac*

$O R$ Synta* $O R$

Morpholog* $O R$

Morphem* $O R$ Visual

Short Term Memory $O R$

Phonological Short Term

Memory $O R$ Short Term

Memory $O R$ Working

Memory $O R$ Visual

Memory $O R$ Verbal

Memory OR Nonverba

Memory $O R$ Nonverbal

Ability $O R$ Nonverbal

telligence $O R$ Nonverba

Q $O R$ Precursor Literacy

$O R$ Precursor Reading $O R$

Predictor Literacy $O R$

Predictor Reading $O R$

$O R$ Precursors of Reading

Ability $O R$ Early

Predictors of Later

Conventional Literacy

Skills $O R$ Predictive

Literacy Skills $O R$

Predictors of Late

Reading Skills $O R$

Preschool Literacy phonem* awareness $O R$ letter

knowledge $O R$ grapheme

knowledge $O R$ Grapheme

Phoneme Correspondence $O R$

Verbal Comprehension $O R$

Listening Comprehension $O R$

Vocabulary $O R$ Word

Phonological Awareness $O R$

phonem* awareness $O R$

letter knowledge $O R$

grapheme knowledge $O R$

Grapheme Phoneme

Correspondence $O R$ sound

symbol* $O R$ Serial Recall

$O R$ Oral Comprehension $O R$

Verbal Comprehension $O R$

istening Comprehension

$O R$ Vocabulary $O R$ Word

Knowledge $O R$ grammar $O R$

Syntax $O R$ Syntac* $O R$

$O R$ Visual Short Term Memory Synta* OR Morpholog* $O R$

$O R$ Phonological Short Term Morphem* $O R$ Visual Short

Memory $O R$ Short Term Memory Term Memory $O R$

$O R$ Working Memory $O R$ Visual Phonological Short Term

Memory $O R$ Verbal Memory OR Memory $O R$ Short Term

Nonverbal Memory $O R \quad$ Memory $O R$ Working

Nonverbal Ability $O R$ Nonverbal Memory $O R$ Visual Memory Intelligence $O R$ Nonverbal IQ $O R$ Verbal Memory OR

$O R$ Precursor Literacy $O R \quad$ Nonverbal Memory $O R$

Precursor Reading $O R$ Predictor Nonverbal Ability $O R$

Literacy $O R$ Predictor Reading Nonverbal Intelligence $O R$

$O R$ Precursor Literacy Skills $O R \quad$ Nonverbal IQ $O R$ Precursor

Precursors of Reading Ability $O R$ Literacy $O R$ Precursor

Reading $O R$ Predictor

Conventional Literacy Skills $O R \quad$ Literacy $O R$ Predictor

Predictive Literacy Skills $O R \quad$ Reading $O R$ Precursor

Predictors of Later Reading

Skills OR Preschool Literacy

Literacy Skills $O R$

Precursors of Reading

Ability $O R$ Early Predictors

of Later Conventional

Literacy Skills $O R$ Predictive

Literacy Skills $O R$ Predictors

of Later Reading Skills $O R$

Preschool Literacy 
PRECURSORS OF BILINGUAL LITERACY DEVELOPMENT

medRxiv preprint doi: https:///doi. org/10.1101/2021.08.18.21262243; this version posted August 23, 2021. The copyright holder for this preprin
(which was not certified by peer review) is the authorffunder, who has granted medRxiv a license to display the preprint in perpetuity.

$A N D$

Outcome (O)

Word Decoding $O R$

Reading Fluency $O R$

Word Recognition $O R$

Reading Ability $O R$

Reading Skills $O R$

Literacy Skills OR

Reading Comprehension
Word Decoding $O R$

Reading Fluency $O R$

Word Recognition $O R$

Reading Ability $O R$

Reading Skills $O R$

Literacy Skills $O R$

Reading Comprehension
Word Decoding $O R$ Reading

Fluency $O R$ Word Recognition

$O R$ Reading Ability $O R$ Readin

Skills $O R$ Literacy Skills $O R$

Reading Comprehension

oding $O R$ Reading

uency $O R$ Word

Recognition $O R$ Reading

Ability $O R$ Reading Skills

$O R$ Literacy Skills $O R$

Reading Comprehensio

Note. PICO = Population, Intervention, Comparison and Outcome; $A N D=$ mandatory search terms; $O R=$ optional search terms; * = truncation symbol to retrieve multiple search terms with a common root in the Linguistics and Language Behavior Abstracts, Educational Resources Information Center, MLA International Bibliography and PsycINFO (ProQuest) databases; N/A = not applicable. 


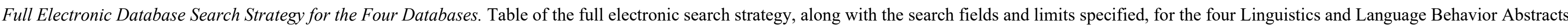
(LLBA), Educational Resources Information Center (ERIC), MLA International Bibliography (MLA) and PsycINFO (ProQuest) databases.

\section{Database Search Terms}

Search Search

Fields Limits
Linguistics and Language Behavior Abstracts (LLBA)

(Phonological Awareness $O R$ phonem* awareness $O R$ letter knowledge $O R$ grapheme knowledge $O R$ Grapheme Phoneme Correspondence $O R$ sound symbol* OR Serial Recall $O R$ Oral Comprehension $O R$ Verbal Comprehension $O R$ Listening Comprehension $O R$ Vocabulary $O R$ Word Knowledge $O R$ grammar $O R$ Syntax $O R$ Syntac* $O R$ Synta* $O R$

Morpholog* OR Morphem* $O R$ Visual Short Term Memory $O R$ Phonological Short Term Memory Working Memory $O R$ Visual Memory $O R$ Verbal Memory OR Nonverbal Memory $O R$ Nonverbal Ability $O R$ Nonverbal Intelligence $O R$ Nonverbal IQ $O R$ Precursor Literacy $O R$ Precursor Reading $O R$ Predictor Literacy $O R$ Predictor Skills $O R$ Precursors of Reading Ability $O R$ Early Predictors of Later Conventional Literacy Skills $O R$ Predictive Literacy Skills $O R$ Predictors of Later Reading Skills $O R$ Preschool Literacy) $A N D$

(Word Decoding OR Reading

Fluency $O R$ Word Recognition $O R$ Reading Ability $O R$ Reading Skills $O R$ Literacy Skills $O R$ Reading

Comprehension) $A N D$ mainsubject (Child* OR Infants) $O R$ Short Term Memory $O R$ Reading $O R$ Precursor Literacy
Educational Resources Information Center (ERIC)

(Phonological Awareness $O R$ phonem*
awareness $O R$ letter knowledge $O R$ grapheme knowledge $O R$ Grapheme Phoneme Correspondence $O R$ sound symbol* $O R$ Serial Recall $O R$ Oral Comprehension $O R$ Verbal Comprehension $O R$ Listening Comprehension $O R$ Vocabulary $O R$ Word Knowledge $O R$ grammar $O R$ Syntax $O R$ Syntac* $O R$ Synta* $O R$ Morpholog* OR Morphem* OR Visu Short Term Memory $O R$ Phonological Short Term Memory $O R$ Short Term Memory $O R$ Working Memory $O R$ Visual Memory $O R$ Verbal Memory OR Nonverbal Memory $O R$ Nonverb Ability $O R$ Nonverbal Intelligence $O R$ Nonverbal IQ $O R$ Precursor Literacy $O R$ Precursor Reading $O R$ Predictor Literacy $O R$ Predictor Reading $O R$ Precursor Literacy Skills $O R$ Precursor of Reading Ability $O R$ Early Predictors of Later Conventional Literacy Skills $O R$ Predictive Literacy Skills $O R$ Predictors of Later Reading Skills $O R$ Preschool Literacy) $A N D$ (Word

Decoding $O R$ Reading Fluency $O R$

Word Recognition $O R$ Reading Ability $O R$ Reading Skills $O R$ Literacy Skills $O R$ Reading Comprehension) $A N D$ mainsubject (Child* OR Infants) $A N D$ mainsubject (Bilingual* $O R$ Multilingual* $O R$ Second Language Learner*)
MLA International Bibliography PsycINFO (ProQuest) (MLA)

Phonological Awareness $O R$ phonem* awareness $O R$ letter knowledge $O R$ grapheme knowledge $O R$ Grapheme Phoneme Correspondence $O R$ sound symbol* OR Serial Recal $O R$ Oral Comprehension $O R$

Verbal Comprehension $O R$ Listening Comprehension $O R$ Vocabulary $O R$ Word Knowledge $O R$ grammar $O R$ Syntax $O R$ Syntac* $O R$ Synta* $O R$

Morpholog* OR Morphem* OR Visual Short Term Memory $O R$ Phonological Short Term Memory $O R$ Short Term Memory $O R$ Working Memory $O R$ Visual Memory $O R$ Verbal Memory OR Nonverbal Memory $O R$ Nonverbal Ability $O R$ Nonverba Intelligence $O R$ Nonverbal IQ $O R$ Precursor Literacy $O R$ Precurso Reading $O R$ Predictor Literacy $O R$ Predictor Reading $O R$ Precursor Literacy Skills $O R$ Precursors of Reading Ability $O R$ Early Predictors of Later

Conventional Literacy Skills $O R$ Predictive Literacy Skills $O R$ Predictors of Later Reading Skills $O R$ Preschool Literacy) $A N D$ (Word Decoding $O R$ Reading Fluency $O R$ Word Recognition $O R$ Reading Ability $O R$ Reading Skills $O R$ Literacy Skills $O R$ Reading Comprehension)
(Phonological Awareness $O R$ phonem* awareness $O R$ lette knowledge $O R$ grapheme knowledge $O R$ Grapheme Phoneme Correspondence $O R$ sound symbol* $O R$ Serial Recall $O R$ Oral Comprehension $O R$ Verbal Comprehension $O R$ Listening Comprehension $O R$ Vocabulary $O R$ Word Knowledge $O R$ grammar $O R$ Syntax $O R$ Syntac* OR Synta* OR

Morpholog* OR Morphem* OR Visual Short Term Memory $O R$ Phonological Short Term Memory $O R$ Short Term Memory $O R$ Working Memory $O R$ Visual Memory $O R$ Verbal Memory OR Nonverbal Memory $O R$ Nonverbal Ability $O R$ Nonverbal Intelligence $O R$ Nonverbal IQ $O R$ Precursor Literacy $O R$ Precursor Reading $O R$ Predictor Literacy $O R$ Predictor Reading $O R$ Precursor Literacy Skills $O R$ Precursors of eading Ability $O R$ Early Predictors of Later Conventiona Literacy Skills $O R$ Predictive Literacy Skills $O R$ Predictors of Later Reading Skills $O R$ Preschoo Literacy) $A N D$ (Word Decoding $O R$ Reading Fluency $O R$ Word Recognition $O R$ Reading Ability $O R$ Reading Skills $O R$ Literacy

Skills $O R$ Reading Comprehension) 
PRECURSORS OF BILINGUAL LITERACY DEVELOPMENT

medRxiv preprint doi: hitps:///doi.org/10.1101/2021.08.18.21262243; this version posted August 23, 2021. The copyright holder for this preprint
(which was not certified by peer review) is the authorffunder, who has granted medRxiv a license to display the preprint in perpetuity.

\begin{tabular}{lll}
\hline$A N D$ mainsubject (Bilingual* OR & $A N D$ mainsubject (Child* OR & $A N D$ mainsubject (Child* OR \\
Multilingual* $O R$ Second & Infants) $A N D$ mainsubject & Infants) $A N D$ mainsubject
\end{tabular}

Language Learner*)

(Bilingual* OR Multilingual* OR (Bilingual* OR Multilingual* OR

Second Language Learner*) Second Language Learner*)

Note. $A N D=$ mandatory search terms; $O R=$ optional search terms; $*=$ truncation symbol to retrieve multiple search terms with a common root in the Linguistics and Language Behavior Abstracts, Educational Resources Information Center, MLA International Bibliography and PsycINFO (ProQuest) electronic databases. 
PRECURSORS OF BILINGUAL LITERACY DEVELOPMENT

medRxiv preprint doi: https:///doi.org/10.1101/2021.08.18.221262243; this version posted August 23, 2021. The copyright holder for this preprint
(which was not certified by peer review) is the authorffunder, who has granted medRxiv a license to display the preprint in perpetuity.

Table 3

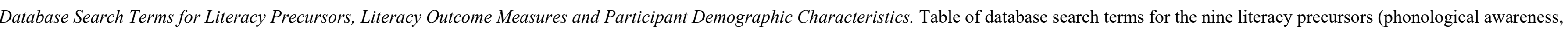
letter knowledge, serial recall, oral language/listening comprehension, vocabulary, grammar, memory, non-verbal intelligence and word decoding) and general literacy precursors, two literacy outcome measures (word/non-word reading and text reading comprehension) and participant characteristics (age and type of language background) for the four Linguistics and Language Behavior Abstracts (LLBA), Educational Resources Information Center (ERIC), MLA International Bibliography (MLA) and PsycINFO (ProQuest) databases.

\begin{tabular}{|c|c|c|c|c|c|c|c|c|c|c|}
\hline $\begin{array}{c}\text { Literacy } \\
\text { Precursors }\end{array}$ & $\begin{array}{l}\text { Phonological } \\
\text { Awareness }\end{array}$ & $\begin{array}{c}\text { Letter } \\
\text { Knowledge }\end{array}$ & $\begin{array}{l}\text { Serial } \\
\text { Recall }\end{array}$ & $\begin{array}{l}\text { Oral } \\
\text { Language/Liste } \\
\text { ning } \\
\text { Comprehension }\end{array}$ & Vocabulary & Grammar & Memory & $\begin{array}{l}\text { Non-Verbal } \\
\text { Intelligence }\end{array}$ & $\begin{array}{c}\text { Word } \\
\text { Decoding }\end{array}$ & $\begin{array}{c}\text { General Literacy } \\
\text { Precursors }\end{array}$ \\
\hline \multirow[t]{5}{*}{$\begin{array}{l}\text { Search } \\
\text { Query }\end{array}$} & $\begin{array}{l}\text { Phonological } \\
\text { Awareness }\end{array}$ & $\begin{array}{l}\text { Letter } \\
\text { Knowledge }\end{array}$ & $\begin{array}{l}\text { Serial } \\
\text { Recall }\end{array}$ & $\begin{array}{l}\text { Oral } \\
\text { Comprehension }\end{array}$ & Vocabulary & Grammar & $\begin{array}{l}\text { Visual Short } \\
\text { Term } \\
\text { Memory }\end{array}$ & $\begin{array}{l}\text { Nonverbal } \\
\text { Ability }\end{array}$ & Word Decoding & Precursor Literacy \\
\hline & $\begin{array}{l}\text { Phonem* } \\
\text { Awareness }\end{array}$ & $\begin{array}{l}\text { Grapheme } \\
\text { Knowledge }\end{array}$ & & $\begin{array}{l}\text { Verbal } \\
\text { Comprehension }\end{array}$ & $\begin{array}{l}\text { Word } \\
\text { Knowledge }\end{array}$ & Syntax & $\begin{array}{l}\text { Phonological } \\
\text { Short Term } \\
\text { Memory }\end{array}$ & $\begin{array}{l}\text { Nonverbal } \\
\text { Intelligence }\end{array}$ & $\begin{array}{l}\text { Reading } \\
\text { Fluency }\end{array}$ & Precursor Reading \\
\hline & & $\begin{array}{l}\text { Phoneme } \\
\text { Grapheme } \\
\text { Correspond } \\
\text { ence }\end{array}$ & & $\begin{array}{l}\text { Listening } \\
\text { Comprehension }\end{array}$ & & Syntac* & $\begin{array}{l}\text { Short Term } \\
\text { Memory }\end{array}$ & Nonverbal IQ & $\begin{array}{l}\text { Word } \\
\text { Recognition }\end{array}$ & Predictor Literacy \\
\hline & & $\begin{array}{l}\text { Sound } \\
\text { Symbol* }\end{array}$ & & & & Synta* & $\begin{array}{l}\text { Working } \\
\text { Memory }\end{array}$ & & Reading Ability & Predictor Reading \\
\hline & & & & & & $\begin{array}{l}\text { Morpholog } \\
*\end{array}$ & $\begin{array}{l}\text { Visual } \\
\text { Memory }\end{array}$ & & Reading Skills & $\begin{array}{l}\text { Precursor Literacy } \\
\text { Skills }\end{array}$ \\
\hline $\begin{array}{l}\text { Literacy } \\
\text { Precursors }\end{array}$ & $\begin{array}{l}\text { Phonological } \\
\text { Awareness }\end{array}$ & $\begin{array}{c}\text { Letter } \\
\text { Knowledge }\end{array}$ & $\begin{array}{l}\text { Serial } \\
\text { Recall }\end{array}$ & $\begin{array}{l}\text { Oral Language/ } \\
\text { Listening } \\
\text { Comprehension }\end{array}$ & Vocabulary & Grammar & Memory & $\begin{array}{l}\text { Non-Verbal } \\
\text { Intelligence }\end{array}$ & $\begin{array}{c}\text { Word } \\
\text { Decoding }\end{array}$ & $\begin{array}{c}\text { General Literacy } \\
\text { Precursors }\end{array}$ \\
\hline $\begin{array}{l}\text { Search } \\
\text { Query }\end{array}$ & & & & & & & $\begin{array}{l}\text { Nonverbal } \\
\text { Memory }\end{array}$ & & & $\begin{array}{l}\text { Early Predictors of } \\
\text { Later Conventional } \\
\text { Literacy Skills }\end{array}$ \\
\hline
\end{tabular}


PRECURSORS OF BILINGUAL LITERACY DEVELOPMENT

medRxiv preprint doi: https:///doi.org/10.1101/2021.08. 18.21262243; this version posted August 23, 2021. The copyright holder for this preprint
(which was not certified by peer review) is the authorffunder, who has granted medRxiv a license to display the preprint in perpetuity.

Predictive Literacy

Skills

Predictors of

Later

Reading

Skills

Preschool

Literacy

\begin{tabular}{lll}
\hline Literacy Outcomes & Word/Non-Word Decoding Or Reading & Reading Comprehension \\
\hline Search Query & Word Decoding & Reading Comprehension \\
& Reading Fluency & \\
& Word Recognition & \\
& Reading Ability & \\
& Reading Skills & \\
& Literacy Skills & Type of Language Background (Multilinguals/Bilinguals) \\
\hline Participant Demographic & Age Demographic (Children) & \\
Characteristics & Child* & Bilingual* \\
\hline Search Query & Infants & Multilingual* \\
& & Second Language Learner*
\end{tabular}

Note. ${ }^{*}=$ truncation symbol to retrieve multiple search terms with a common root in the electronic databases. 
PRECURSORS OF BILINGUAL LITERACY DEVELOPMENT

medRxiv preprint doi: https:///doi.org/10.1101/2021.08. 18.21262243; this version posted August 23, 2021. The copyright holder for this preprint
(which was not certified by peer review) is the authorffunder, who has granted medRxiv a license to display the preprint in perpetuity.

Table 4

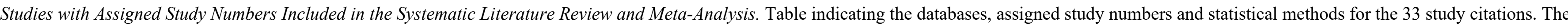
study numbers in Tables 5, 6, 7, 8A, 8B, 9, 10,11, 12 and 13 will refer to the corresponding citations in Table 4.

\begin{tabular}{ll}
\hline Database & \multicolumn{1}{c}{ Reference } \\
\hline LLBA & $\begin{array}{l}\text { Hipfner-Boucher, K., Lam, K., \& Chen, X. (2014). The effects of bilingual education } \\
\text { on the English language and literacy outcomes of Chinese-speaking children. Written } \\
\text { Language and Literacy, 17(1), 116-138. }\end{array}$ \\
& $\begin{array}{l}\text { Yeong, S. H. M., Fletcher, J., \& Bayliss, D. M. (2014). Importance of phonological } \\
\text { and orthographic skills for English reading and spelling: A comparison of English } \\
\text { monolingual and Mandarin-English bilingual children. Journal of Educational }\end{array}$
\end{tabular}

Psychology, 106(4), 1107

LLBA

Hsu, L. S., Ip, K. I., Arredondo, M. M., Tardif, T., \& Kovelman, I. (2019). Simultaneous acquisition of English and Chinese impacts children's reliance on vocabulary, morphological and phonological awareness for reading in English International Journal of Bilingual Education and Bilingualism, 22(2), 207-223. doi:http://dx.doi.org/10.1080/13670050.2016.1246515

MLA; PsycINFO Chiappe, P., Siegel, L. S., \& Gottardo, A. (2002). Reading-related skills of kindergartners from diverse linguistic backgrounds. Applied Psycholinguistics, 23(1), 95-116. doi:http://dx.doi.org/10.1017/S014271640200005X intervention study. International Journal of Bilingual Education and Bilingualism 19(5), 546-562. doi:http://dx.doi.org/10.1080/13670050.2015.1026873

PsycINFO

Tamis-LeMonda, C., Song, L., Luo, R., Kuchirko, Y., Kahana-Kalman, R., Yoshikawa, H., \& Raufman, J. (2014). Children's vocabulary growth in English and Spanish across early development and associations with school readiness skills. Developmental Neuropsychology, 39(2), 69-87.

doi:http://dx.doi.org/10.1080/87565641.2013.827198

PsycINFO
Jasińska, K., Kaja, K., \& Petitto, L. (2018). Age of bilingual exposure is related to the Jasińska et al., 2018 contribution of phonological and semantic knowledge to successful reading

\section{In-Text Citation

Statistics Assigned Study

Number

$\begin{array}{ll}\text { Hipfner-Boucher et } & \text { Pearson's, } \\ \text { al., 2014 } & \text { hierarchical } \\ & \text { multiple regression } \\ & \text { (for some variables) }\end{array}$

Yeong et al., $2014 \quad$ Pearson's,

hierarchical

multiple regression

Hsu et al., $2019 \quad$ Pearson's, path

analysis

Chiappe et al., 2002 Pearson's, stepwise multiple regression 
PRECURSORS OF BILINGUAL LITERACY DEVELOPMENT

medRxiv preprint doi: https:///doi.org/10.1101/2021.08.18.21262243; this version posted August 23, 2021. The copyright holder for this preprin
(which was not certified by peer review) is the authorffunder, who has granted medRxiv a license to display the preprint in perpetuity.

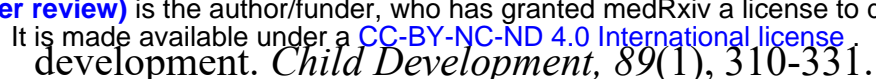

doi:http://dx.doi.org/10.1111/cdev.12745

PsycINFO

O'Brien, B. A., Mohamed, M. B. H., Yussof, N. T., \& Ng, S. C. (2019). The

O'Brien et al., 2019

Pearson's, multiple phonological awareness relation to early reading in English for three groups of simultaneous bilingual children. Reading and Writing: An Interdisciplinary Journal, regression, linear 32(4), 909-937. doi:http://dx.doi.org/10.1007/s11145-018-9890-1

regression

Language, Speech \& Hearing Services in Schools, 38(3), 237-48. Communication Disorders, 44(4), 444-458.

Oller, D. K., Pearson, B. Z., \& Cobo-lewis, A. (2007). Profile effects in early bilingual language and literacy. Applied Psycholinguistics, 28(2), 191. doi:http://dx.doi.org/10.1017/S0142716407070117

Bengochea, A., Justice, L. M., \& Hijlkema, M. J. (2017). Print knowledge in Yucatec Maya-Spanish bilingual children: An initial inquiry. International Journal of Bilingual Education and Bilingualism, 20(7), 807-822.

doi:http://dx.doi.org/10.1080/13670050.2015.1103699

PsycINFO

Cherodath, S., \& Singh, N. C. (2015). The influence of orthographic depth on reading networks in simultaneous biliterate children. Brain and Language, 143, 42-51. doi:http://dx.doi.org/10.1016/j.bandl.2015.02.001
Oller et al., 2007

Scheffe test/MANOVA

(effect size,

Cohen's d)

Bengochea et al., Pearson's 2017

Cherodath \& Singh, Repeated measures 2015 ANOVA orthographic transparency on typical and atypical reading development: Evidence in French-Spanish bilingual children. Research in Developmental Disabilities, 35(5),

1177-1190. doi:http://dx.doi.org/10.1016/j.ridd.2014.01.02 
PRECURSORS OF BILINGUAL LITERACY DEVELOPMENT

medRxiv preprint doi: https:///doi. org/10.1101/2021.08.18.21262243; this version posted August 23, 2021. The copyright holder for this preprin
(which was not certified by peer review) is the authorffunder, who has granted medRxiv a license to display the preprint in perpetuity.

It is made available under a CC-BY-NC-ND 4.0 International license.

Additional Search Bérubé, D., \& Marinova-Todd, S. (2012). The development of language and reading skills in the second and third languages of multilingual children in French immersion. International Journal of Multilingualism 9: 272-293.

Bérubé \&

Marinova-Todd

2012

Pearson's,

hierarchical

multiple regression

\section{D'angiulli et al., Pearson's}

and Italian in bilingual children. Applied Psycholinguistics, 22 (4): 479-507. doi:10.1017/S0142716401004015.

Additional Search

Ellis, N. C., \& Hooper, A. M. (2001). Why learning to read is easier in Welsh than in English: Orthographic transparency effects evinced with frequency-matched tests. Applied Psycholinguistics, 22, 571-599.

Additional Search

Jasińska, K. K., Wolf, S., Jukes, M. C., \& Dubeck, M. M. (2019). Literacy acquisition in multilingual educational contexts: Evidence from Coastal Kenya. Developmental Science, 128(28).

Additional Search

Kovelman, I., Salah-Ud-Din, M., Berens, M. S., \& Petitto, L. (2015). “One glove does not fit all" in bilingual reading acquisition: Using the age of first bilingual language exposure

to understand optimal contexts for reading success. Cogent Education, 2(1).

doi:10.1080/2331186X.2015.1006504

Additional Search

Lervåg, A., \& Aukrust, V. G. (2009). Vocabulary knowledge is a critical determinant of the difference in reading comprehension growth between first and second language learners." Journal of Child Psychology and Psychiatry, 51 (5): 612-620.

Additional Search

Spencer, L.H., \& Hanley, J.R. (2003), Effects of orthographic transparency on reading and phoneme awareness in children learning to read in Wales. British Journal of Psychology, 94: 1-28. doi:10.1348/000712603762842075

Additional Search

Lam, K., Chen, X., Geva, E., Luo, Y. C., \& Li, H. (2012). The role of morphologica awareness in reading achievement among young Chinese-speaking English language learners: A longitudinal study. Reading and Writing, 25(8), 1847-1872.

Additional Search

Limbird, C. K., Maluch, J. T., Rjosk, C., Stanat, P., \& Merkens, H. (2014). Differentia growth patterns in emerging reading skills of Turkish-German bilingual and German monolingual primary school students. Reading and Writing, 27(5), 945-968.
Ellis \& Hooper, Multiple regression regression 
PsycINFO

Rhys, M., \& Thomas, E. M. (2013). Bilingual Welsh-English children's acquisition of vocabulary and reading: Implications for bilingual education. International Journal of Bilingual Education and Bilingualism, 16(6), 633-656.

doi:http://dx.doi.org/10.1080/13670050.2012.706248

LLBA

Spatgens, T., \& Schoonen, R. (2018). The semantic network, lexical access, and reading comprehension in monolingual and bilingual children: An individual differences study. Applied Psycholinguistics, 39(1), 225-256.

doi:http://dx doi org/10.1017/S0142716417000224

Additional Search

Gupta, A., \& Jamal, G. (2007). Reading strategies of bilingual normally progressing and dyslexic readers in Hindi and English. Applied Psycholinguistics, 28(1), 47-68

Additional Search

Ríos-López, P., Molnar, M. T., Lizarazu, M., \& Lallier, M. (2017). The role of slow speech amplitude envelope for speech processing and reading development. Frontiers in Psychology, 8, 1497.

LLBA

Vital, H., \& Karniol, R. (2011). Procedural versus narrative cross-language priming and bilingual children's reading and sentence sequencing of same genre and opposite genre text in the other language. Bilingualism, 14(4), 547-561.

doi:http://dx.doi.org/10.1017/S1366728910000520

LLBA; PsycINFO

an den Bosch, L. J., Segers, E., \& Verhoeven, L. (2020). First and second language vocabulary affect early second language reading comprehension development. Journal of Research in Reading, 43(3), 290-308.

Additional Search Research Callou

Sun, H., Bornstein, M.H., \& Esposito, G. (2021). The specificity principle in young dual language learners' English development. Child

Development. https://doi.org/10.1111/cdev.13558
Rhys \&

Pearson's multiple regression

ANOVA/MANOV

A (effect size,

Cohen's d) 
PRECURSORS OF BILINGUAL LITERACY DEVELOPMENT

medRxiv preprint doi: hittps:///doi. org/10.1101/2021.08.18.21262243; this version posted August 23, 2021. The copyright holder for this preprint
(which was not certified by peer review) is the authorffunder, who has granted medxixi a license to display the preprint in perpetuity.

LLBA Mak, K.C.L. (2014). Reading comprehension in Chinese-English bilingual children: A

cognitive perspective. Masters Abstracts International 2014.

Pearson's,

33

hierarchical

multiple regression

Cohen's d (effect

size)

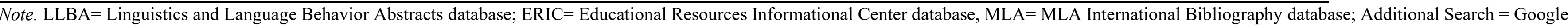
Scholar and manual citation search. 
PRECURSORS OF BILINGUAL LITERACY DEVELOPMENT

medRxiv preprint doi: https:///doi.org/10.1101/2021.08.18.21262243; this version posted August 23, 2021. The copyright holder for this preprint
(which was not certified by peer review) is the authorffunder, who has granted medRxiv a license to display the preprint in perpetuity.

Table 5

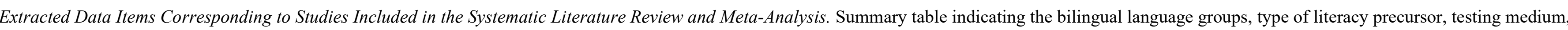
languages and measures of literacy precursor assessment, type of literacy outcome, languages and measures of literacy outcome assessment, mean age at assessment, sample size, and country of assessment corresponding to the 33 studies listed in Table 4.

\begin{tabular}{|c|c|c|c|c|c|c|c|c|c|}
\hline Study & $\begin{array}{c}\text { Bilingual } \\
\text { Language Group }\end{array}$ & $\begin{array}{l}\text { Literacy } \\
\text { Precursors }\end{array}$ & $\begin{array}{l}\text { Testing } \\
\text { Medium }\end{array}$ & $\begin{array}{c}\text { Languages and } \\
\text { Measures of Literacy } \\
\text { Precursor Assessment }\end{array}$ & $\begin{array}{l}\text { Literacy } \\
\text { Outcomes }\end{array}$ & $\begin{array}{c}\text { Languages and Measures } \\
\text { of Literacy Outcome } \\
\text { Assessment }\end{array}$ & $\begin{array}{l}\text { Mean } \\
\text { Age } \\
\text { (in } \\
\text { years) }\end{array}$ & $\mathrm{n}$ & $\begin{array}{l}\text { Country of } \\
\text { Assessment }\end{array}$ \\
\hline \multirow[t]{3}{*}{1} & Chinese-English & $\begin{array}{l}\text { Phonological } \\
\text { Awareness }\end{array}$ & Within; Across & $\begin{array}{l}\text { Chinese (phoneme and } \\
\text { syllable deletion); } \\
\text { English } \\
\text { (Comprehensive Test of } \\
\text { Phonological } \\
\text { Processing; CTOPP; } \\
\text { phoneme and syllable } \\
\text { deletion) }\end{array}$ & $\begin{array}{l}\text { Word Reading } \\
\text { Accuracy }\end{array}$ & $\begin{array}{c}\text { English (Letter-Word } \\
\text { Identification subtest, } \\
\text { Woodcock Language } \\
\text { Proficiency Battery; } \\
\text { WLPB) }\end{array}$ & & & Canada \\
\hline & & $\begin{array}{l}\text { Receptive } \\
\text { Vocabulary }\end{array}$ & Within & $\begin{array}{l}\text { English (Peabody } \\
\text { Picture Vocabulary } \\
\text { Test; PPVT) }\end{array}$ & $\begin{array}{l}\text { Word Reading } \\
\text { Accuracy }\end{array}$ & $\begin{array}{l}\text { English (Letter-Word } \\
\text { Identification subtest; } \\
\text { WLPB) }\end{array}$ & & & \\
\hline & & $\begin{array}{l}\text { Morphological } \\
\text { Awareness }\end{array}$ & Within & $\begin{array}{l}\text { English (Compound } \\
\text { word awareness) }\end{array}$ & $\begin{array}{l}\text { Word Reading } \\
\text { Accuracy }\end{array}$ & $\begin{array}{l}\text { English (Letter-Word } \\
\text { Identification subtest; } \\
\text { WLPB) }\end{array}$ & & & \\
\hline $1 A$ & $\begin{array}{c}\text { Bilingual } \\
\text { Chinese-English }\end{array}$ & & & & & & 6.10 & 20 & \\
\hline $1 B$ & $\begin{array}{l}\text { English-only } \\
\text { schooling }\end{array}$ & & & & & & 6.07 & 33 & \\
\hline \multirow[t]{2}{*}{2} & Chinese-English & $\begin{array}{l}\text { Phonological } \\
\text { Awareness }\end{array}$ & Within & $\begin{array}{l}\text { English (CTOPP: Silent } \\
\text { Phonological Choice } \\
\text { Task); phoneme and } \\
\text { syllable blending; } \\
\text { phonological recording }\end{array}$ & $\begin{array}{l}\text { Word Reading } \\
\text { Accuracy }\end{array}$ & $\begin{array}{c}\text { English (Wechsler } \\
\text { Individual Achievement } \\
\text { Test 2: Australian } \\
\text { Adaptation; WIAT) }\end{array}$ & & & Singapore \\
\hline & & $\begin{array}{l}\text { Orthographic } \\
\text { Processing } \\
\text { Skills }\end{array}$ & Within & $\begin{array}{l}\text { English (orthographic } \\
\text { choice task; } \\
\text { homophone verification } \\
\text { task; non-lexical choice } \\
\text { task) }\end{array}$ & $\begin{array}{l}\text { Word Reading } \\
\text { Accuracy }\end{array}$ & English (WIAT) & & & \\
\hline $2 A$ & $\begin{array}{c}\text { Grade 2-3 English } \\
\text { L1 }\end{array}$ & & & & & & 8.02 & 29 & \\
\hline $2 B$ & $\begin{array}{l}\text { Grade 2-3 } \\
\text { Mandarin L1 }\end{array}$ & & & & & & 8.02 & 27 & \\
\hline $2 C$ & $\begin{array}{l}\text { Grade 5-6 English } \\
\text { L1 }\end{array}$ & & & & & & 11 & 25 & \\
\hline $2 D$ & $\begin{array}{c}\text { Grade 5-6 } \\
\text { Mandarin L1 }\end{array}$ & & & & & & 11 & 25 & \\
\hline
\end{tabular}


PRECURSORS OF BILINGUAL LITERACY DEVELOPMENT

medRxiv preprint doi: https:///doi. org/10.1101/2021.08. 18.21262243; this version posted August 23, 2021. The copyright holder for this preprin
(which was not certified by peer review) is the authorffunder, who has granted medRxiv a license to display the preprint in perpetuity.

3 Chinese-English avaliable under a C C.-BY-NC-ND.4.0 International license.

Receptive Within; Across

Vocabulary

Morphological Within; Across
Awareness

4

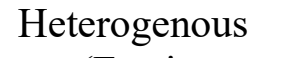

Phonological

Within

$$
\text { (Farsi, }
$$

Japanese, Spanish

, Tagalog,

Chinese, French,

Slovakian,

Arabic, German,

Greek, Hindi or

Indoek, Hindi or

English

Verbal Short-

Term Memory

Syntactic

Awareness

Letter

Knowledge

Serial Recal

Spelling

Environmental

Print

Awareness

Malay-English Morphological Within; Across Awareness

Word Reading

\section{syllable deletion);}

Word Reading

English (CTOPP;

phoneme and syllable

$$
\text { deletion) }
$$

Chinese (Cantonese

Receptive Vocabulary

Test; CRVT); English

vocabulary subtes

Kaufman Brief

Intelligence Test,

Second Edition; KBIT-

$$
\text { 2) }
$$

(Morphologica

udgement Task);
English (Test of

Morphological Structure)

Accuracy

Chinese (Character

$8.07 \quad 57$

US

recognition test); English

(Word Identification subset

of the Woodcock Reading

Mastery Tests - Revised;

WRMT-R)

Word Reading Chinese (Character

recognition test); English

(Word Identification subset;

WRMT-R)

Word Reading

Accuracy

Chinese (Character

recognition test); English

(Word Identification subset;

WRMT-R)

Word Reading

English (sound

mimicry, rhyme

detection, syllable and

phoneme identification,

and phoneme deletion)

English (Memory for

Sentences subtest of the

Stanford Binet Test)

English (oral cloze

$$
\text { task) }
$$

English (letter

identification task)

English (rapid picture aming)

Accuracy

English (letter-word reading

subtest of the Wide Range

Achievement Test-3

$$
\text { WRAT-3) }
$$

English (letter-word reading subtest; WRAT-3)

Word Reading

Accuracy

Word Reading

Accuracy

Word Reading

Accuracy

English (word spelling)

Word Reading

$$
\text { Accuracy }
$$

English (naming of common English logos)

Word Reading

Accuracy

English (letter-word reading subtest; WRAT-3)

English (letter-word reading subtest; WRAT-3)

English (letter-word reading subtest; WRAT-3)

English (letter-word reading subtest; WRAT-3)

English (letter-word reading subtest; WRAT-3)

Word Reading Accuracy; Word Reading Speed
English; Malay
$5.04 \quad 59 \quad$ Canada

Singapore 
PRECURSORS OF BILINGUAL LITERACY DEVELOPMENT

medRxiv preprint doi: https:///doi.org/10.1101/2021.08.18.221262243; this version posted August 23, 2021. The copyright holder for this preprint
(which was not certified by peer review) is the authorffunder, who has granted medR xiv a license to display the preprint in perpetutity.

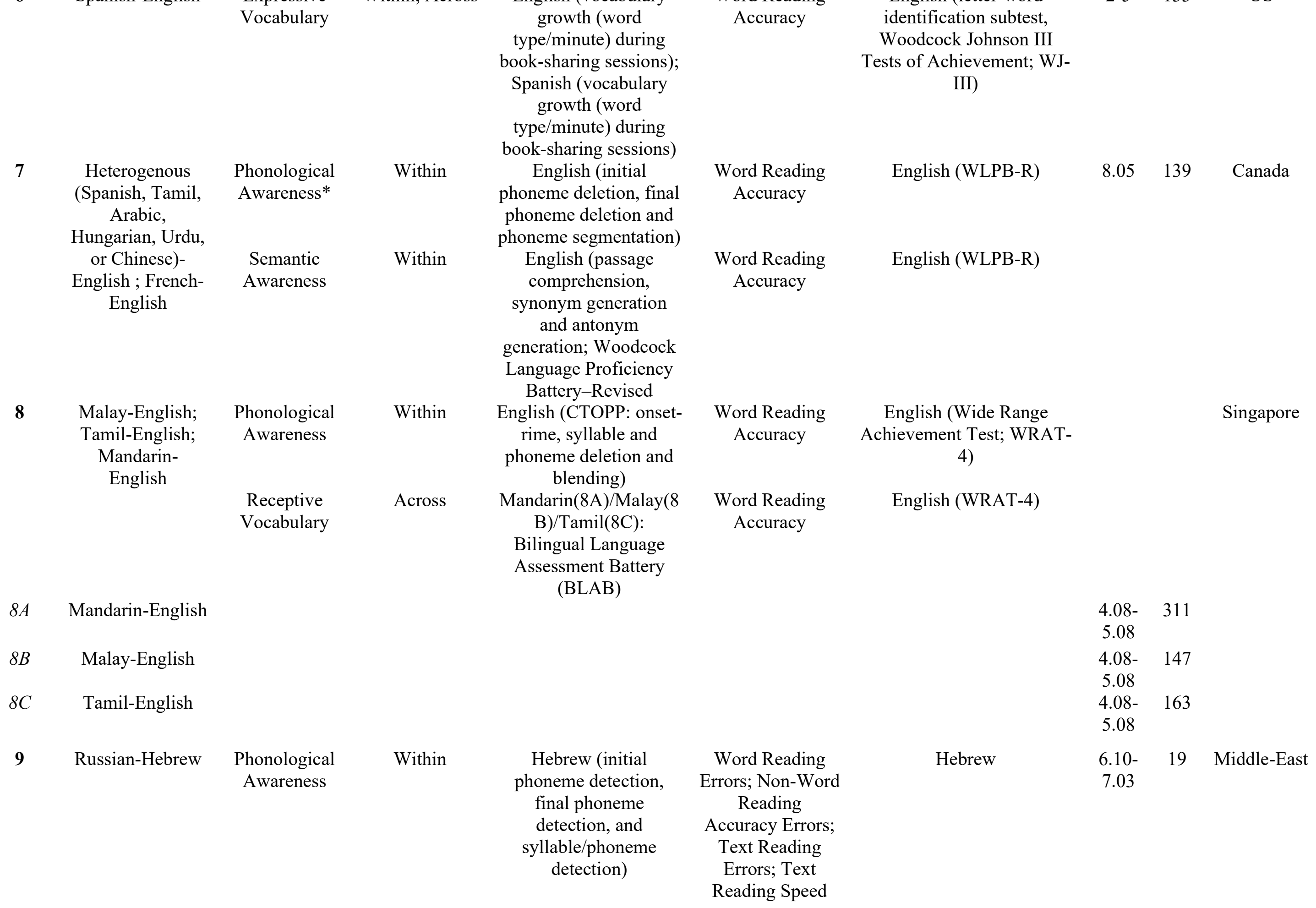


PRECURSORS OF BILINGUAL LITERACY DEVELOPMENT

medRxiv preprint doi: https:///doi. org/10.1101/2021.08.18.21262243; this version posted August 23, 2021. The copyright holder for this preprint
(which was not certified by peer review is the authorffunder, who has granted medRxiv a license to display the preprint in perpetuity.

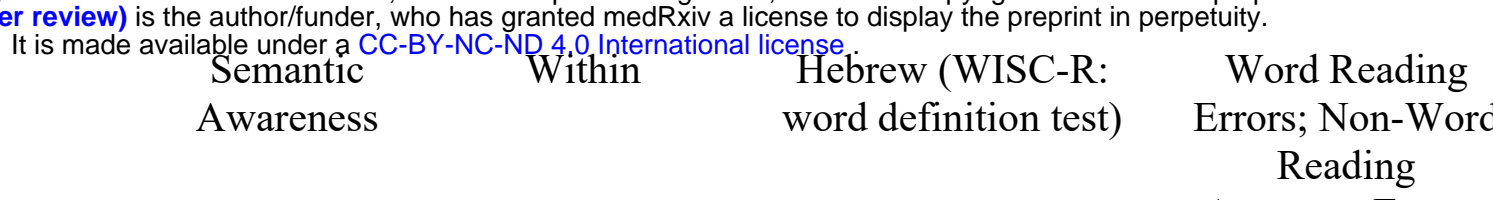

Reading

Accuracy Errors
Text Reading

Errors; Text

Reading Speed

10 Spanish-English

\section{Receptive \\ and Oral \\ Language}

Comprehensio

Within; Across

Spanish(Test de
vocabulario en

ima'genes Peabody;

TVIP and Preschool

Language Scale-3

PLS-3); English

(PPVT-III and Test of

Early Language

Development- 3;

TELD-3)

11 Spanish-English

Receptive Within; Across

Vocabulary

Spanish (TVIP);

English (PPVT-III)

Oral Language Within; Across

Spanish (receptive

language subtestPLS

3); English (auditory comprehension subtest

$$
\text { TELD-3) }
$$

\section{Word Reading Accuracy; Text}

Reading

Comprehension

Word Reading Accuracy; Text Reading Comprehension
Spanish (letter-word identification and passage comprehension subtests; WLPB-R); English (letterword identification and passage comprehension subtests; WLPB-R) Spanish (letter-word identification and passage comprehension subtests; WLPB-R); English (letterword identification and passage comprehension subtests; WLPB-R)

\begin{tabular}{|c|c|c|c|}
\hline Spanish-English & $\begin{array}{l}\text { Type of } \\
\text { Literacy } \\
\text { Outcome } \\
\text { Measure }\end{array}$ & Within & $\begin{array}{l}\text { Spanish (Woodcock- } \\
\text { Johnson and } \\
\text { Woodcock-Munoz } \\
\text { language and literacy } \\
\text { evaluations); English } \\
\text { (Woodcock-Johnson } \\
\text { and Woodcock-Munoz } \\
\text { language and literacy }\end{array}$ \\
\hline
\end{tabular}

$$
\text { evaluations) }
$$


PRECURSORS OF BILINGUAL LITERACY DEVELOPMENT

medRxiv preprint doi: https:///doi. org/10.1101/2021.08. 18.21262243; this version posted August 23, 2021. The copyright holder for this preprin
(which was not certified by peer review) is the authorffunder, who has granted medRxiv a license to display the preprint in perpetuity.

$124 \quad$ Grade $2^{\text {Is }}$ made available under a CC-BY-NC-ND 4.0 International license.

$12 B \quad$ Grade 5

Grade 704

Grade 704

$13 \quad$ Maya-Spanish

$$
\begin{aligned}
& \text { Letter } \\
& \text { Knowledge }
\end{aligned}
$$

Within; Across

Spanish (Phonological Awareness Literacy Screening-PreK;

Name Writing

Across

Spanish; Maya

Word Reading Accuracy

Word Reading Accuracy

Hindi; English

Awareness

(Neural Study)

15

Spanish-French

Phonological
Awareness*

Within

Spanish (initial

phoneme deletion and acronym task); French (initial phoneme deletion and acronym task)

VA Span

Within

Spanish and French (whole report task and partial report task)

Accuracy; Word

Reading Speed

Non-Word

Reading

Word Reading

Speed; Text

Reading Errors;

Text Reading

$$
\text { Speed }
$$
Alphabetic
(Africans,
Amharic,
Croatian, Czech,
Danish, Fanti,

Receptive

German, Greek
Within

English (PPVT-III)

Word Reading

Accuracy; Non-

Word Reading

Accuracy; Text

Reading

Comprehension
English (Woodcock

Language Battery

Proficiency; WLPB-R)
$4.10 \quad 84$

Spain

Spanish; Maya

Hindi; English

$9.21 \quad 44$

India

Spain

Canada 
PRECURSORS OF BILINGUAL LITERACY DEVELOPMENT

medRxiv preprint doi: https:///doi.org/10.1101/2021.08. 18.21262243; this version posted August 23, 2021. The copyright holder for this preprin
(which was not certified by peer review) is the authorffunder, who has granted medRxiv a license to display the preprint in perpetuity.

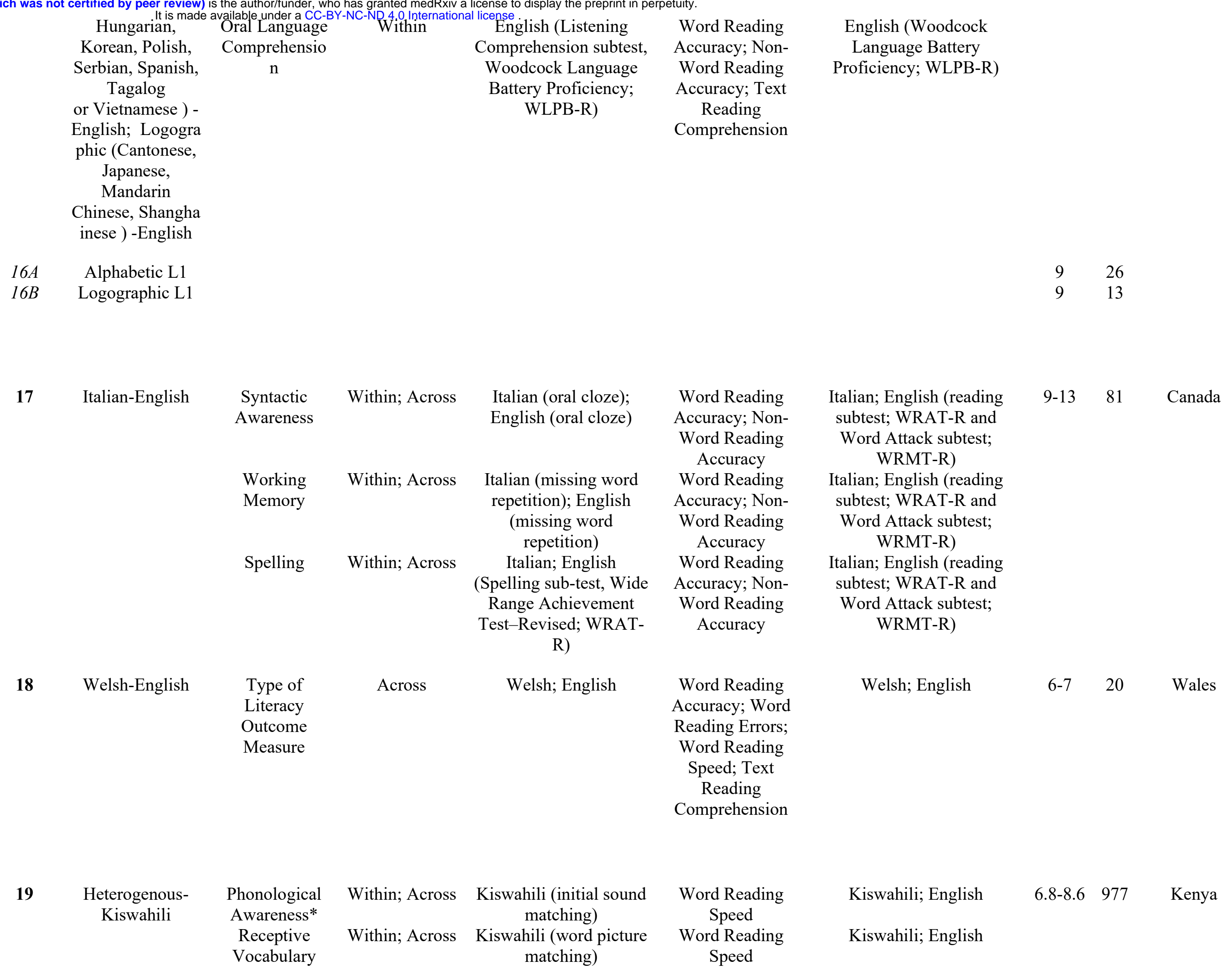


PRECURSORS OF BILINGUAL LITERACY DEVELOPMENT

medRxiv preprint doi: https:///doi. org/10.1101/2021.08. 18.21262243; this version posted August 23, 2021. The copyright holder for this preprin
(which was not certified by peer review) is the authorffunder, who has granted medRxiv a license to display the preprint in perpetuity.

\begin{tabular}{|c|c|c|c|c|c|c|c|c|c|}
\hline 20 & $\begin{array}{l}\text { Spanish-English } \\
\text { Sphe }\end{array}$ & $\begin{array}{l}\text { ailable under af CC-E } \\
\text { Type of } \\
\text { Reading } \\
\text { Instruction }\end{array}$ & $\begin{array}{l}\text { CC-NQ 4. Onternatic } \\
\text { Within }\end{array}$ & $\begin{array}{l}\text { al license } \\
\text { Spanish; English } \\
\text { (Phonics Reading } \\
\text { Instruction; Success for } \\
\text { All; SFA and Whole } \\
\text { Language Reading } \\
\text { Instruction) }\end{array}$ & $\begin{array}{c}\text { Word Reading } \\
\text { Accuracy; Non- } \\
\text { Word Reading } \\
\text { Accuracy; Text } \\
\text { Reading } \\
\text { Comprehension }\end{array}$ & Spanish; English & $7-9$ & 23 & US \\
\hline & Urdu-Norwegian & $\begin{array}{c}\text { Word } \\
\text { Decoding }\end{array}$ & Within & $\begin{array}{l}\text { Norwegian (Test of } \\
\text { Word Reading } \\
\text { Efficiency; TOWRE) }\end{array}$ & $\begin{array}{l}\text { Text Reading } \\
\text { Comprehension }\end{array}$ & $\begin{array}{l}\text { Norwegian (passage } \\
\text { comprehension subtest; } \\
\text { WRMT-PC and NARA II) }\end{array}$ & & & \\
\hline & & $\begin{array}{l}\text { Receptive } \\
\text { Vocabulary }\end{array}$ & Within; Across & $\begin{array}{l}\text { Welsh (British Picture } \\
\text { Vocabulary Scale; } \\
\text { BPVS) }\end{array}$ & $\begin{array}{l}\text { Word Reading } \\
\text { Accuracy }\end{array}$ & Welsh; English & & & \\
\hline & & Serial Recall & Within; Across & $\begin{array}{l}\text { Welsh and English } \\
\text { (Digit span test, WISC- } \\
\text { R) }\end{array}$ & $\begin{array}{l}\text { Word Reading } \\
\text { Accuracy }\end{array}$ & Welsh; English & & & \\
\hline & & $\begin{array}{l}\text { Non-Verbal } \\
\text { Intelligence }\end{array}$ & Within; Across & $\begin{array}{c}\text { Welsh and English } \\
\text { (Raven's Coloured } \\
\text { Progressive Matrices; } \\
\text { CPM) }\end{array}$ & $\begin{array}{l}\text { Word Reading } \\
\text { Accuracy }\end{array}$ & Welsh; English & & & \\
\hline 23 & Chinese-English & $\begin{array}{l}\text { Phonological } \\
\text { Awareness* }\end{array}$ & Within & $\begin{array}{l}\text { English (CTOPP-2: } \\
\text { phoneme deletion) }\end{array}$ & $\begin{array}{l}\text { Word Reading } \\
\text { Accuracy; Text } \\
\text { Reading } \\
\text { Comprehension }\end{array}$ & $\begin{array}{c}\text { English (Reading } \\
\text { Comprehension subtest, } \\
\text { Peabody Individual } \\
\text { Achievement Test-- } \\
\text { Revised; PIAT-R) }\end{array}$ & & & Canada \\
\hline
\end{tabular}


PRECURSORS OF BILINGUAL LITERACY DEVELOPMENT

medRxiv preprint doi: https:///doi.org/10.1101/2021.08. 18.21262243; this version posted August 23, 2021. The copyright holder for this preprin
(which was not certified by peer review) is the authorffunder, who has granted medRxiv a license to display the preprint in perpetuity.

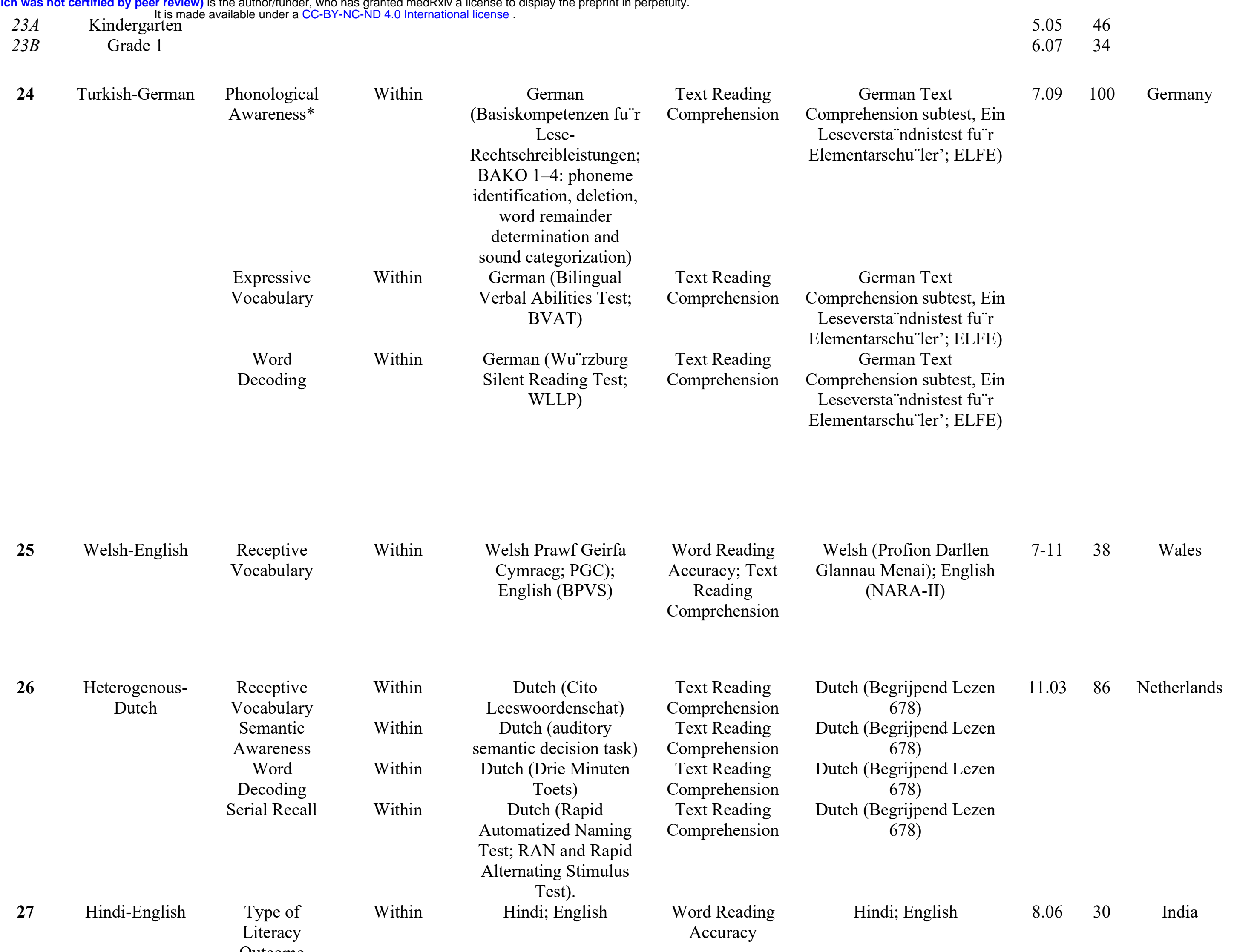


PRECURSORS OF BILINGUAL LITERACY DEVELOPMENT

medRxiv preprint doi: https:///doi. org/10.1101/2021.08. 18.21262243; this version posted August 23, 2021. The copyright holder for this preprin
(which was not certified by peer review) is the authorffunder, who has granted medRxiv a license to display the preprint in perpetuity.

\begin{tabular}{|c|c|c|c|c|c|c|c|c|c|}
\hline 28 & $\begin{array}{l}\text { Basque-Spanishade } \\
\text { Bish is }\end{array}$ & $\begin{array}{l}\text { ailable under a CC-E } \\
\text { Speech } \\
\text { Perception }\end{array}$ & $\begin{array}{l}\text {-NC-NQ4.0 Internation } \\
\text { Within }\end{array}$ & Spanish & $\begin{array}{c}\text { Word Reading } \\
\text { Accuracy; Word } \\
\text { Reading Errors; } \\
\text { Non-Word } \\
\text { Reading } \\
\text { Accuracy; Non- } \\
\text { Word Reading } \\
\text { Errors; Text } \\
\text { Reading Errors; } \\
\text { Text Reading } \\
\text { Speed }\end{array}$ & $\begin{array}{l}\text { Spanish (El principito and } \\
\text { PROLEC-R) }\end{array}$ & & 20 & Spain \\
\hline $28 A$ & Grade 2 & & & & & & 7.07 & & \\
\hline $28 B$ & Grade 5 & & & & & & 11 & & \\
\hline 29 & Hebrew-English & $\begin{array}{l}\text { Sentence } \\
\text { Priming }\end{array}$ & Across & English & $\begin{array}{l}\text { Text Reading } \\
\text { Errors; Text } \\
\text { Reading Speed; } \\
\text { Text Reading } \\
\text { Comprehension }\end{array}$ & Hebrew & $\begin{array}{l}\text { Grades } \\
5-6\end{array}$ & 101 & Middle-East \\
\hline 31 & Chinese-English & $\begin{array}{l}\text { Working } \\
\text { Memory } \\
\text { Non-Verbal } \\
\text { Intelligence }\end{array}$ & $\begin{array}{l}\text { Within } \\
\text { Within }\end{array}$ & $\begin{array}{c}\text { English (Backward } \\
\text { Digit Recall) } \\
\text { English (Raven's CPM) }\end{array}$ & $\begin{array}{l}\text { Word Reading } \\
\text { Accuracy } \\
\text { Word Reading } \\
\text { Accuracy }\end{array}$ & $\begin{array}{l}\text { English (Word Reading } \\
\text { Subtest; WRAT) } \\
\text { English (Word Reading } \\
\text { Subtest; WRAT) }\end{array}$ & $\begin{array}{l}4.01- \\
5.05\end{array}$ & 736 & Singapore \\
\hline
\end{tabular}


PRECURSORS OF BILINGUAL LITERACY DEVELOPMENT

medRxiv preprint doi: https:///doi.org/10.1101/2021.08. 18.21262243; this version posted August 23, 2021. The copyright holder for this preprin
(which was not certified by peer review) is the authorffunder, who has granted medRxiv a license to display the preprint in perpetuity.

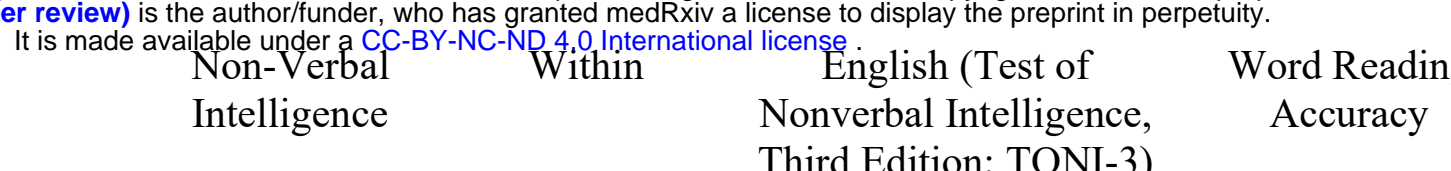

33

Chinese-English

Phonological

Awareness

Within; Across

Nonverbal

Accuracy

Word Reading Accuracy; Non-

Word Reading

Accuracy; Tex

Reading

Cnd syllable dele

English (CTOPP

phoneme deletion)

Comprehension

Serial Recall

Within; Across

Chinese (Forward Digit

Span subtest, Wechsler

Intelligence Scale for

Children - Third

Edition; WISC-III) and

English (Forward Digit

Span subtest; WISC-III)

Receptive

Within; Across

Chinese (PPVT-III); English (PPVT-III)

Vocabulary

Expressive

Vocabulary

Within; Across

Chinese (Expressive

One-Word Picture

ocabulary Test - Third

edition; EOWPVT-III);

English

( EOWPVT-III)

Non-Verbal

Intelligence
Within; Across Chinese and English

(Matrix Analogies Test)
Word Reading

Accuracy; Non-

Word Reading

Accuracy; Text

Reading

Comprehension

Word Reading

Accuracy; Non-

Word Reading

Accuracy; Text

Reading

Comprehension

Word Reading

Accuracy; Non-

Word Reading

Accuracy; Text

Reading

Comprehension

Word Reading

y; Non-

Word Reading

Accuracy; Text
Reading

Comprehension
English (Word

Identification Subtest WRAT-R)

Chinese (Character Recognition Test, Pseudo-

Character Test and Gray

Oral Reading Test Forth

Edition; GORT-4); English

(Word Identification

Subtest, WRMT-R, Word

Attack Subtest; WRMT-R

$$
\text { and NARA) }
$$

Chinese (Character

Recognition Test, Pseudo-

Character Test and Gray

Oral Reading Test Forth

Edition; GORT-4); English

(Word Identification

Subtest, WRMT-R, Word

Attack Subtest; WRMT-R

$$
\text { and NARA) }
$$

Chinese (Character

Recognition Test, PseudoCharacter Test and Gray Oral Reading Test Forth

Edition; GORT-4); English

(Word Identification

Subtest, WRMT-R, Word and NARA)

Chinese (Character Recognition Test, PseudoCharacter Test and Gray

Oral Reading Test Forth Edition; GORT-4); English (Word Identification Subtest, WRMT-R, Word Attack Subtest; WRMT-R and NARA)

Chinese (Character Recognition Test, PseudoCharacter Test and Gray Oral Reading Test Forth Edition; GORT-4); English (Word Identification 
Subtest, WRMT-R, Word Attack Subtest; WRMT-R and NARA)

$\begin{array}{ccc}\begin{array}{c}\text { Word } \\ \text { Decoding }\end{array} & \text { Within; Across } & \text { Chinese (Chinese } \\ \text { Character Recognition } \\ \text { test); English (word } \\ \text { identification subtest; } \\ \text { WRMT-R) }\end{array}$

Non-Word Decoding

\begin{abstract}
Verbal
Working
\end{abstract}

Memory/Seria

Recall

Within; Across

Task); English
(Backward Digit Span
subtest; WISC-III and
Verbal Working
Memory Task)

Non-Verbal Within; Across Chinese and English Working Memory

Syntactic Within; Across

(Swanson's Visual Matrix subtest, Test of Working Memory)

Awareness

$$
\text { Working }
$$

Chinese (Chinese Syntactic Awareness
Word Reading Accuracy; NonWord Reading Accuracy; Text

$$
\text { Reading }
$$

Comprehension

$$
\begin{aligned}
& \text { Chinese (Chinese } \\
& \text { Pseudo-Character Test); } \\
& \text { English (word attack } \\
& \text { subtest; WRMT-R) }
\end{aligned}
$$

Chinese (Backward Digit Span subtest; WISC-III and Verbal Task); English ard Digit Span Verbal Working Task); English (Syntactic Judgment task)

Word Reading Accuracy; NonWord Reading Accuracy; Text Reading

Comprehension

Word Reading Accuracy; NonWord Reading Accuracy; Text

Reading

Comprehension

Word Reading Accuracy; NonWord Reading Accuracy; Text

$$
\text { Reading }
$$

Comprehension

Word Reading Accuracy; NonWord Reading Accuracy; Text Reading

\section{Chinese (Character}

Recognition Test, Pseudo-

Character Test and Gray

Oral Reading Test Forth

Edition; GORT-4); English (Word Identification Subtest, WRMT-R, Word Attack Subtest; WRMT-R and NARA)

Chinese (Character Recognition Test, PseudoCharacter Test and Gray Oral Reading Test Forth Edition; GORT-4); English (Word Identification Subtest, WRMT-R, Word Attack Subtest; WRMT-R

$$
\text { and NARA) }
$$

Chinese (Character

Recognition Test, PseudoCharacter Test and Gray Oral Reading Test Forth Edition; GORT-4); English (Word Identification Subtest, WRMT-R, Word Attack Subtest; WRMT-R and NARA)

Chinese (Character Recognition Test, PseudoCharacter Test and Gray Oral Reading Test Forth Edition; GORT-4); English (Word Identification Subtest, WRMT-R, Word Attack Subtest; WRMT-R

Chinese (Character Recognition Test, PseudoCharacter Test and Gray Oral Reading Test Forth Edition; GORT-4); English Comprehension 
PRECURSORS OF BILINGUAL LITERACY DEVELOPMENT

medRxiv preprint doi: https:///doi.org/10.1101/2021.08. 18.21262243; this version posted August 23, 2021. The copyright holder for this preprin
(which was not certified by peer review) is the authorffunder, who has granted medRxiv a license to display the preprint in perpetuity.

It is made available under a CC-BY-NC-ND 4.0 International license.

Subtest, WRMT-R, Word

Attack Subtest; WRMT-R and NARA)

\begin{tabular}{|c|c|c|c|c|}
\hline $\begin{array}{c}\text { Morphological } \\
\text { Awareness }\end{array}$ & Within; Across & $\begin{array}{l}\text { Chinese (Chinese } \\
\text { Derivational and } \\
\text { Compound Morpheme } \\
\text { Awareness Test); } \\
\text { English (Test of } \\
\text { Morphological } \\
\text { Structure) }\end{array}$ & $\begin{array}{l}\text { Word Reading } \\
\text { Accuracy; Non- } \\
\text { Word Reading } \\
\text { Accuracy; Text } \\
\text { Reading } \\
\text { Comprehension }\end{array}$ & $\begin{array}{c}\text { Chinese (Character } \\
\text { Recognition Test, Pseudo- } \\
\text { Character Test and Gray } \\
\text { Oral Reading Test Forth } \\
\text { Edition; GORT-4); English } \\
\text { (Word Identification } \\
\text { Subtest, WRMT-R, Word } \\
\text { Attack Subtest; WRMT-R } \\
\text { and NARA) }\end{array}$ \\
\hline
\end{tabular}

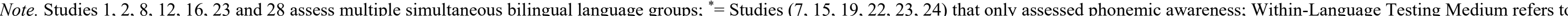
literacy precursors and outcome measures assessed in the same language; Across-Language Testing Medium refers to literacy precursors and outcome measures assessed in different languages. 
PRECURSORS OF BILINGUAL LITERACY DEVELOPMENT

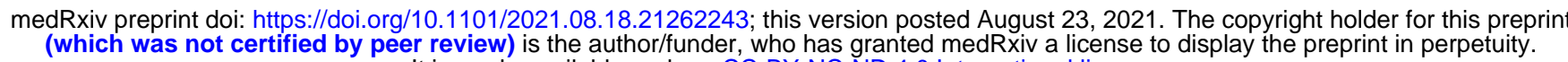

Table 6

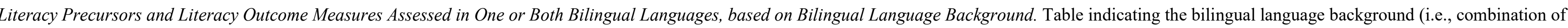

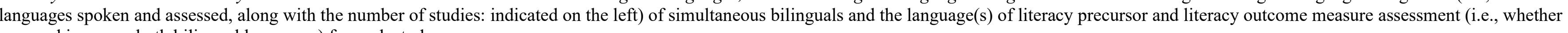
assessed in one or both bilingual languages) for each study.

\begin{tabular}{|c|c|c|c|c|}
\hline $\begin{array}{l}\text { Type of Bilinguals ( } n=\text { number } \\
\text { of studies): }\end{array}$ & $\begin{array}{l}\text { Literacy Precursors and Outcomes Assessed in } \\
\text { Both Bilingual Languages }\end{array}$ & $\begin{array}{l}\text { Literacy Precursors and Outcomes Assessed in } 1 \\
\text { Bilingual Language }\end{array}$ & $\begin{array}{l}\text { Literacy Precursors Assessed in Both } \\
\text { Bilingual Languages and Outcomes } \\
\text { Assessed in } 1 \text { Bilingual Language }\end{array}$ & $\begin{array}{l}\text { Literacy Precursors Assessed in } 1 \\
\text { Bilingual Language and Outcomes } \\
\text { Assessed in Both Bilingual Languages }\end{array}$ \\
\hline & 14 studies & 13 studies & 6 studies & 1 study \\
\hline Heterogenous-English $(n=4)$ & 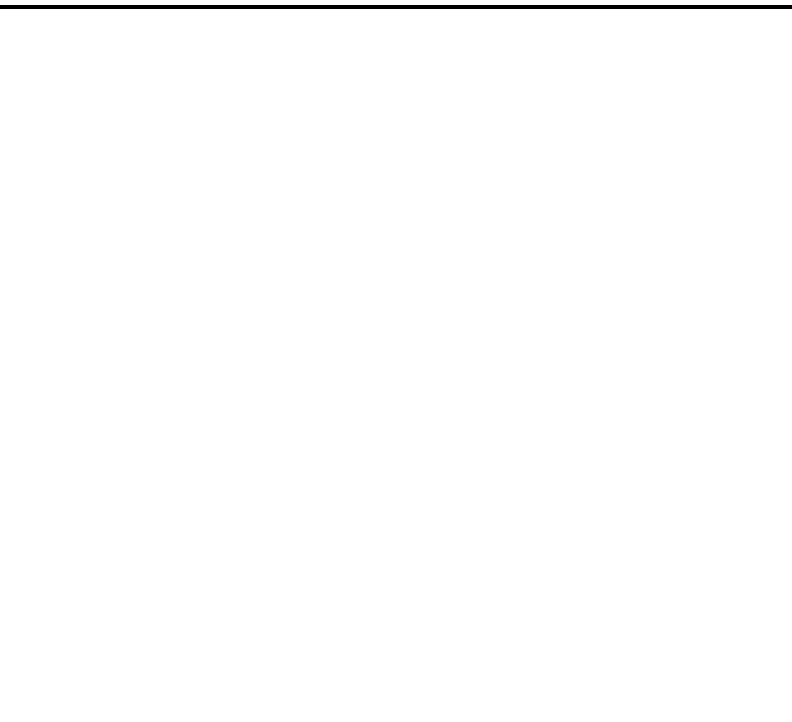 & $\begin{array}{l}\text { 4*(Farsi, Japanese, Spanish, Tagalog, Chinese, French, } \\
\text { Slovakian, Squamish, Arabic, German, Greek, Hindi or } \\
\text { Indonesian) - English } \\
\text { PL \& OL (English); } \\
\text { 7*(Spanish, Tamil, Arabic, Hungarian, Urdu } \\
\text { or Chinese) - English } \\
\text { PL \& OL (English); } \\
\text { 16*Alphabetic (Africans, Amharic, Croatian, Czech, Danish, } \\
\text { Fanti, German, Greek, Hungarian, Korean, Polish, Serbian, } \\
\text { Spanish, Tagalog or Vietnamese ) - English } \\
\text { or Logographic (Cantonese, Japanese, Mandarin Chinese, } \\
\text { Shanghainese ) language -English } \\
\text { PL \& oL (English) }\end{array}$ & $\begin{array}{l}8^{*}(\text { Malay, Tamil or Mandarin-Chinese })+\text { English } \\
{ }^{{ }^{2}} \text { (Malay, Tamil or Mandarin-Chinese and English) } \\
\mathrm{OL}_{\text {(English })}\end{array}$ & \\
\hline Spanish-English $(n=5)$ & $\begin{array}{l}10^{\text {PL \& OL (Spanish and English); }} \\
11^{\text {PL \& OL (Spanish and English); }} \\
12^{\text {PL \& OL (Spanish and English); }} \\
20^{\text {PL \& oL (Spanish and English) }}\end{array}$ & & $\begin{array}{l}\text { 6 }^{\mathrm{PL}} \text { (Spanish and English) } \\
\text { oL (English) }\end{array}$ & \\
\hline $\begin{array}{l}\text { Mandarin (Chinese)-English } \\
(n=7)\end{array}$ & $\begin{array}{l}3 \text { PL \& OL (Chinese and English) } \\
33^{\text {PL \& oL (Chinese and English) }}\end{array}$ & $\begin{array}{l}2^{\text {PL \& OL }} \text { (English); } \\
23^{\text {PL \& OL }} \text { (English); } \\
3^{\text {PL \& OL }} \text { (English) }\end{array}$ & $\begin{array}{l}1^{\text {PL }} \text { (Chinese and English) } \\
\text { oL (English); } \\
32^{\text {PL }(\text { Chinese and English) }} \\
\text { oL (English) }\end{array}$ & \\
\hline
\end{tabular}


PRECURSORS OF BILINGUAL LITERACY DEVELOPMENT

medRxiv preprint doi: https:///doi.org/10.1101/2021.08. 18.21262243; this version posted August 23, 2021. The copyright holder for this preprint
(which was not certified by peer review) is the authorffunder, who has granted medRxiv a license to display the preprint in perpetuity.

Hindi-English ( $n=2)$

$27^{\text {PL \& OL }}$ (Hindi and English)

Welsh-English ( $n=3$ )

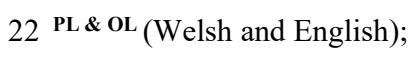

$18^{\mathrm{PL} \& \mathrm{OL}}$ (Welsh)

$25^{\text {PL \& OL }}$ (Welsh and English)

Malay-English $(n=1)$

$5^{\mathrm{PL}}$ (English)

oL (Malay and English)

Italian-English ( $n=1)$

$17^{\text {PL \& OL (Italian and English) }}$

Hebrew-English (n=1)

$29^{\text {PL \& OL (Hebrew) }}$

French-English (n=1)

7 PL \& OL (French and English)

Heterogenous-Dutch $(n=1)$

$26^{\mathrm{PL} \& \text { oL }}$ (Dutch)

Heterogeneous-Kiswahili $(n=1)$

19 PL \& OL (Kiswahili)

Russian-Hebrew ( $n=1)$

$9^{\text {PL \& OL (Hebrew) }}$

Spanish-French (n=1)

$15^{\text {PL \& OL (Spanish and French) }}$

Basque-Spanish (n=1)

$28^{\text {PL \& OL }}$ (Spanish)

Maya-Spanish (n=1)

13 PL \& OL (Maya and Spanish)

Turkish-German ( $n=1)$

$24^{\text {PL \& OL }}$ (German)

Turkish-Dutch ( $n=1)$

Urdu-Norwegian $(n=1)$

$30^{\text {PL (Turkish and Dutch) }}$

oL (Dutch)

$21^{\text {PL }}$ (Norwegian and Urdu)

oL (Norwegian)

Note. ${ }^{*}=$ specifies type of Heterogenous-English simultaneous bilingual language background; ${ }^{\mathrm{PL}}=\left(\right.$ precursor language) indicates language(s) assessed for literacy precursor measures; ${ }^{\mathrm{OL}}=($ outcome language $)$ indicates language(s) assessed for literacy outcome measures. 
PRECURSORS OF BILINGUAL LITERACY DEVELOPMENT

medRxiv preprint doi: httrss://doi. org/10.1101/2021.08.18.21262243; this version posted August 23, 2021. The copyright holder for this preprint
(which was not certified by peer review) is the authorffunder, who has granted medRxiv a license to display the preprint in perpetuity.

Table 7

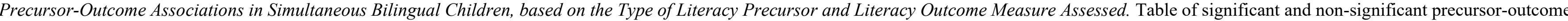

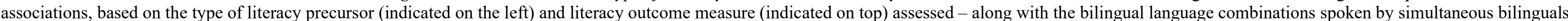
in each study (as denoted by *). Table 7 indicates significant and non-significant associations between given literacy precursors (indicated on the left) and given literacy outcome measures (indicated on top), as reported by the individual studies listed in Table 4.

Word Reading Accuracy

Word Reading Speed
Non-Word Reading Accuracy

Significant
Significant Not
Significant
Not Significant

Not

Significant

\section{Non-Word Reading}

Speed

Significant Not

Significant
Text Reading Accuracy

Text Reading Speed

Significant Not
Significant Not Significant
Text Reading

Comprehension

Significant Not Significant

Literacy

Precursors

( $\mathrm{n}=$ number of

studies)

\begin{tabular}{ll}
\hline $\begin{array}{l}\text { Phonological } \\
\text { Awareness }\end{array}$ & $1 *$ Chinese-English; \\
$(\mathrm{n}=15)$ & $2 *$ Chinese \\
& (dominant)-English \\
and English & (dominant)-Chinese; \\
& $3 *$ Chinese-English; \\
& $4 *$ Heterogeneous- \\
& English; \\
& $+7 *$ French-English, \\
& and Other-English; \\
& $8 *$ Heterogeneous \\
& (Malay; Tamil; \\
& Mandarin Chinese)- \\
& English
\end{tabular}

9*Russian-Hebrew;

14*Hindi-English;

$9 *$ Russian-

Hebrew;

14*Hindi-English;
9*Russian-

Hebrew;

9*Russian-

Hebrew; 
PRECURSORS OF BILINGUAL LITERACY DEVELOPMENT

medRxiv preprint doi: https:///doi.org/10.1101/2021.08. 18.21262243; this version posted August 23, 2021. The copyright holder for this preprint
(which was not certified by peer review) is the authorffunder, who has granted medR xiv a license to display the preprint in perpetuity.

(Which was not certified by peer review) is the authorfunder, who has granted medrix a license to display the preprint in perpetuity.
It is made available under a CC-BY-NC-ND 4.0 International license

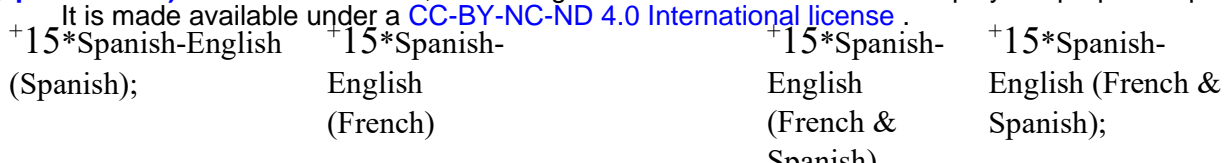

${ }^{+} 15 *$ Spanish- $\quad{ }^{+} 15 *$ Spanish-

English English

${ }^{+} 15 *$ Spanish-

Spanish)

Spanish)

Spanish)

English

Spanish)

$+22 *$ Welsh-English

. Minknd

a; Kikamba-

$+23 *$ Chinese-

English;

$32 *$ Chinese-English

$33 *$ Chinese-English

$33 *$ Chinese-

English

$23 *$ Chinese

Letter 4*Heterogeneous-

Knowledge English;

$(\mathrm{n}=2)$

13*Maya-Spanish

Serial Recall

$4 *$ Heterogeneous-

Englist

$(\mathrm{n}=4)$

$22 *$ Welsh-English;

$33 *$ Chinese-English

10*Spanish-English;

Language/Listen

Comprehension

11*Spanish-English;

$16 *$ Logographic-

$(\mathrm{n}=3)$

$$
\text { English and }
$$

16*Logographic-

English and

$11 *$ Spanish-

English;

$16 *$ Logograp

hic-English

and

Alphabetic-
English 
PRECURSORS OF BILINGUAL LITERACY DEVELOPMENT

medRxiv preprint doi: https:///doi.org/10.1101/2021.08.18.21262243; this version posted August 23,2021 . The copyright holder for this preprin
(which was not certified by peer review) is the authorffunder, who has granted medRxiv a license to display the preprint in perpetuity.

Receptive

$1 *$ It is made available under a CC-BY-NC-ND 4.0 International license.

$3 *$ Chinese-English;

${ }^{+} 19 *$ Mijikend

$(\mathrm{n}=14)$

$8 *$ Heterogeneou

(Malay; Tamil;

Mandarin Chinese)-

$10 *$ Spanish-English

11 *Spanish-English;

16*Logographic-

English and

Alphabetic-English;

$16 *$ Logographic-

English and

Alphabetic-English

$11 *$ Spanish-

English;

16*Logographi

c-English and

Alphabetic-

English;

$22 *$ Welsh-English;

$+23 *$ Chinese-
English

21 *Urdu-

orwegian;

$23 *$ Chinese-

English;

$25 *$ Welsh-

English;

$26 *$ Heterogeno

us-Dutch

$25 *$ Welsh-English; 
PRECURSORS OF BILINGUAL LITERACY DEVELOPMENT

medRxiv preprint doi: https:///doi.org/10.1101/2021.08.18.21262243; this version posted August 23, 2021. The copyright holder for this preprint
(which was not certified by peer review) is the authorffunder, who has granted medR xiv a license to display the preprint in perpetutity.

made available under a CC-BY

Morphological

$1 *$ Chinese-

Awarenes

English

$(\mathrm{n}=5)$

3*Chinese-English;

5*Malay-English

$5 *$ Malay-

$+23 *$ Chinese-

English;

$33^{*}$ Chinese-English

$33 *$ Chinese-

English

$+23 *$ Chinese

English;

$33 *$ Chinese-

English

$33 *$ Chinese

17*Italian-

English

(Italian and

$33 *$ Chinese

English

English

$33 *$ Chinese-

English 
PRECURSORS OF BILINGUAL LITERACY DEVELOPMENT

medRxiv preprint doi: https:///doi.org/10.1101/2021.08. 18.21262243; this version posted August 23, 2021. The copyright holder for this preprint
(which was not certified by peer review) is the authorffunder, who has granted medR xiv a license to display the preprint in perpetuity.

Semantic

Awareness

$(\mathrm{n}=3)$

$9 *$ Russian-

9*Russian-

$9 *$ Russian-

$9 *$ Russian-

Hebrew

$26 *$ Heterogen

$\begin{array}{ll}\text { Spelling } & 4 * \text { Heterogeneous- } \\ (\mathrm{n}=2) & \text { English; } \\ & 17 * \text { Italian-English } \\ & \text { (Italian and English) }\end{array}$

$17 *$ Italian-English

(Italian and

\section{VA Span}

(Italian and English)

English)

$(\mathrm{n}=1)$

$15 *$ Spanish-English

(French \& Spanish)

$\begin{array}{ll}15 * \text { Spanish- } & 15 * \text { Spanish- } \\ \text { English } & \text { English (French \& } \\ \text { (French \& } & \text { Spanish) }\end{array}$

$15 *$ Spanish-
English

$\begin{array}{ll}\text { English (French \& } & \begin{array}{l}\text { English } \\ \text { (French \& } \\ \text { Spanish) }\end{array} \\ \text { Spanish) }\end{array}$

$15 *$ Spanish-

English

$15 *$ Spanish- $\quad 15 *$ Spanish-

(French \&

(French)

English

English

\section{Orthographic $\quad 2 *$ Younger English $\quad 2 *$ Younger \\ Processing (dominant)-Chinese Chinese \\ $(\mathrm{n}=1) \quad$ and Older Chinese $\quad$ (dominant)- \\ Older English \\ Chinese}

Environmental $\quad 4 *$ Heterogeneous-

Print Awareness Englis

$(\mathrm{n}=1)$

\section{Name Writing \\ 13*Maya-Spanish}

$(\mathrm{n}=1)$

Sub-

Lexical/Phonolo

gical Speech

Perception Task

$(\mathrm{n}=1)$

Sentence

Priming Task

$(\mathrm{n}=1)$

Note $^{*}=$ specifies type of bilingual language background; ${ }^{+}=$Studies $(7,15,19,22,23,24)$ that only assessed phonemic awareness. 
PRECURSORS OF BILINGUAL LITERACY DEVELOPMENT

medRxiv preprint doi: https:///doi.org/10.1101/2021.08. 18.21262243; this version posted August 23, 2021. The copyright holder for this preprint
(which was not certified by peer review) is the authorffunder, who has granted medRxiv a license to display the preprint in perpetuity.

\section{Table 8A}

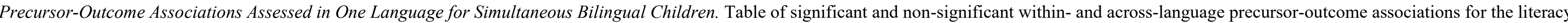

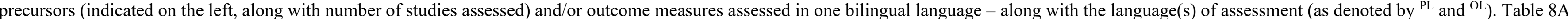
indicates significant and non-significant associations between given literacy precursors (indicated on the left) and literacy outcome measures, as reported by the individual studies listed in Table 4.

\section{Literacy Precursors and Outcomes Assessed in 1 Bilingual Languag}

\section{Literacy Precursors Assessed in Both Bilingual Languages}

and Outcomes Assessed in 1 Bilingual Language

Literacy Precursors Assessed in 1 Bilingual Language

$\begin{array}{llllll}\text { Significant } & \text { Significant } & \text { Not Significant } & \text { Significant Within- } & \text { Significant Across-Language } & \text { Significant Within- } \\ \text { Within-Language } & \text { Across- } & \text { (Within-Language) } & \text { Language } & \text { Language }\end{array}$

Literacy Precursors

( $\mathrm{n}=$ number of studies)

Phonological

Awareness $(n=10)$

$2^{\text {PL \& OL }}$ (English);

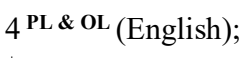

${ }^{+} 7$ (Heterogenous-

PL \& OL (English);

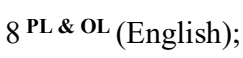

$9^{\text {PL \& OL }}$ (Hebrew);

${ }^{+} 19^{\text {PL \& OL }}$ (Kiswahili);

$+23^{\text {PL \& OL (English) }}$

${ }^{+} 24^{\text {PL \& OL }}$ (German)

\section{Letter Knowledg}

$4^{\text {PL \& oL (English) }}$

$(\mathrm{n}=1)$

Serial Recall $(n=3)$

$4^{\text {PL \& OL (English) }}$

(Within-Language)

Significant Within-

$\begin{array}{ll}1^{\mathrm{PL}} \text { (Chinese and English) } & 1^{\mathrm{PL}} \text { (Chinese and English) } \\ { }^{\mathrm{OL}} \text { (English); } & { }^{\mathrm{OL}} \text { (English); } \\ 32^{\mathrm{PL} \& \text { OL }} \text { (Chinese and English) } & 32^{\mathrm{PL}} \text { (Chinese and English) }\end{array}$

oL (English)
$26^{\mathrm{PL} \& \text { OL }}$ (Dutch)

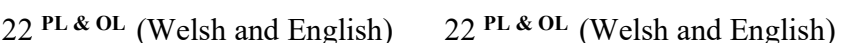

Oral

Language/Listening

Comprehension $(\mathrm{n}=1)$ 
PRECURSORS OF BILINGUAL LITERACY DEVELOPMENT

medRxiv preprint doi: https:///doi.org/10.1101/2021.08. 18.21262243; this version posted August 23, 2021. The copyright holder for this preprint
(which was not certified by peer review) is the authorffunder, who has granted medRxiv a license to display the preprint in perpetuity.

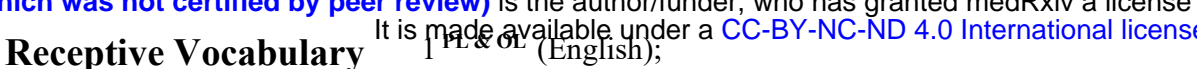

$(\mathrm{n}=9)$

$$
\begin{aligned}
& 16^{\text {PL \& OL (English); }} \\
& 19^{\text {PL \& oL }} \text { (Kiswahili); } \\
& 23^{\text {PL \& oL }} \text { (English); } \\
& 26^{\text {PL \& OL }} \text { (Dutch) }
\end{aligned}
$$

Expressive Vocabulary $2^{\text {PL \& OL (German) }}$

$(\mathrm{n}=2)$

\section{Syntactic Awareness}

$(\mathrm{n}=1)$

\begin{abstract}
Morphological
\end{abstract}
Awareness ( $\mathrm{n}=3$ )

\section{Working Memory}

$(\mathrm{n}=1)$

\section{Verbal Short-Term}

Memory $(\mathrm{n}=1)$

\section{Non-Verbal}

Intelligence $(\mathrm{n}=3)$

\section{Word/Non-Word}

Decoding $(\mathrm{n}=5)$

$$
23^{\text {PL \& OL }} \text { (English) }
$$

\section{$1^{\text {PL }}$ (Chinese)}

OL (English)

ns across language associations (different

languages assessed for literacy precursor and

outcome measure)

$31^{\text {PL \& OL }}$ (English)

$$
4^{\text {PL \& OL }} \text { (English) }
$$

$31^{\text {oL }}$ (English)

32 oL (English)

$$
\begin{aligned}
& 21^{\text {PL \& OL (Norwegian); }} 23^{\text {PL \& OL (English); }} \\
& 24 \text { PL \& OL (German) }
\end{aligned}
$$$$
30^{\mathrm{PL} \& \text { OL }} \text { (Dutch) }
$$

$8^{\mathrm{PL}}$ (Malay, Tamil or

Mandarin-Chinese and Englis

oL (English);

$21^{\mathrm{PL}}$ (Norwegian and Urdu)

oL (Norwegian)

$30^{\mathrm{PL}}$ (Turkish and Dutch)

${ }^{\text {oL }}$ (Dutch)

\section{${ }^{\mathrm{PL}}$ (Spanish and English)}

oL (English)
$21^{\mathbf{P L}}$ (Norwegian and Urdu)

${ }^{\mathrm{oL}}$ (Norwegian)
$22^{\mathrm{PL}}$ (Welsh)

oL (Welsh and English)

$22^{\mathrm{PL}}$ (Welsh)

and English)

oL (Welsh and English)
${ }^{\text {PL }}$ (English)

oL (Malay and English) $5^{\text {PL }}$ (English)

oL (Malay and English) 
PRECURSORS OF BILINGUAL LITERACY DEVELOPMENT

medRxiv preprint doi: hitps:///doi.org/10.1101/2021.08.18.21262243; this version posted August 23, 2021. The copyright holder for this preprint
(which was not certified by peer review) is the authorffunder, who has granted medRxiv a license to display the preprint in perpetuity.

Semantic Awareness It is made available under a CC-BY-NC-ND 4.0 Internatighal license ${ }_{\text {Heterogenous-English bilinguals) }}$

$(n=3)$

PL \& OL (English);

$9^{\text {PL \& OL }}$ (Hebrew)

$26^{\text {PL \& OL (Dutch) }}$

Spelling $(n=1)$

$4^{\text {PL \& OL (English) }}$

Orthographic

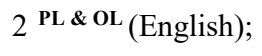

Processing $(\mathrm{n}=1)$

Environmental Print

Awareness $(\mathrm{n}=1)$

Sub-

Lexical/Phonological

Speech Perception

Task $(\mathrm{n}=1)$

Sentence Priming Task

$29^{\text {PL \& OL (Hebrew) }}$

$(n=1)$

Different

languages assessed

for literacy

outcome measure

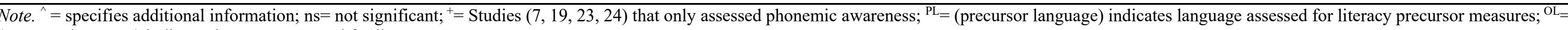
(outcome language) indicates language assessed for literacy outcome measures. 
PRECURSORS OF BILINGUAL LITERACY DEVELOPMENT

medRxiv preprint doi: httrss://doi. org/10.1101/2021.08.18.21262243; this version posted August 23, 2021. The copyright holder for this preprint
(which was not certified by peer review) is the authorffunder, who has granted medRxiv a license to display the preprint in perpetuity.

Table 8B

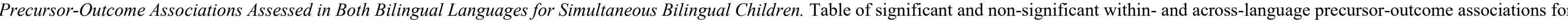

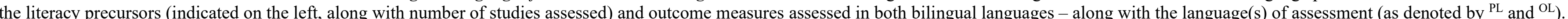
Table 8B indicates significant and non-significant associations between given literacy precursors (indicated on the left) and literacy outcomes, as reported by the individual studies listed in Table 4 .

Literacy Precursors and Outcomes Assessed in Both Bilingual Languages

Significant Within-Language for 1 Significant Within-Language Bilingual Language

\section{Significant Within-Language} for Both Bilingual Languages
Significant Across-Language for 1 Bilingual Language
Significant Across-Language for Both Bilingual Languages
Not

Significant

(Across-Language)
Significant

\section{Literacy Precursors}

$(\mathrm{n}=$ number of

studies)

\section{Phonological}

Awareness ( $\mathrm{n}=6$ )

${ }^{+} 7$ (French-English bilinguals)

$3^{\text {PL \& OL }}$ (Chinese and English);

$14^{\mathrm{PL}}$ (neural study) ${ }^{\&} \mathrm{OL}_{\text {(Hindi and }}$

$$
\text { English); }
$$

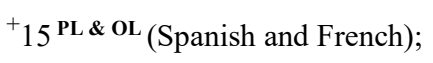

${ }^{+} 22$ PL \& oL (Welsh and English)

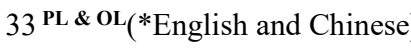

\section{Letter Knowledge}

$(\mathrm{n}=1)$

\section{Serial Recall}

$(\mathrm{n}=1)$

Oral

Language/Listening

Comprehension

$(n=2)$

Receptive

Vocabulary $(n=5)$ $13^{\text {PL \& OL }}$ (Maya and Spanish)

$33^{\text {PL \& OL (English and Chinese) }}$

$33^{\mathrm{PL}} \& \mathbf{O L}$ (English and Chinese)

*Chinese serial recall - English reading
$3^{\mathrm{RL} \& \mathrm{OL}}$ (Chinese and

English);

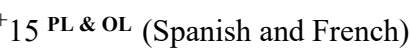

22 PL \& OL (Welsh and English)

$33^{\mathrm{PL} \& \mathrm{OL}}$ (English and

Chinese)

13 PL \& OL (Maya and Spanish)

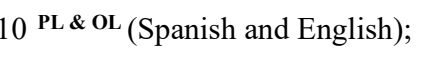

$11^{\text {PL \& OL (Spanish and English) }}$

$3^{\text {PL \& OL }}$ (Chinese and English);

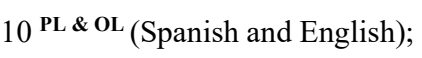

$11^{\mathrm{PL} \& \text { OL }}$ (Spanish and English);

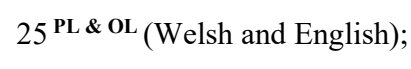

$33^{\text {PL \& OL (English and Chinese) }}$
$10^{\mathrm{PL} \& \text { OL }}$ (Spanish and English)

$11^{\text {PL \& OL (Spanish and English) }}$ 
PRECURSORS OF BILINGUAL LITERACY DEVELOPMENT

medRxiv preprint doi: https:///doi. org/10.1101/2021.08.18.21262243; this version posted August 23,2021 . The copyright holder for this preprin
(which was not certified by peer review) is the authorffunder, who has granted medRxiv a license to display the preprint in perpetuity.

Expressive

Vocabulary $(n=1)$

Syntactic

Awareness ( $\mathrm{n}=2)$

$33^{\left.\text {PL \& } \text { oL }_{(} * \text { English and Chinese }\right)}$

$17^{\mathrm{PL} \& \mathrm{OL}}$ (Italian and English)

English vocabulary - Chinese reading

17 PL \& OL (Italian and English)

*English syntactic awareness- Italian reading

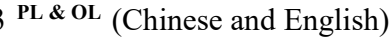

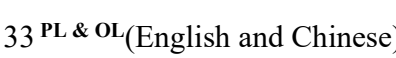

Morphological

Awareness ( $\mathrm{n}=2)$

\section{Working Memory}

$(\mathrm{n}=2)$

Non-Verbal

$33^{\mathrm{PL} \& \mathrm{OL}}\left({ }^{*}\right.$ English and Chinese $)$

Intelligence $(\mathrm{n}=1)$

Word/Non-Word

Decoding $(\mathrm{n}=1)$

Semantic

Awareness ( $\mathrm{n}=1)$

Spelling $(\mathrm{n}=1)$ $33^{\text {PL \& OL (English and Chinese) }}$

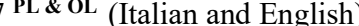

*English working memory- Italian reading;

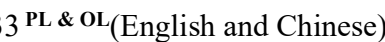

Chinese working memory- English reading

$33^{\mathrm{PL} \& \mathrm{OL} \text { (English and Chinese) }}$

*Chinese non-verbal intelligence vocabulary English reading $33^{\text {PL \& OL }}$ (English and

Chinese)

$3^{\text {PL \& OL }}$ (Chinese and

English);

$33^{\text {PL \& OL }}$ (English and

Chinese)

$33^{\text {PL } \& \text { OL (English and }}$

7(French-Englis

bilinguals

PL \& OL (French and English) 
PRECURSORS OF BILINGUAL LITERACY DEVELOPMENT

medRxiv preprint doi: https:///doiorg/10.1101/2021.08.18.21262243; this version posted August 23, 2021. The copyright holder for this preprint
(which was not certified by peer review) is the author/funder, who has granted medRxiv a license to display the preprint in perpetuity.

VA Span $(n=1)$

It is made available under a CC-BY-NC-ND 4.0 Intepnatiegal lisense

$15^{\text {PL \& OL }}$ (Spanish and French)

Name Writing (n=1) $\quad 13^{\circ \mathrm{L}}$ (*Maya and Spanish)

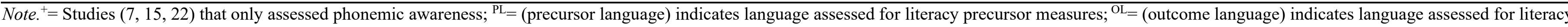

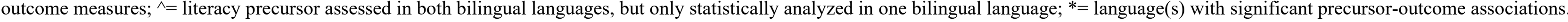




\section{Table 9}

Correlational Meta-Analyses Results Across Precursor Type, in relation to Word and Non-Word Reading. We listed correlational effect size, along with number of studies (n), 95\% CI, p-values and heterogeneity values, for phonological awareness, vocabulary and morphological awareness, in relation to word/non-word reading. When possible, we conducted two analyses, based on the assessment language (i.e., whether assessed in English only, or another language only).

\begin{tabular}{|c|c|c|c|c|c|c|c|c|}
\hline \multirow{3}{*}{$\begin{array}{l}\text { Literacy } \\
\text { Precursor }\end{array}$} & \multirow[t]{3}{*}{ n (studies) } & \multirow{3}{*}{$\begin{array}{c}\text { Effect Size } \\
\text { (Correlation) }\end{array}$} & \multicolumn{2}{|c|}{$95 \%$ CI } & \multirow[t]{3}{*}{$\mathbf{p}$} & \multicolumn{2}{|c|}{ Heterogeneity } & \multirow[t]{3}{*}{ Figure } \\
\hline & & & & & & $\mathrm{I} 2$ & $\mathrm{p}$ & \\
\hline & & & Lower & Upper & & & & \\
\hline \multicolumn{9}{|l|}{$\begin{array}{c}\text { Phonological } \\
\text { Awareness }\end{array}$} \\
\hline English & 15 & 0.5068 & 0.4055 & 0.5958 & $*<0.0001$ & $64.1 \%$ & 0.0004 & 2 \\
\hline $\begin{array}{l}\text { Other Language } \\
\text { (Non-English) }\end{array}$ & 5 & 0.3563 & 0.1169 & 0.5565 & $* 0.0042$ & $58.8 \%$ & 0.0455 & 3 \\
\hline \multicolumn{9}{|l|}{ Vocabulary: } \\
\hline English & 12 & 0.4027 & 0.2862 & 0.5075 & $*<0.0001$ & $60.9 \%$ & 0.0031 & 4 \\
\hline $\begin{array}{l}\text { Other Language } \\
\text { (Non-English) }\end{array}$ & 5 & 0.3133 & 0.1383 & 0.4692 & $* 0.0006$ & $53.5 \%$ & 0.0719 & 5 \\
\hline $\begin{array}{c}\text { Morphological } \\
\text { Awareness }\end{array}$ & 6 & 0.5005 & 0.1441 & 0.7420 & $* 0.0078$ & $85.8 \%$ & $<0.0001$ & 6 \\
\hline
\end{tabular}


PRECURSORS OF BILINGUAL LITERACY DEVELOPMENT

\section{Table 10}

Correlational Meta-Analyses Results Across Precursor Type, in relation to Text Reading Comprehension. We listed correlational effect size, along with number of studies (n), 95\% CI, p-values and heterogeneity values, for vocabulary and word/non-word decoding, in relation to text comprehension.

\begin{tabular}{|c|c|c|c|c|c|c|c|c|}
\hline \multirow{3}{*}{$\begin{array}{l}\text { Literacy } \\
\text { Precursor }\end{array}$} & \multirow[t]{3}{*}{ n (studies) } & \multirow{3}{*}{$\begin{array}{c}\text { Effect Size } \\
\text { (Correlation) }\end{array}$} & \multicolumn{2}{|c|}{$95 \%$ CI } & \multirow[t]{3}{*}{$\mathbf{p}$} & \multicolumn{2}{|c|}{ Heterogeneity } & \multirow[t]{3}{*}{ Figure } \\
\hline & & & & & & $\mathrm{I} 2$ & $\mathrm{p}$ & \\
\hline & & & Lower & Upper & & & & \\
\hline Vocabulary & 8 & 0.5706 & 0.3669 & 0.7221 & $*<0.0001$ & $77.9 \%$ & $<0.0001$ & 7 \\
\hline $\begin{array}{l}\text { Word and Non- } \\
\text { Word Decoding }\end{array}$ & 5 & 0.6741 & 0.3705 & 0.8476 & $* 0.0002$ & $90.3 \%$ & $<0.0001$ & 8 \\
\hline
\end{tabular}

Note $^{*}=$ significant $p$-value $<0.05$. See Figures $7-8$ for corresponding random-effect models. 


\section{Table 11}

Correlational Meta-Analyses Results for Phonological Awareness in relation to Word/Non-Word Reading, based on Type of Literacy Precursor and Outcome Measure Testing, Writing System, and Country of Assessment. We listed correlational effect size, along with number of studies (n), test for subgroup differences, 95\% CI, p-values and heterogeneity values, for phonological awareness in relation to word/non-word reading as an outcome measure, based on the type of testing (i.e., whether phonological awareness and word/non-word reading measures were assessed in the same [within-language] or different [across-language] language), writing system (i.e., whether simultaneous bilinguals, assessed on phonological awareness and word/non-word reading measures in an alphabetic language [all within-language assessments were conducted in English, except for Hebrew in study 9 and French in study 15], spoke syllabic-alphabetic or alphabetic-alphabetic bilingual language combinations), and country of assessment (i.e., whether Chinese-English simultaneous bilinguals were assessed, on English phonological awareness and word/non-word reading measures, in Canada/US or Singapore).

\begin{tabular}{|c|c|c|c|c|c|c|c|c|c|c|}
\hline \multirow[t]{3}{*}{ Subgroup } & \multirow{3}{*}{$\begin{array}{c}n \\
\text { (studies) }\end{array}$} & \multirow{2}{*}{\multicolumn{2}{|c|}{$\begin{array}{c}\text { Test for } \\
\text { Subgroup } \\
\text { Differences } \\
\text { (Random } \\
\text { Effects Model) }\end{array}$}} & \multirow{3}{*}{$\begin{array}{l}\text { Effect } \\
\text { Size } \\
\text { (Correl } \\
\text { ation) }\end{array}$} & \multicolumn{2}{|c|}{$95 \% \mathrm{CI}$} & \multirow{3}{*}{$\begin{array}{c}\text { p (Overall } \\
\text { Model) }\end{array}$} & \multicolumn{2}{|c|}{ Heterogeneity } & \multirow[t]{3}{*}{ Figure } \\
\hline & & & & & \multirow[b]{2}{*}{ Lower } & \multirow[b]{2}{*}{ Upper } & & \multirow[t]{2}{*}{$\mathrm{I} 2$} & \multirow[t]{2}{*}{$\mathrm{p}$} & \\
\hline & & $\mathrm{Q}$ & $\mathrm{p}$ & & & & & & & \\
\hline $\begin{array}{c}\text { Testing } \\
\text { (within vs. } \\
\text { across } \\
\text { languages) }\end{array}$ & 22 & 2.48 & 0.1154 & & & & & & & 9 \\
\hline Overall Model & & & & 0.4713 & 0.3850 & 0.5494 & $<0.0001$ & $60.5 \%$ & 0.0001 & \\
\hline $\begin{array}{l}\text { Within- } \\
\text { Language }\end{array}$ & 17 & & & 0.5031 & 0.4098 & 0.5860 & & $59.0 \%$ & & \\
\hline $\begin{array}{l}\text { Across- } \\
\text { Language }\end{array}$ & 5 & & & 0.3485 & 0.1577 & 0.5142 & & $41.6 \%$ & & \\
\hline
\end{tabular}


PRECURSORS OF BILINGUAL LITERACY DEVELOPMENT

\begin{tabular}{|c|c|c|c|c|c|c|c|c|c|c|}
\hline $\begin{array}{l}\text { Writing } \\
\text { System }\end{array}$ & 16 & 3.97 & $* 0.0463$ & & & & & & & 10 \\
\hline Overall Model & & & & 0.5161 & 0.4220 & 0.5992 & $<0.0001$ & $58.7 \%$ & 0.0016 & \\
\hline $\begin{array}{l}\text { Syllabic- } \\
\text { Alphabetic }\end{array}$ & 11 & & & 0.5708 & 0.4813 & 0.6485 & & $27.5 \%$ & & \\
\hline $\begin{array}{l}\text { Alphabetic- } \\
\text { Alphabetic }\end{array}$ & 5 & & & 0.3763 & 0.1781 & 0.5451 & & $73.0 \%$ & & \\
\hline $\begin{array}{l}\text { Country of } \\
\text { Assessment }\end{array}$ & 11 & 0.09 & 0.7610 & & & & & & & 11 \\
\hline Overall Model & & & & 0.5708 & 0.4813 & 0.6485 & $<0.0001$ & $27.5 \%$ & 0.1827 & \\
\hline Canada/US & 6 & & & 0.5813 & 0.4453 & 0.6910 & & $46.5 \%$ & & \\
\hline Singapore & 5 & & & 0.5553 & 0.4322 & 0.6581 & & $0.0 \%$ & & \\
\hline
\end{tabular}

Note $^{*}=$ significant $\mathrm{p}$-value $<0.05$. See Figures 9-11 for corresponding random-effect models. 


\section{Table 12}

Correlational Meta-Analyses Results for Vocabulary in relation to Word/Non-Word Reading, based on Type of Literacy Precursor and Outcome Measure Testing. We listed correlational effect size, along with number of studies (n), test for subgroup differences, 95\% CI, p-values and heterogeneity values, for vocabulary in relation to word/non-word reading as an outcome measure, based on the type of testing (i.e., whether vocabulary and word/non-word reading measures were assessed in the same [within-language] or different [across-language] language).

\begin{tabular}{|c|c|c|c|c|c|c|c|c|c|c|}
\hline \multirow[t]{3}{*}{ Subgroup } & \multirow{3}{*}{$\begin{array}{c}\mathbf{n} \\
\text { (studies) }\end{array}$} & \multirow{2}{*}{\multicolumn{2}{|c|}{$\begin{array}{c}\text { Test for } \\
\text { Subgroup } \\
\text { Differences } \\
\text { (Random } \\
\text { Effects Model) }\end{array}$}} & \multirow{3}{*}{$\begin{array}{c}\text { Effect Size } \\
\text { (Correlati } \\
\text { on) }\end{array}$} & \multicolumn{2}{|c|}{$95 \% \mathrm{CI}$} & \multirow{3}{*}{$\begin{array}{l}\text { p (Overall } \\
\text { Model) }\end{array}$} & \multicolumn{2}{|c|}{ Heterogeneity } & \multirow[t]{3}{*}{ Figure } \\
\hline & & & & & & & & $\mathbf{I 2}$ & $\mathbf{p}$ & \\
\hline & & $\mathrm{Q}$ & $\mathrm{p}$ & & Lower & Upper & & & & \\
\hline $\begin{array}{l}\text { Testing (within vs. } \\
\text { across languages) }\end{array}$ & 18 & 5.32 & $* 0.0210$ & & & & & & & 12 \\
\hline Overall Model & & & & 0.3254 & 0.2135 & 0.4289 & $\mathrm{p}<0.0001$ & $63.8 \%$ & 0.0001 & \\
\hline Within-Language & 11 & & & 0.4221 & 0.2889 & 0.5392 & & $54.0 \%$ & & \\
\hline Across-Language & 7 & & & 0.2026 & 0.0644 & 0.3332 & & $58.3 \%$ & & \\
\hline
\end{tabular}

Note $^{*}=$ significant $\mathrm{p}$-value $<0.05$. See Figure 12 for corresponding random-effect model. 
PRECURSORS OF BILINGUAL LITERACY DEVELOPMENT

medRxiv preprint doi: https:///doi.org/10.1101/2021.08.18.21262243; this version posted August 23, 2021. The copyright holder for this preprint
(which was not certified by peer review) is the authorffunder, who has granted medRxiv a license to display the preprint in perpetuity.

Table 13

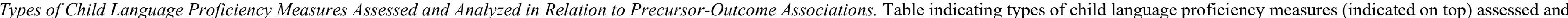
analyzed in the reviewed studies (listed in Table 4), along with studies that assessed receptive and/or expressive vocabulary as a literary precursor. These measures are presented in relation to precursor-outcome associations for simultaneous bilinguals in each study.

\begin{tabular}{|c|c|c|c|c|c|c|c|c|c|}
\hline \multicolumn{3}{|c|}{ Parent Questionnaire or Interview } & \multirow{2}{*}{$\begin{array}{l}\text { Child Language } \\
\text { Interview } \\
\text { Assessed and Did } \\
\text { Not Analyze }\end{array}$} & \multirow{3}{*}{$\begin{array}{l}\text { Teacher } \\
\text { Questionnaire, } \\
\text { Interview or } \\
\text { Classroom } \\
\text { Observations } \\
\\
\text { Assessed and Did } \\
\text { Not Analyze }\end{array}$} & \multirow{2}{*}{$\begin{array}{c}\text { Oral } \\
\text { Language/Listening } \\
\text { Comprehension or } \\
\quad \text { Production } \\
\text { Screening Test } \\
\\
\text { Assessed and Did } \\
\text { Not Analyze }\end{array}$} & \multicolumn{2}{|c|}{$\begin{array}{l}\text { Word and Non-Word Reading } \\
\text { Screening Test }\end{array}$} & \multirow[b]{2}{*}{$\begin{array}{l}\text { Assessed and } \\
\text { Analyzed (in } \\
\text { relation to other } \\
\text { literacy } \\
\text { precursors) }\end{array}$} & \multirow[b]{2}{*}{$\begin{array}{l}\text { Assessed and } \\
\text { Analyzed (in } \\
\text { relation to literacy } \\
\text { outcome } \\
\text { measures) }\end{array}$} \\
\hline Assesse & d Analyzed & $\begin{array}{l}\text { Assessed and Did } \\
\text { Not Analyze }\end{array}$ & & & & $\begin{array}{l}\text { Assessed and } \\
\text { Analyzed }\end{array}$ & $\begin{array}{l}\text { Assessed and Did } \\
\text { Not Analyze }\end{array}$ & & \\
\hline Not Significant & Significant & & & & & Significant & & Significant & Significant \\
\hline $12 ; 28 ; 31$ & $\begin{array}{l}32 \text { significant in } \\
\text { relation to reading } \\
\text { performance (Chinese } \\
\text { character recognition); } \\
\text { did not analyze in } \\
\text { relation to precursor- } \\
\text { outcome associations }\end{array}$ & $\begin{array}{l}1 ; 2 ; 3 ; 7 ; 8 ; 10 \\
11 ; 13 ; 14 ; 15 \\
16 ; 18 ; 20 ; 21 \\
23 ; 25 ; 27 ; 29 \\
30 ; 33\end{array}$ & $20 ; 24 ; 26$ & $8 ; 14 ; 15 ; 24 ; 27$ & $\begin{array}{l}7 ; 10 ; 11 ; 14 ; 20 ; \\
24\end{array}$ & $\begin{array}{l}17 \wedge \text { significant in } \\
\text { relation to literacy } \\
\text { precursors (English } \\
\text { and Italian syntactic } \\
\text { awareness and } \\
\text { spelling, but not } \\
\text { working memory) } \\
\text { and reading } \\
\text { performance } \\
\text { (English and Italian } \\
\text { word and non-word } \\
\text { reading accuracy); } \\
\text { did not analyze in } \\
\text { relation to } \\
\text { precursor-outcome } \\
\text { associations }\end{array}$ & 14 & $\begin{array}{l}1^{\mathrm{RV}} ; 3^{\mathrm{RV}} ; 8^{\mathrm{RV}} \\
16^{\mathrm{RV}} ; 23^{\mathrm{RV}} \\
33^{\mathrm{RV} \& \mathrm{EV}}\end{array}$ & $\begin{array}{l}1^{\mathrm{RV}} ; 3^{\mathrm{RV}} ; 6^{\mathrm{EV}} ; \\
8^{\mathrm{RV}} ; 10^{\mathrm{RV}} ; \\
11^{\mathrm{RV}} ; 16^{\mathrm{RV}} ; 19^{\mathrm{RV}} ; \\
21^{\mathrm{RV}} ; 22^{\mathrm{RV}} ; \\
23^{\mathrm{RV}} ; 24^{\mathrm{EV}} ; \\
25^{\mathrm{RV}} ; 26^{\mathrm{RV}} ; \\
30^{\mathrm{RV}} ; 33^{\mathrm{RV} \& \mathrm{EV}}\end{array}$ \\
\hline
\end{tabular}

Note. ${ }^{\mathrm{RV}}=$ assessed receptive vocabulary; ${ }^{\mathrm{EV}}=$ assessed expressive vocabulary; ${ }^{\wedge}=$ specifies additional information. 
medRxiv preprint doi: https://doi.org/10.1101/2021.08.18.21262243; this version posted August 23, 2021. The copyright holder for this preprint (which was not certified by peer review) is the author/funder, who has granted medRxiv a license to display the preprint in perpetuity.

It is made available under a CC-BY-NC-ND 4.0 International license .

\section{PRECURSORS OF BILINGUAL LITERACY DEVELOPMENT}

\section{Figures}

\section{Figure 1}

Preferred Reporting Items for Systematic Reviews and Meta-Analyses (PRISMA) Flow Diagram for the Systematic Literature Review Search. PRISMA Flow Diagram specifying number of studies included at title/abstract, full-text, additional Google Scholar and manual citation search, and critical appraisal levels of screening.

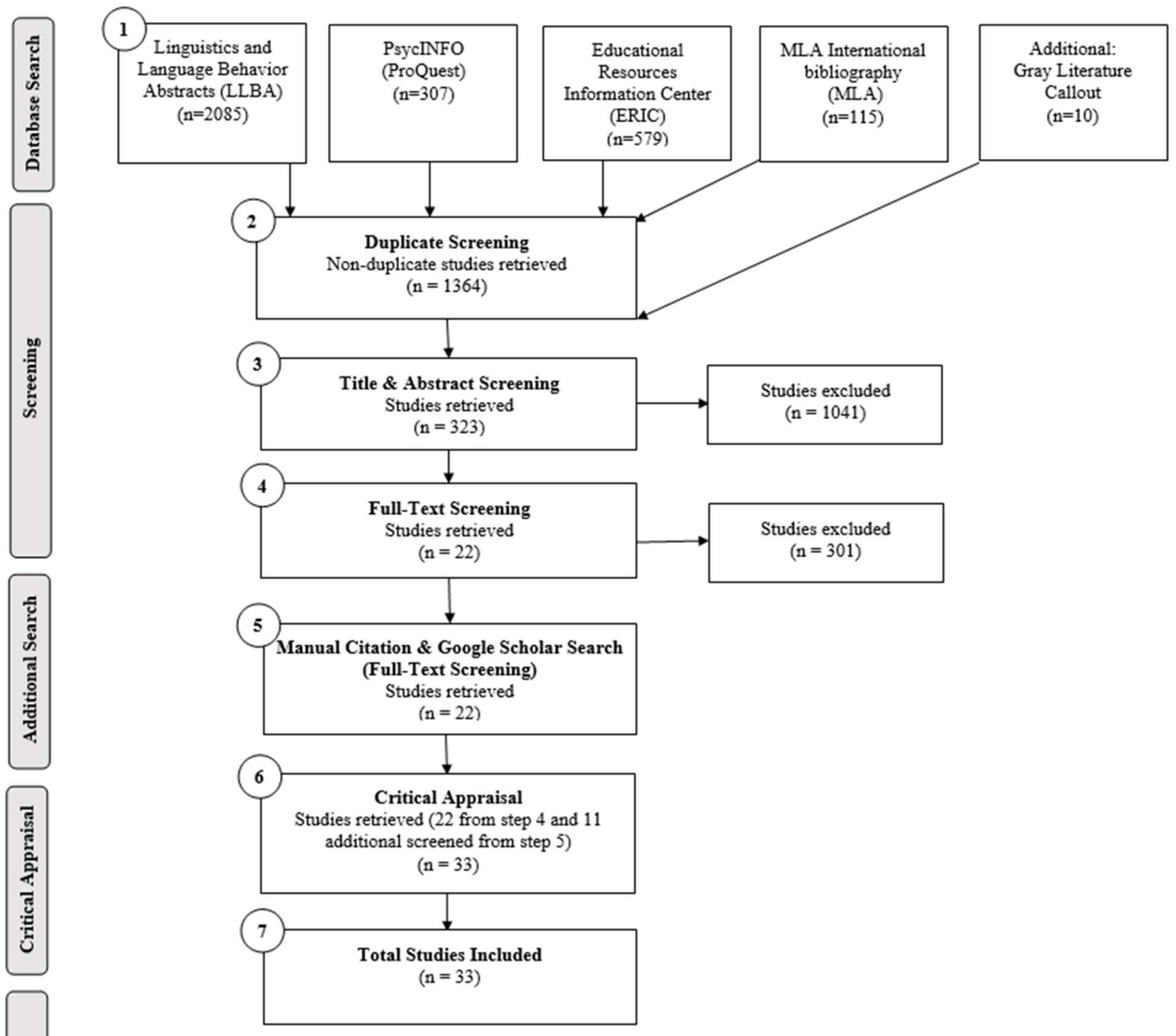


medRxiv preprint doi: https://doi.org/10.1101/2021.08.18.21262243; this version posted August 23, 2021. The copyright holder for this preprint (which was not certified by peer review) is the author/funder, who has granted medRxiv a license to display the preprint in perpetuity. It is made available under a CC-BY-NC-ND 4.0 International license .

\section{PRECURSORS OF BILINGUAL LITERACY DEVELOPMENT}

\section{Figure 2}

Meta-Analysis for Phonological Awareness in relation to Word and Non-Word Reading (English language only). Forestplot indicating correlational effect size for random-effects model ( $\mathrm{r}=$ 0.5068; 95\% CI: 0.4055, 0.5958; $\mathrm{p}<0.0001)$ and individual correlations/study between phonological awareness and word/non-word reading, for within-language studies that only assessed phonological awareness and word/non-word reading measures in English.

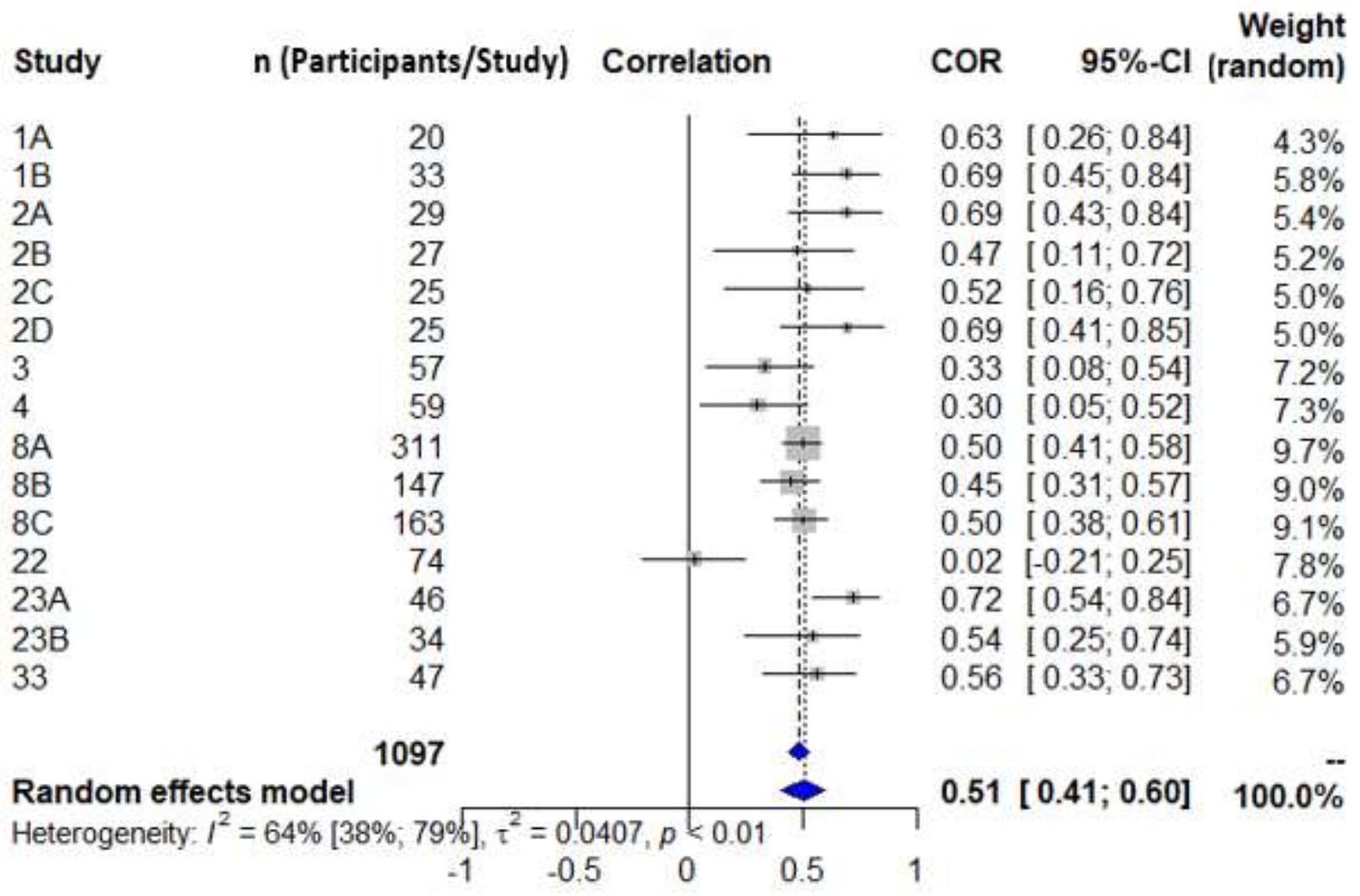


medRxiv preprint doi: https://doi.org/10.1101/2021.08.18.21262243; this version posted August 23, 2021. The copyright holder for this preprint (which was not certified by peer review) is the author/funder, who has granted medRxiv a license to display the preprint in perpetuity. It is made available under a CC-BY-NC-ND 4.0 International license.

\section{PRECURSORS OF BILINGUAL LITERACY DEVELOPMENT}

\section{Figure 3}

Meta-Analysis for Phonological Awareness in relation to Word and Non-Word Reading (Other language only). Forestplot indicating correlational effect size for random-effects model ( $\mathrm{r}=$ 0.3563; 95\% CI: 0.1169, 0.5569; $\mathrm{p}=0.0042$ ) and individual correlations/study between phonological awareness and word/non-word reading, for within-language studies that only assessed phonological awareness and word/non-word reading measures in another (non-English) language.

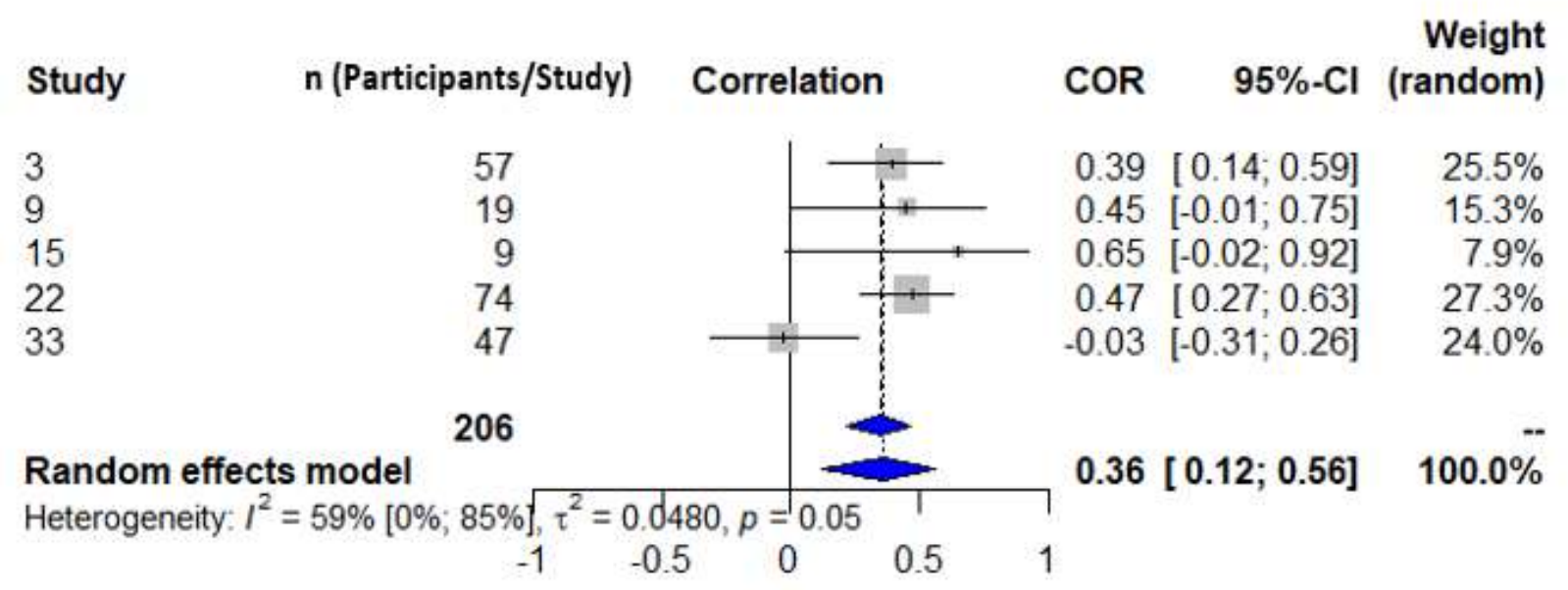


medRxiv preprint doi: https://doi.org/10.1101/2021.08.18.21262243; this version posted August 23, 2021. The copyright holder for this preprint (which was not certified by peer review) is the author/funder, who has granted medRxiv a license to display the preprint in perpetuity. It is made available under a CC-BY-NC-ND 4.0 International license.

\section{PRECURSORS OF BILINGUAL LITERACY DEVELOPMENT}

\section{Figure 4}

Meta-Analysis for Vocabulary in relation to Word and Non-Word Reading (English language only). Forestplot indicating correlational effect size for random-effects model ( $\mathrm{r}=0.4027 ; 95 \%$ CI: $0.2862,0.5075 ; \mathrm{p}<0.0001$ ) and individual correlations/study between vocabulary and word/non-word reading, for within-language studies that only assessed vocabulary and word/non-word reading measures in English.

\begin{tabular}{|c|c|c|c|c|c|c|}
\hline Study & n (Participants/Study) & Correlation & & COR & $95 \%-\mathrm{Cl}$ & $\begin{array}{r}\text { Weight } \\
\text { (random) }\end{array}$ \\
\hline $1 \mathrm{~A}$ & 20 & & & 0.36 & {$[-0.10 ; 0.69]$} & $5.1 \%$ \\
\hline $1 \mathrm{~B}$ & 33 & & $\vdots$ & 0.39 & {$[0.05 ; 0.65]$} & $7.1 \%$ \\
\hline 3 & 57 & & 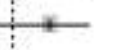 & 0.55 & {$[0.34 ; 0.71]$} & $9.2 \%$ \\
\hline $8 \mathrm{~A}$ & 311 & $\div$ & & 0.20 & {$[0.09 ; 0.30]$} & $13.2 \%$ \\
\hline $8 B$ & 147 & + & & 0.33 & {$[0.18 ; 0.47]$} & $12.0 \%$ \\
\hline $8 C$ & 163 & 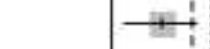 & & 0.20 & {$[0.05 ; 0.34]$} & $12.2 \%$ \\
\hline $16 \mathrm{~A}$ & 26 & & $\longrightarrow$ & 0.78 & {$[0.56 ; 0.90]$} & $6.1 \%$ \\
\hline $16 \mathrm{~B}$ & 13 & & & 0.49 & {$[-0.08 ; 0.82]$} & $3.5 \%$ \\
\hline $23 \mathrm{~A}$ & 46 & & $\longleftarrow$ & 0.44 & {$[0.17 ; 0.65]$} & $8.4 \%$ \\
\hline $23 B$ & 34 & & + & 0.50 & {$[0.19 ; 0.72]$} & $7.2 \%$ \\
\hline 25 & 38 & & & 0.32 & {$[0.00 ; 0.58]$} & $7.6 \%$ \\
\hline 33 & 47 & & & 0.46 & {$[0.20 ; 0.66]$} & $8.5 \%$ \\
\hline \multirow{2}{*}{\multicolumn{2}{|c|}{ Random effects model }} & & & \multirow{3}{*}{\multicolumn{2}{|c|}{$0.40[0.29 ; 0.51]$}} & -. \\
\hline & & & & & & $100.0 \%$ \\
\hline \multirow{2}{*}{\multicolumn{2}{|c|}{ Heterogeneity: $I^{2}=61 \%[27 \% ; 79 \%]$}} & $12, p<0.01$ & 1 & & & \\
\hline & & 0 & 0.5 & 1 & & \\
\hline
\end{tabular}


medRxiv preprint doi: https://doi.org/10.1101/2021.08.18.21262243; this version posted August 23, 2021. The copyright holder for this preprint (which was not certified by peer review) is the author/funder, who has granted medRxiv a license to display the preprint in perpetuity. It is made available under a CC-BY-NC-ND 4.0 International license.

\section{PRECURSORS OF BILINGUAL LITERACY DEVELOPMENT}

\section{Figure 5}

Meta-Analysis for Vocabulary in relation to Word and Non-Word Reading (Other language only). Forestplot indicating correlational effect size for random-effects model $(\mathrm{r}=0.3133 ; 95 \%$ CI: $0.1383,0.4692 ; \mathrm{p}<0.0006)$ and individual correlations/study between vocabulary and word/non-word reading, for within-language studies that only assessed vocabulary and word/non-word reading measures in another (non-English) language.

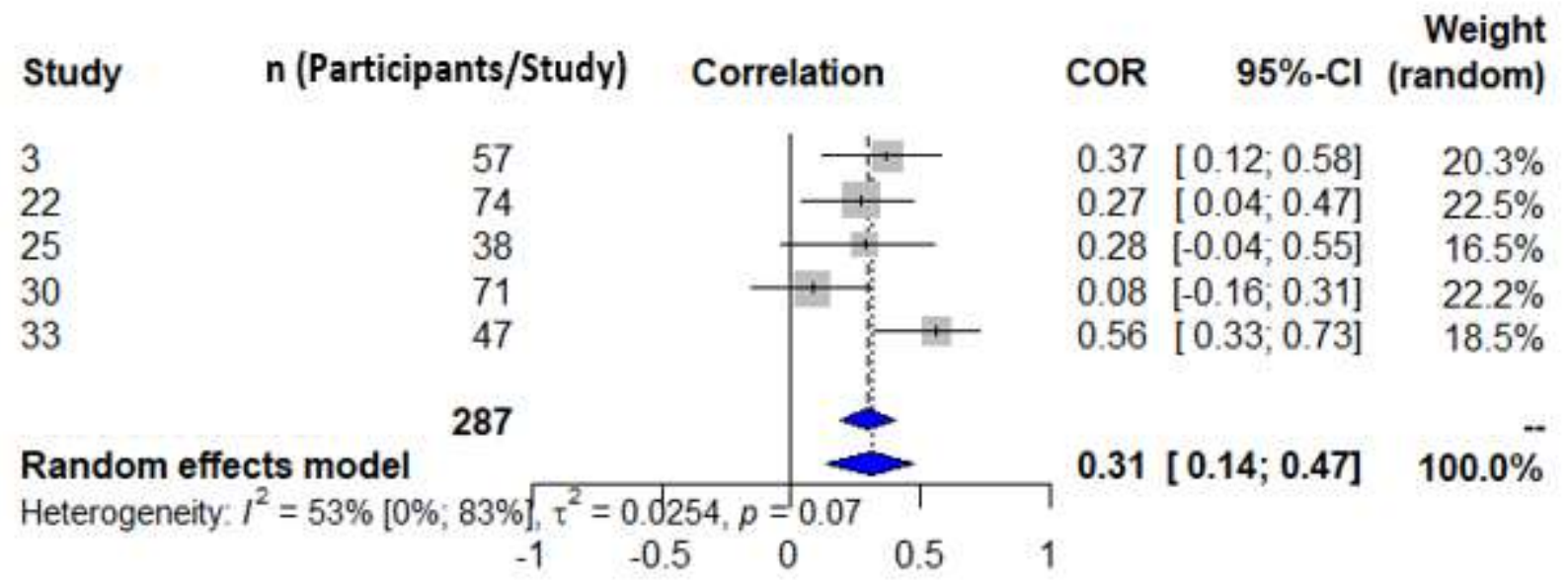


medRxiv preprint doi: https://doi.org/10.1101/2021.08.18.21262243; this version posted August 23, 2021. The copyright holder for this preprint (which was not certified by peer review) is the author/funder, who has granted medRxiv a license to display the preprint in perpetuity. It is made available under a CC-BY-NC-ND 4.0 International license .

\section{PRECURSORS OF BILINGUAL LITERACY DEVELOPMENT}

\section{Figure 6}

Meta-Analysis for Morphological Awareness in relation to Word and Non-Word Reading. Forestplot indicating correlational effect size for random-effects model $(\mathrm{r}=0.5005 ; 95 \% \mathrm{CI}$ : $0.1441,0.7420 ; \mathrm{p}=0.0078)$ and individual correlations/study between morphological awareness and word/non-word reading.

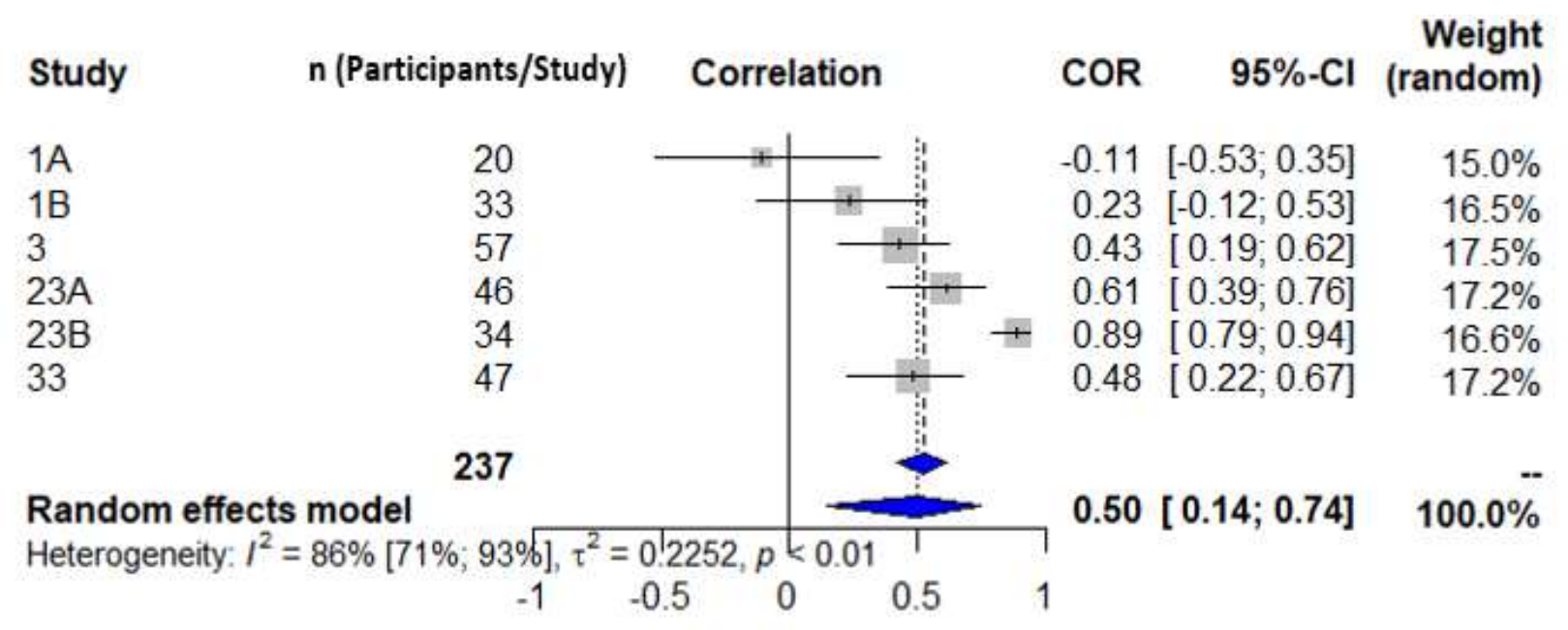


medRxiv preprint doi: https://doi.org/10.1101/2021.08.18.21262243; this version posted August 23, 2021. The copyright holder for this preprint (which was not certified by peer review) is the author/funder, who has granted medRxiv a license to display the preprint in perpetuity. It is made available under a CC-BY-NC-ND 4.0 International license .

\section{PRECURSORS OF BILINGUAL LITERACY DEVELOPMENT}

\section{Figure 7}

Meta-Analysis for Vocabulary in relation to Text Reading Comprehension. Forestplot indicating correlational effect size for random-effects model ( $\mathrm{r}=0.5706 ; 95 \%$ CI: 0.3669, 0.7221; $\mathrm{p}<$ 0.0001 ) and individual correlations/study between vocabulary and text reading comprehension.

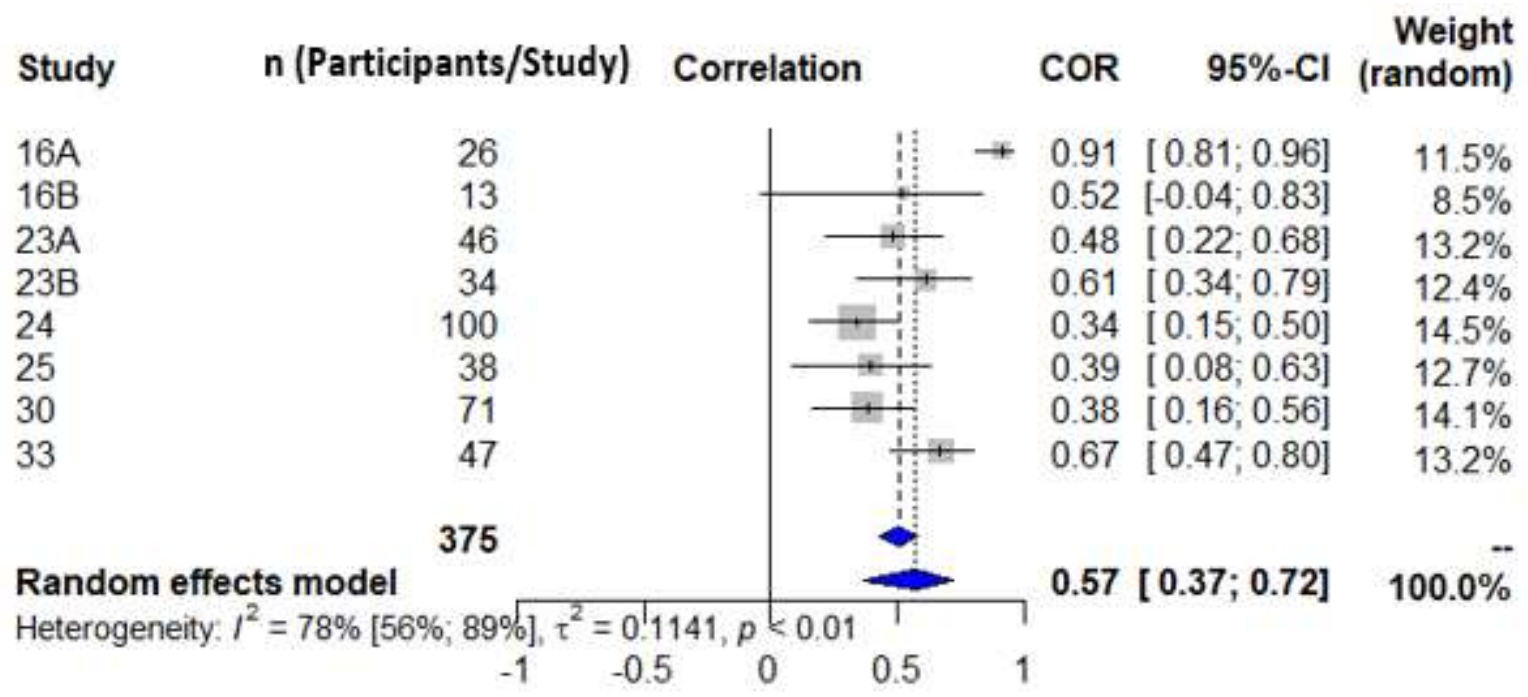


medRxiv preprint doi: https://doi.org/10.1101/2021.08.18.21262243; this version posted August 23, 2021. The copyright holder for this preprint (which was not certified by peer review) is the author/funder, who has granted medRxiv a license to display the preprint in perpetuity. It is made available under a CC-BY-NC-ND 4.0 International license.

\section{PRECURSORS OF BILINGUAL LITERACY DEVELOPMENT}

\section{Figure 8}

Meta-Analysis for Word/Non-Word Decoding in relation to Text Reading Comprehension. Forestplot indicating correlational effect size for random-effects model $(\mathrm{r}=0.6741 ; 95 \% \mathrm{CI}$ : $0.3705,0.8476 ; \mathrm{p}=0.0002)$ and individual correlations/study between word/non-word decoding and text reading comprehension.

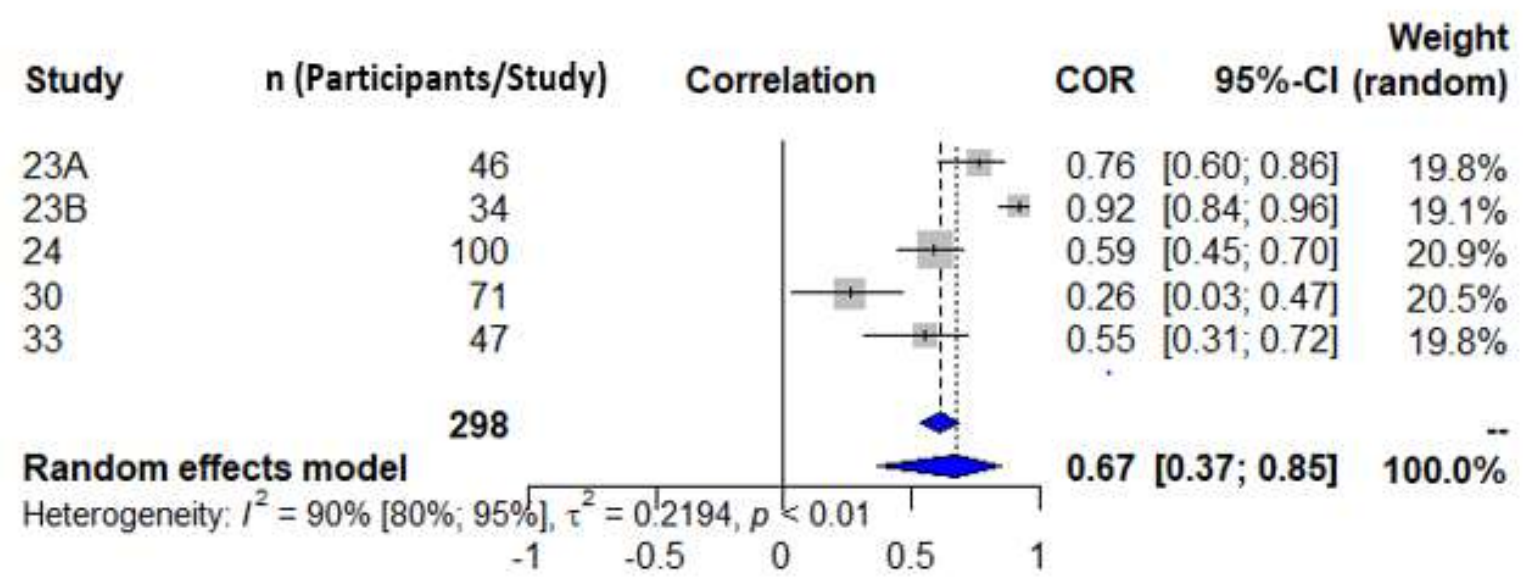


medRxiv preprint doi: https://doi.org/10.1101/2021.08.18.21262243; this version posted August 23, 2021. The copyright holder for this preprint (which was not certified by peer review) is the author/funder, who has granted medRxiv a license to display the preprint in perpetuity.

It is made available under a CC-BY-NC-ND 4.0 International license .

\section{PRECURSORS OF BILINGUAL LITERACY DEVELOPMENT}

\section{Figure 9}

Meta-Analysis for Phonological Awareness in relation to Word/Non-Word Reading, based on Type of Literacy Precursor and Outcome Measure Testing. Forestplot indicating correlational effect size for random-effects model ( $\mathrm{r}=0.4713 ; 95 \% \mathrm{CI}$ : 0.3850, 0.5494; $\mathrm{p}<0.0001)$ and individual correlations/study between phonological awareness and word/non-word reading, based on type of testing (i.e., whether phonological awareness and word/non-word reading measures were assessed in the same [within-language; $\mathrm{r}=0.5031 ; 95 \% \mathrm{CI}: 0.4098,0.5860$ ] or different [across-language; $r=0.3485 ; 95 \%$ CI: $0.1577,0.5142$ ] language; test for subgroup differences: $\mathrm{Q}=2.48 ; \mathrm{p}=0.1154)$.

\begin{tabular}{|c|c|c|c|c|c|c|}
\hline Study & n (Participants/Study) & alation & & COR & $95 \%-\mathrm{Cl}$ & Weight \\
\hline Testing & thin & & & & & \\
\hline $1 \mathrm{~A}$ & 20 & & $\mp-$ & 0.63 & {$[0.26 ; 0.84]$} & $3.0 \%$ \\
\hline $1 B$ & 33 & & 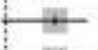 & 0.69 & {$[0.45 ; 0.84]$} & $4.1 \%$ \\
\hline $2 \mathrm{~A}$ & 29 & & 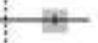 & 0.69 & {$[0.43 ; 0.84]$} & $3.9 \%$ \\
\hline 28 & 27 & & {$[-$} & 0.47 & {$[0.11 ; 0.72]$} & $3.7 \%$ \\
\hline $2 \mathrm{C}$ & 25 & & 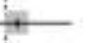 & 0.52 & {$[0.16 ; 0.76]$} & $3.5 \%$ \\
\hline $2 \mathrm{D}$ & 25 & & 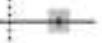 & 0.69 & {$[0.41 ; 0.85]$} & $3.5 \%$ \\
\hline 3 & 57 & It & - & 0.33 & {$[0.08 ; 0.54]$} & $5.2 \%$ \\
\hline 4 & 59 & m- & & 0.30 & {$[0.05 ; 0.52]$} & $5.3 \%$ \\
\hline $8 \mathrm{~A}$ & 311 & & + & 0.50 & {$[0.41 ; 0.58]$} & $7.2 \%$ \\
\hline $8 \mathrm{~B}$ & 147 & & & 0.45 & {$[0.31 ; 0.57]$} & $6.6 \%$ \\
\hline $8 \mathrm{C}$ & 163 & & 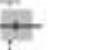 & 0.50 & {$[0.38 ; 0.61]$} & $6.7 \%$ \\
\hline 9 & 19 & & & 0.45 & {$[-0.01 ; 0.75]$} & $2.9 \%$ \\
\hline 15 & 9 & & $\star$ & 0.52 & {$[-0.22 ; 0.88]$} & $1.4 \%$ \\
\hline 22 & 74 & 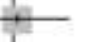 & & 0.02 & {$[-0.21 ; 0.25]$} & $5.7 \%$ \\
\hline $23 \mathrm{~A}$ & 46 & & 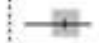 & 0.72 & {$[0.54 ; 0.84]$} & $4.8 \%$ \\
\hline $23 \mathrm{~B}$ & 34 & & 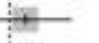 & 0.54 & {$[0.25 ; 0.74]$} & $4.2 \%$ \\
\hline 33 & 47 & & 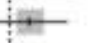 & 0.56 & {$[0.33 ; 0.73]$} & $4.9 \%$ \\
\hline Randor & ects model 1125 & & $\rightarrow$ & 0.50 & {$[0.41 ; 0.59]$} & $77.0 \%$ \\
\hline Heterogr & $r^{2}=59 \%[30 \% ; 78 \%], \tau^{2}=00346, p$ & $=0.01$ & & & & \\
\hline Testi & coss & & & & & \\
\hline $1 \mathrm{~A}$ & 20 & & $\approx$ & 0.57 & {$[0.17 ; 0.81]$} & $3.0 \%$ \\
\hline 1B & 33 & & $1+$ & 0.56 & {$[0.27 ; 0.76]$} & $4.1 \%$ \\
\hline 3 & 57 & It & & 0.18 & {$[-0.08 ; 0.42]$} & $5.2 \%$ \\
\hline 22 & 74 & 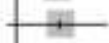 & & 0.20 & {$[-0.03 ; 0.41]$} & $5.7 \%$ \\
\hline & 47 & & & 0.35 & {$[0.07 ; 0.58]$} & $4.9 \%$ \\
\hline Randor & ects model 231 & $\Rightarrow$ & & 0.35 & {$[0.16 ; 0.51]$} & $23.0 \%$ \\
\hline Heterog: & $1^{2}=4216[096,78 \% 6], x^{2}=0.0288, p=$ & 0.14 & & & & \\
\hline Rando & cts model 1356 & & & 0.47 & {$[0.38 ; 0.55]$} & $100.0 \%$ \\
\hline Heterog & $I^{2}=60 \%[37 \% ; 75 \%], \tau^{2}=0.0370, p$ & & & & & \\
\hline & & & 0.5 & 1 & & \\
\hline
\end{tabular}


medRxiv preprint doi: https://doi.org/10.1101/2021.08.18.21262243; this version posted August 23, 2021. The copyright holder for this preprint (which was not certified by peer review) is the author/funder, who has granted medRxiv a license to display the preprint in perpetuity.

It is made available under a CC-BY-NC-ND 4.0 International license .

\section{PRECURSORS OF BILINGUAL LITERACY DEVELOPMENT}

\section{Figure 10}

Meta-Analysis for Phonological Awareness in relation to Word/Non-Word Reading, based on Type of Writing System. Forestplot indicating correlational effect size for random-effects model $(\mathrm{r}=0.5161 ; 95 \%$ CI: $0.4220,0.5992 ; \mathrm{p}<0.0001)$ and individual correlations/study between phonological awareness and word/non-word reading, based on type of writing system (i.e., whether simultaneous bilinguals, assessed on phonological awareness and word/non-word reading measures in an alphabetic language, spoke syllabic-alphabetic $[\mathrm{r}=0.5708 ; 95 \% \mathrm{CI}$ : $0.4813,0.6485]$ or alphabetic-alphabetic [r=0.3763; 95\% CI: $0.1781,0.5451]$ bilingual language combinations; test for subgroup differences: $\mathrm{Q}=3.97$; $\mathrm{p}=0.0463$ ).

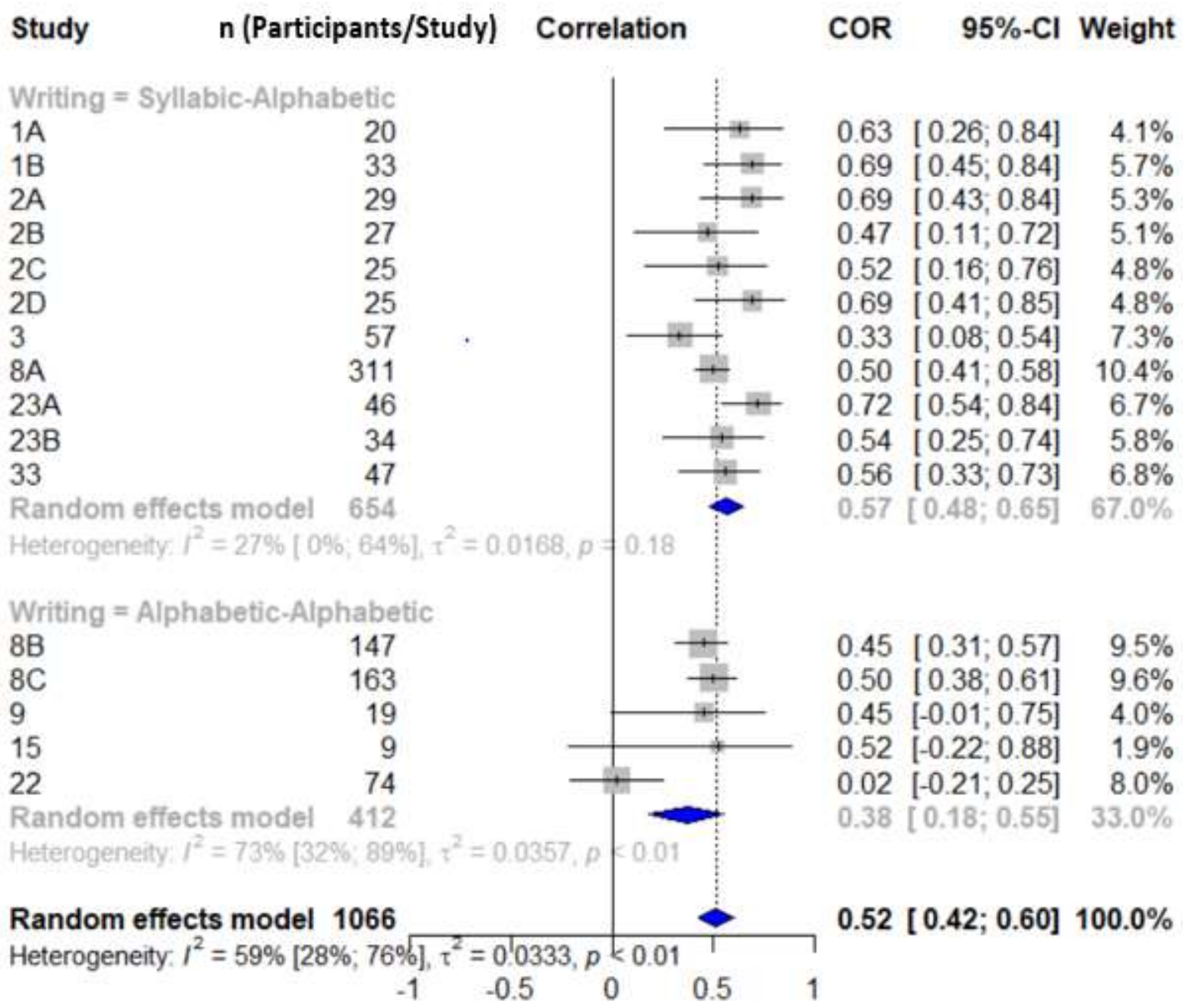


medRxiv preprint doi: https://doi.org/10.1101/2021.08.18.21262243; this version posted August 23, 2021. The copyright holder for this preprint (which was not certified by peer review) is the author/funder, who has granted medRxiv a license to display the preprint in perpetuity.

It is made available under a CC-BY-NC-ND 4.0 International license .

\section{PRECURSORS OF BILINGUAL LITERACY DEVELOPMENT}

\section{Figure 11}

Meta-Analysis for Phonological Awareness in relation to Word/Non-Word Reading, based on Country of Assessment. Forestplot indicating correlational effect size for random-effects model $(\mathrm{r}=0.5708 ; 95 \% \mathrm{CI}: 0.4813,0.6485 ; \mathrm{p}<0.0001)$ and individual correlations/study between phonological awareness and word/non-word reading, based on country of assessment (i.e., whether Chinese-English simultaneous bilinguals were assessed, on English phonological awareness and word/non-word reading measures, in Canada/US [ $\mathrm{r}=0.5813 ; 95 \% \mathrm{CI}$ : 0.4453 , $0.6910]$ or Singapore [ $r=0.5553 ; 95 \%$ CI: $0.4322,0.6581]$; test for subgroup differences: $\mathrm{Q}=0.09 ; \mathrm{p}=0.7610$ ).

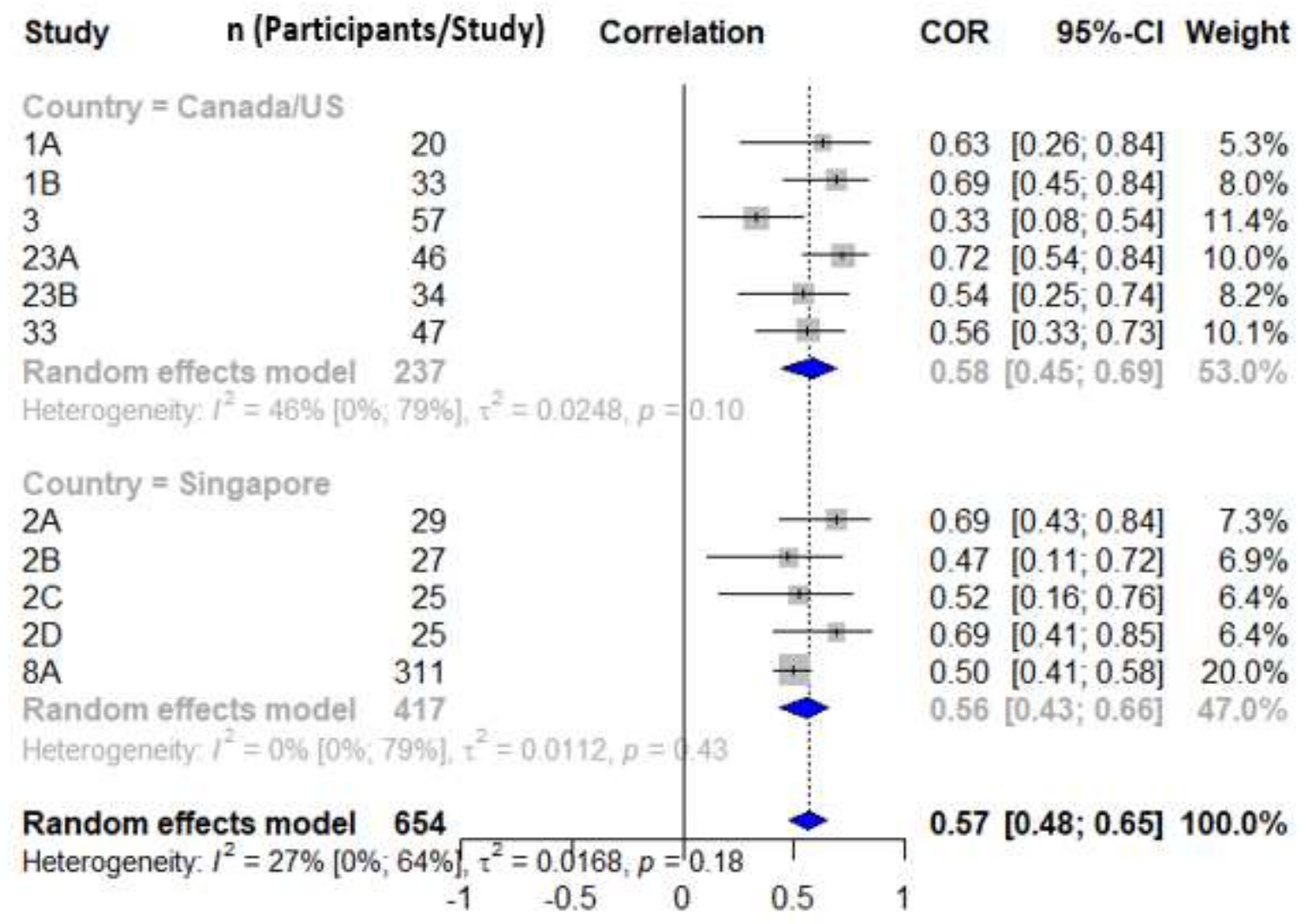


medRxiv preprint doi: https://doi.org/10.1101/2021.08.18.21262243; this version posted August 23, 2021. The copyright holder for this preprint (which was not certified by peer review) is the author/funder, who has granted medRxiv a license to display the preprint in perpetuity.

It is made available under a CC-BY-NC-ND 4.0 International license .

\section{PRECURSORS OF BILINGUAL LITERACY DEVELOPMENT}

\section{Figure 12}

Meta-Analysis for Vocabulary in relation to Word/Non-Word Reading, based on Type of Literacy Precursor and Outcome Measure Testing. Forestplot indicating correlational effect size for random-effects model ( $\mathrm{r}=0.3254 ; 95 \% \mathrm{CI}$ : 0.2135, 0.4289; $\mathrm{p}<0.0001)$ and individual correlations/study between vocabulary and word/non-word reading, based on type of testing (i.e., whether vocabulary and word/non-word reading measures were assessed in the same [withinlanguage; $r=0.4221 ; 95 \% \mathrm{CI}: 0.28889,0.5392$ ] or different [across-language; $r=0.2026 ; 95 \%$ CI: 0.0644, 0.3332] language; test for subgroup differences: $Q=5.32 ; p=0.0210$ ).

\section{Study}

Testing = Within

$1 \mathrm{~A}$

$1 \mathrm{~B}$

3

$16 \mathrm{~A}$

$16 \mathrm{~B}$

22

$23 \mathrm{~A}$

23B

25

30

33

Random effects model

Heterogeneity: $I^{2}=54 \%[9 \% ; 77 \%$ ]

\section{Testing $=$ Across}

3

$8 \mathrm{~A}$

$8 B$

$8 \mathrm{C}$

22

30

33

Random effects model Heterogeneity: $I^{2}=58 \%[4 \% ; 82 \%], \tau^{2}=0.0250, p$

Random effects model 1329

\section{n (Participants/Study) Correlation}

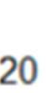

33

57

26

13

74

46

34

38

71

47

459

Heterogeneity: $I^{2}=64 \%[40 \% ; 78 \%]$

$-1 \quad-0.5$

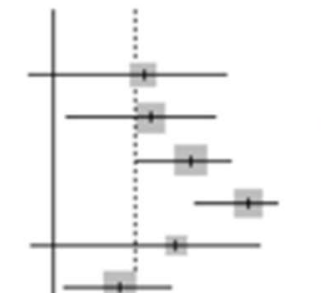

$0.36[-0.10 ; 0.69] \quad 3.6 \%$

$0.39[0.05 ; 0.65] \quad 4.8 \%$

$0.55[0.34 ; 0.71] \quad 5.8 \%$

$0.78[0.56 ; 0.90] \quad 4.2 \%$

$0.49[-0.08 ; 0.82] \quad 2.6 \%$

$0.27[0.04 ; 0.47] \quad 6.3 \%$

$0.44[0.17 ; 0.65] \quad 5.4 \%$

$0.50 \quad[0.19 ; 0.72] \quad 4.8 \%$

$0.32[0.00 ; 0.58] \quad 5.1 \%$

$0.08[-0.16 ; 0.31] \quad 6.2 \%$

$0.46[0.20 ; 0.66] \quad 5.5 \%$

$0.42[0.29 ; 0.54] \quad 54.3 \%$

$0.06[-0.20 ; 0.32] \quad 5.8 \%$

$0.20[0.09 ; 0.30] \quad 7.6 \%$

$0.33[0.18 ; 0.47] \quad 7.1 \%$

$0.20[0.05 ; 0.34] \quad 7.2 \%$

$0.46[0.26 ; 0.62] \quad 6.3 \%$

$0.14[-0.10 ; 0.36] \quad 6.2 \%$

$-0.11[-0.39 ; 0.18] \quad 5.5 \%$

$0.20[0.06 ; 0.33] \quad 45.7 \%$

$0.33[0.21 ; 0.43] 100.0 \%$ 
medRxiv preprint doi: https://doi.org/10.1101/2021.08.18.21262243; this version posted August 23, 2021. The copyright holder for this preprint

(which was not certified by peer review) is the author/funder, who has granted medRxiv a license to display the preprint in perpetuity.

It is made available under a CC-BY-NC-ND 4.0 International license .

\section{PRECURSORS OF BILINGUAL LITERACY DEVELOPMENT}

\section{Files}

\section{Supplemental File 1: Database Search Syntax}

Note: For purposes of our database search, ' $O R$ ' is used to specify terms that are optional or alternatives for a specified term while ' $A N D$ ' specifies terms that are mandatory.

\section{Database Search of the 8 Literacy Precursors (in Relation to Word/Non-Word Decoding or Reading)}

(Phonological Awareness $O R$ phonem* awareness $O R$ letter knowledge $O R$ grapheme knowledge $O R$ Grapheme Phoneme Correspondence $O R$ sound symbol* $O R$ Serial Recall $O R$ Oral Comprehension $O R$ Verbal Comprehension $O R$ Listening Comprehension $O R$ Vocabulary $O R$ Word Knowledge OR grammar OR Syntax OR Syntac* OR Synta* OR Morpholog* OR Morphem* $O$ $R$ Visual Short Term Memory $O R$ Phonological Short Term Memory $O R$ Short Term Memory $O R$ Working Memory $O R$ Visual Memory $O R$ Verbal Memory $O R$ Nonverbal Memory $O R$ Nonverbal Ability $O R$ Nonverbal Intelligence $O R$ Nonverbal IQ) $A N D$ (Word Decoding $O R$ Reading Fluency $O R$ Word Recognition $O R$ Reading Ability $O R$ Reading Skills $O R$ Literacy Skills) $A N D$ (mainsubject(Child*) $O R$ mainsubject(Infants)) $A N D$ (mainsubject(Bilingual*) $O R$ mainsubject(Multilingual*) $O R$ mainsubject(Second Language Learner*))

\section{Database Search of the 9 Literacy Precursors (in Relation to Reading Comprehension)}

(Phonological Awareness $O R$ phonem* awareness $O R$ letter knowledge $O R$ grapheme knowledge $O R$ Grapheme Phoneme Correspondence $O R$ sound symbol* $O R$ Serial Recall $O R$ Oral Comprehension $O R$ Verbal Comprehension $O R$ Listening Comprehension $O R$ Vocabulary $O R$ Word Knowledge OR grammar OR Syntax OR Syntac* OR Synta* OR Morpholog* OR Morphem* $O$ $R$ Visual Short Term Memory $O R$ Phonological Short Term Memory $O R$ Short Term Memory $O R$ Working Memory $O R$ Visual Memory $O R$ Verbal Memory $O R$ Nonverbal Memory $O R$ Nonverbal Ability $O R$ Nonverbal Intelligence $O R$ Nonverbal IQ $O R$ Word Decoding $O R$ Reading Fluency $O R$ Word Recognition $O R$ Reading Ability $O R$ Reading Skills OR Literacy Skills) $A N D$ (Reading Comprehension) $A N D$ (mainsubject(Child*) $O R$ mainsubject(Infants)) AND (mainsubject(Biling

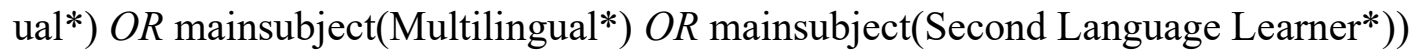

\section{Database Search of General Literacy Precursors (in Relation to Word/Non-Word Decoding or Reading)}

(Precursor Literacy $O R$ Precursor Reading $O R$ Predictor Literacy $O R$ Predictor Reading $O R$ Precursor Literacy Skills $O R$ Precursors of Reading Ability $O R$ Early Predictors of 
medRxiv preprint doi: https://doi.org/10.1101/2021.08.18.21262243; this version posted August 23, 2021. The copyright holder for this preprint (which was not certified by peer review) is the author/funder, who has granted medRxiv a license to display the preprint in perpetuity. It is made available under a CC-BY-NC-ND 4.0 International license.

\section{PRECURSORS OF BILINGUAL LITERACY DEVELOPMENT}

Later Conventional Literacy Skills $O R$ Predictive Literacy Skills $O R$ Predictors of Later Reading Skills $O R$ Preschool Literacy) $A N D$ (Word Decoding $O R$ Reading Fluency $O R$ Word Recognition $O R$ Reading Ability $O R$ Reading Skills $O R$ Literacy Skills) $A N D$ (mainsubject(Child*) $O R$ mainsubject(Infants)) $A N D$ (mainsubject(Bilingual*) $O R$ mainsubject(Multilingual*) OR mainsubject(Second Language Learner*))

Database Search of General Literacy Precursors (in Relation to Reading Comprehension) (Precursor Literacy $O R$ Precursor Reading $O R$ Predictor Literacy $O R$ Predictor Reading $O R$ Precursor Literacy Skills $O R$ Precursors of Reading Ability $O R$ Early Predictors of Later Conventional Literacy Skills $O R$ Predictive Literacy Skills $O R$ Predictors of Later Reading Skills $O R$ Preschool Literacy) $A N D$ (Reading

Comprehension) $A N D$ (mainsubject(Child*) OR mainsubject(Infants)) $A N D$ (mainsubject(Biling ual*) $O R$ mainsubject(Multilingual*) $O R$ mainsubject(Second Language Learner*)) 